\title{
Lund Easement Baseline Biological Inventory
}

Prepared for:

The Natural Resource Conservation Service

By:

Catherine Jean and Paul Hendricks

Montana Natural Heritage Program

Natural Resource Information System

Montana State Library

September 2001

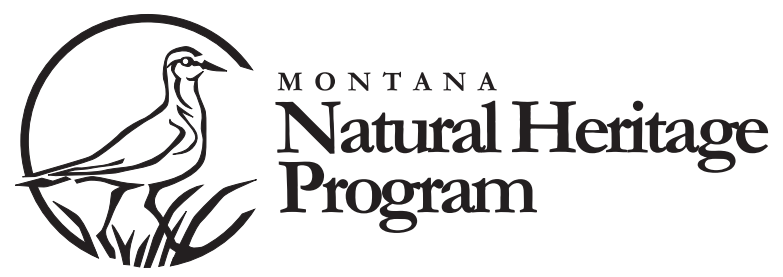




\section{Lund Easement Baseline Biological Inventory}

Prepared for:

The Natural Resource Conservation Service

By:

Catherine Jean and Paul Hendricks
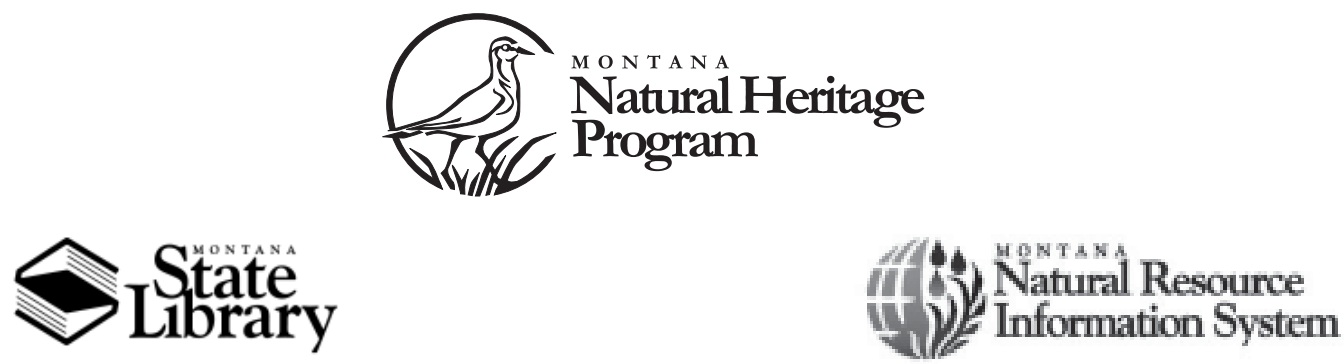

(c) 2001 Montana Natural Heritage Program

P.O. Box 201800 • 1515 East Sixth Avenue • Helena, MT 59620-1800 • 406-444-5354 
The preferred citation for this document is:

Jean, C. and P. Hendricks. 2001. Lund Easement Basline Biological Inventory. Report for the Natural Resource Conservation Service. Montana Natural Heritage Program, Helena, MT. 16 pp. + appendices. 


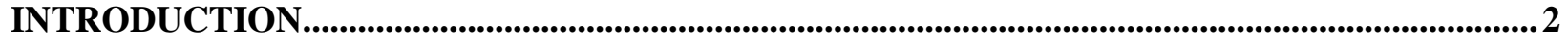

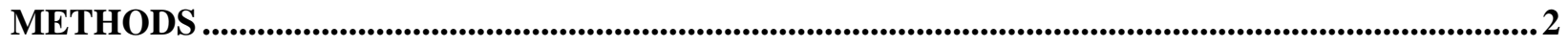

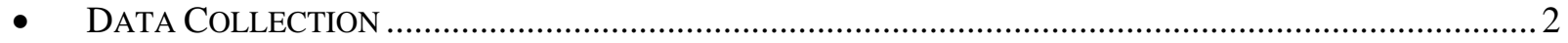

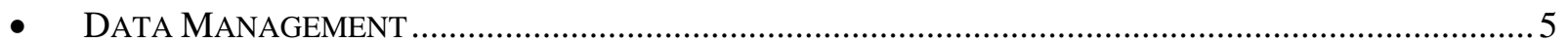

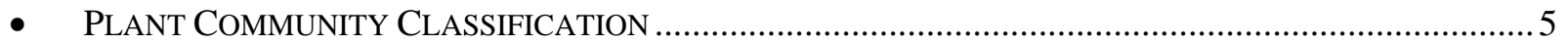

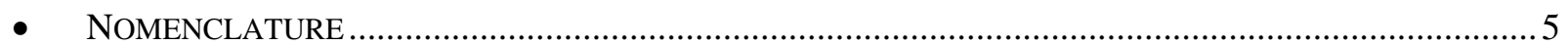

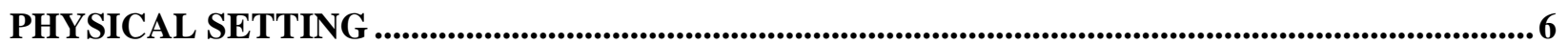

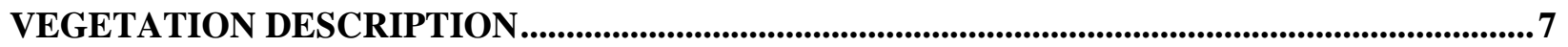

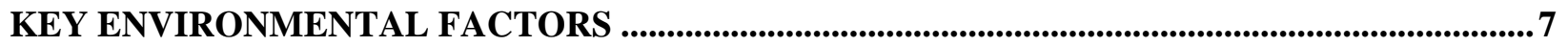

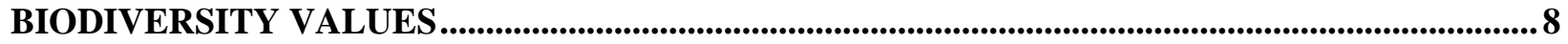

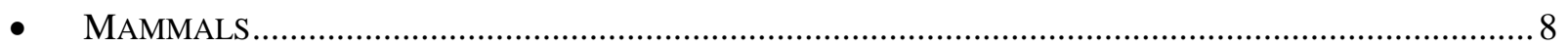

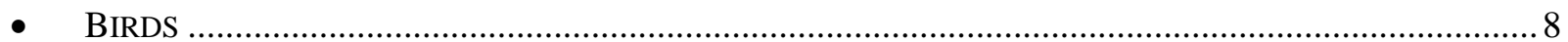

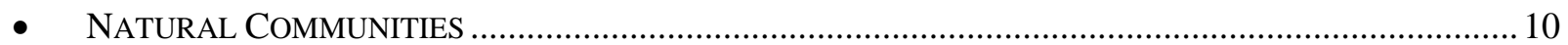

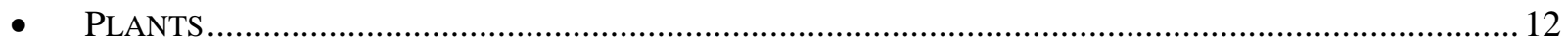

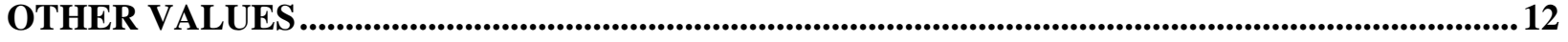

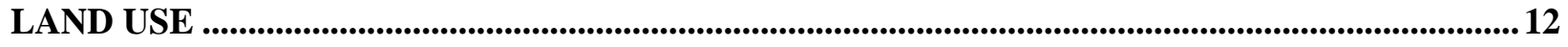

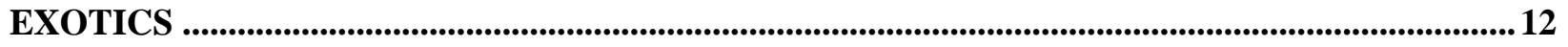

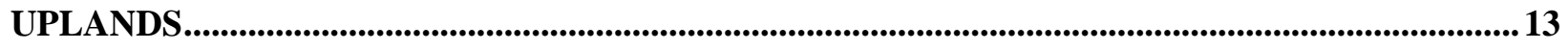

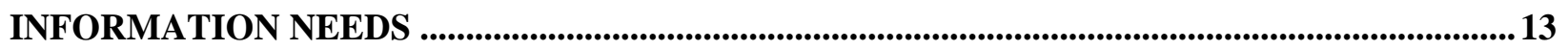

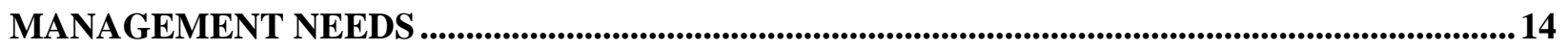

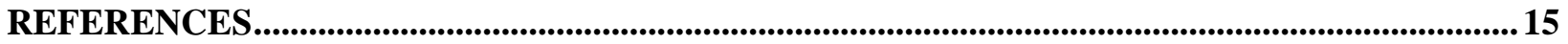




\section{INTRODUCTION}

The Lund property is part of the Prairie Pothole region of Montana, an area encompassing one of largest mixed-grass prairie and wetland complexes remaining in the Northern Great Plains. This region has high biodiversity values and is considered a focal area for wetland and prairie grassland protection and restoration by the Fish and Wildlife Service (FWS, 2001) and in Canada, the Alberta Conservation Data Center recognizes Sage Creek watershed as nationally significant (TNC, 1999). Conservation initiatives are increasingly used to help maintain these important habitats for plant and animal species.

In the United States, the Wetlands Reserve Program (WRP) provides private landowners financial incentives to voluntarily retire marginal agricultural land by placing property under conservation easement. The Lund property has a valuable mix of grassland and wetland vegetation and was placed under easement with the Natural Resource Conservation Service (NRCS) for the purpose of wetland restoration and enhancement.

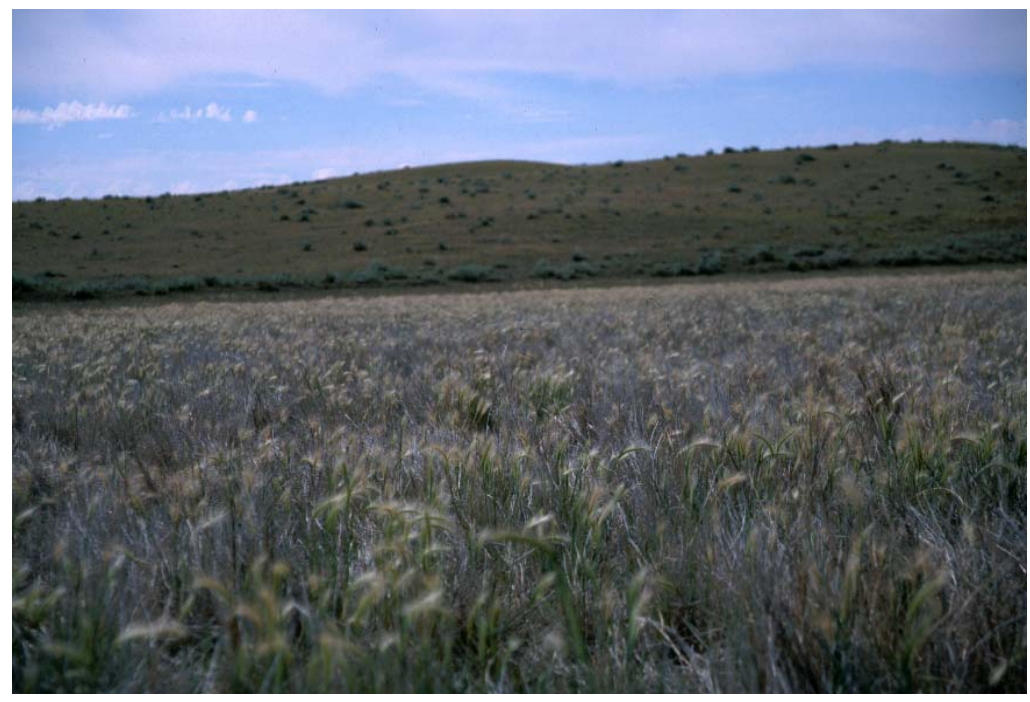

A portion of the easement, on what is known as Wild Horse Lake, was highly modified in the past with dikes and ditches constructed to drain natural hay meadows. NRCS is working together with the landowner on a wetland restoration project that is aimed at reclaiming and restoring a portion of the prairie wetland. This WRP project represents an important effort to restore biological diversity to the Prairie Pothole region in Montana by restoring this grassland-wetland ecosystem.

Foxtail Barley

\section{METHODS}

The goal of this project was to compile baseline biological information on the Lund Easement to build a scientific foundation for ecosystem monitoring and assessment and to inform wetland restoration and management plans. Inventories were conducted to gather basic information about key biological resources including presence or absence of plant and animal species of concern and other noteworthy observations. Natural plant communities were sampled and described with emphasis upon those that exemplify the Montana Glaciated Plains landscape.

\section{- Data Collection}

Plant and natural community surveys were conducted during the summer of 2000 and mammal and bird surveys took place on 18-20 July in 2000 and 26-28 May in 2001. Our inventory was designed to systematically inventory and evaluate the distribution, habitats and status of the biological resources on the Lund Easement. We started by searching the Heritage element occurrence database and checking available literature to identify potential target plant and animal Species of Concern (Carlson, 2001 and Heidel, 2001) with habitat in the Wild Horse Lake area. Inventories for several plant species of concern associated with wet or vernally moist areas were cancelled due to extreme drought in 2000 and 2001. 
Figure 1. Lund Easement Study Area

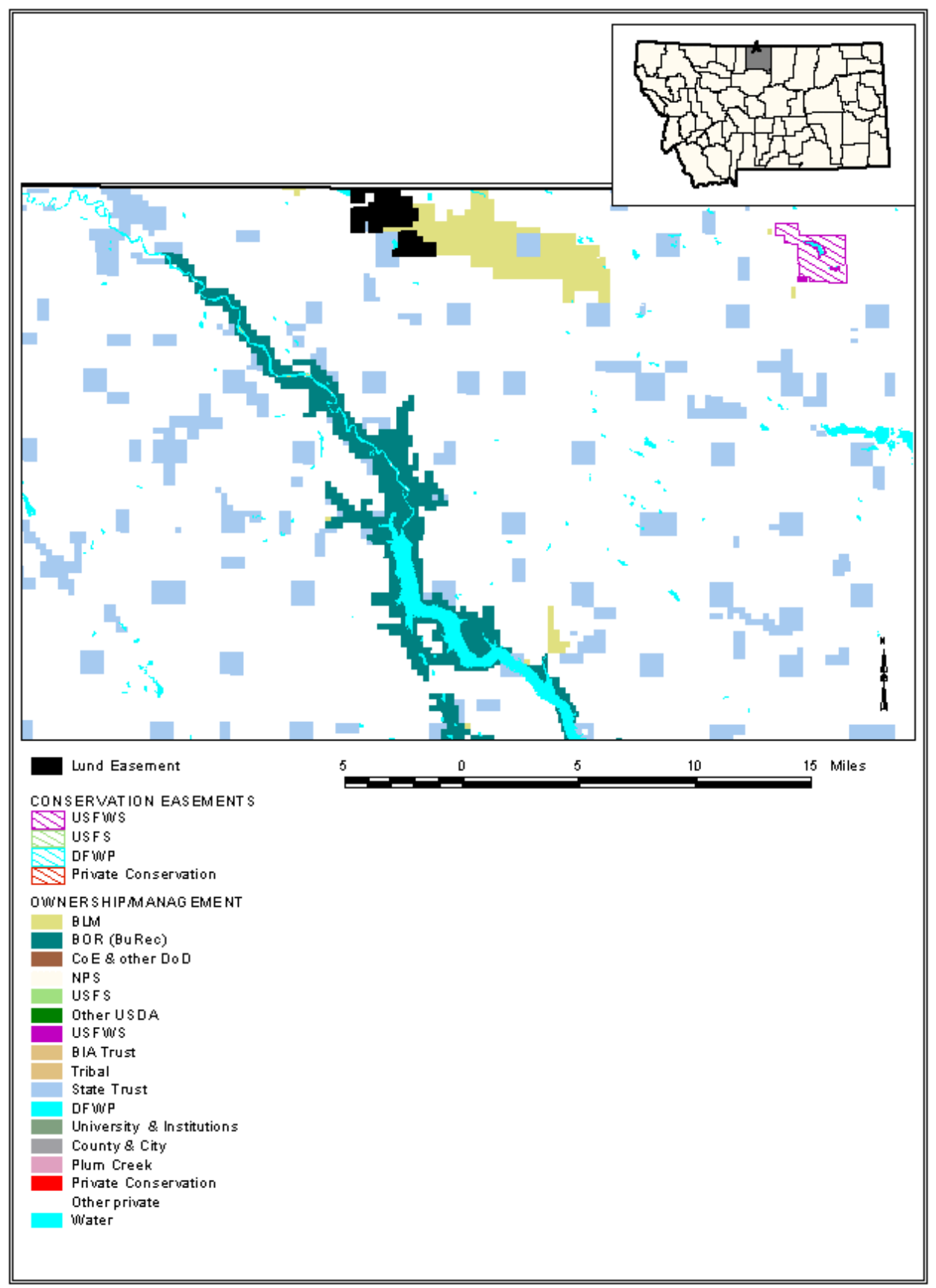


In the Field, plant associations were recorded using a Rapid Ecological Assessment (REA) technique to characterize the vegetation across the landscape catena. With this technique, composition and cover of dominant species are recorded for all communities across environmental gradients. The REA technique is favored where the vegetation community has already been classification and described and, documentation within a project areas is the principle objective. Circular $1 / 10$-acre vegetation plots were established in stands with homogeneous vegetation and uniform environmental conditions. We recorded vegetation structure and floristic composition, plot location and environmental data, and made comments on disturbance evidence, exotic species and community size condition and landscape context.

Due to limited field time, and the relatively small study area, we documented birds as they were encountered by traversing daily as much of the study area as possible, both via vehicle and on foot. This sampling approach generated a species list, with associated evidence of breeding status, but was not designed to document relative abundance (Bibby et al, 2000). Efforts to locate wetland-related bird species were largely thwarted due to drought conditions both years and extremely limited availability of surface water. However, we visited stock ponds and tanks to document transient wetland species. Dry lakebeds and native upland grassland with ground squirrel activity and sparse vegetation were scanned daily for Burrowing Owl and Mountain Plover, using a 60X spotting scope. We inspected all windbreaks, isolated stands of trees, and abandoned buildings for active nests of raptors and other species.

Large and medium-sized mammals were documented whenever encountered, but we made no attempt to sample them systematically. We trapped small mammals in both years. Traps were distributed along trap lines consisting of 10 trap-stations/line. In 2000 we placed one Sherman live trap at each station and one museum special snap trap at alternate stations on each line. In 2001 we placed a single live trap at each station on all lines. Trap stations were 20 paces (about $20 \mathrm{~m}$ ) apart. Live traps were baited with rolled oats, snap traps with peanut butter. We ran six lines (1-6) for a single night in July 2000 and six more (712) for a single night in May 2001 (see Figure 2, Table 1). Lines 1, 4, and 12 were in upland short-grass habitat; lines 2, 3, 7, and 9 were in stands of lakebed-margin sagebrush; lines 5, 6, 10, and 11 were in lakebed depression "grassland"; line 8 was along a fence row in mixed cropland of wheat and crested wheatgrass stubble with sandy soil.

Table 1. Small mammals captured on 12 trap lines in the Wild Horse Lake study area, Hill County, Montana. Lines 1-6 were trapped the night of 19 July 2000; Lines 7-12 were trapped the night of 27 May 2001

Line 1 (T37N R12E Sec. 15SWSW)

Line 2 (T37N R12E Sec. 16NESE)

Line 3 (T37N R12E Sec. 9SWSW)

Line 4 (T37N R12E Sec. 8SESW)

Line 5 (T37N R12E Sec. 9NWSE)

Line 6 (T37N R12E Sec. 9NESW)

Line 7 (T37N R12E Sec. 9SWSW)

Line 8 (T37N R12E Sec. 14NWNW)

Line 9 (T37N R12E Sec. 8SENE)

Line 10 (T37N R12E Sec. 9NWSW)

Line 11 (T37N R12E Sec. 4NWNW)

Line 12 (T37N R12E Sec. 8SWSW) no captures

Deer Mouse (4)

Deer Mouse (4), Northern Grasshopper Mouse (1)

no captures

no captures

no captures

Deer Mouse (3), Richardson's Ground Squirrel (2)

Olive-backed Pocket Mouse (1)

Deer Mouse (2)

Deer Mouse (2)

Deer Mouse (1)

Deer Mouse (2)

Deer Mouse = Peromyscus maniculatus; Northern Grasshopper Mouse = Onychomys leucogaster; Olivebacked Pocket Mouse = Perognathus fasciatus; Richardson's Ground Squirrel $=$ Speromophilus richarsonii

We also inspected fence lines for raptor pellets; collected pellets were dissected for mammal skull fragments. We based species determinations of all trapped mammals and recovered skull fragments on external and skull characteristics described in Foresman (2001b). 


\section{- Data Management}

Community ecology plots were located and recorded with a Global Positioning System (GPS) and later uploaded into a Geographic Information System (GIS). All plot data were transcribed to a computerized database for analysis and permanent storage in Heritage data system. Vegetation maps were digitized using ArcView edit and saved as a shapefile. Digital Orthophotos and USGS Quad maps in Digital Raster Graphic formats were used to digitize vegetation boundaries; community ecology plots were used to identify the vegetation type. The minimum map unit is aproximately10 acres, leaving many small patch or linear communities unmapped e.g. common spike rush (Eleocharis palustris) within linear sloughs.

Community and bird element occurrence data were geo-referenced, digitized and incorporated into the Montana Natural Heritage Program data system. Nest and small mammal trap locations were digitized from latitude and longitude coordinates obtained from 1:24,000 quad maps.

\section{- Plant Community Classification}

Species composition and cover for each plot was compared to existing classification schemes to determine the community type assignment. Plot assignments to plant association are also evaluated in terms of abiotic site descriptors. We organized our findings within the International Vegetation Classification System (ABI, 2000). The classification is hierarchical and combines floristics at the lowest levels (associations and alliances) and structure (physiognomy) and overarching climate conditions at the highest levels. The Federal Geographic Data Committee (FGDC, 1997) has approved the upper levels of the hierarchy as a classification standard. In this report, the plant association is defined in terms of the dominant species of the uppermost vegetation layer, and any co-dominant species or diagnostic species in the same strata separated with a dash; understory species are separated with a slash.

\section{- Nomenclature}

The principal floristic references for plant identification are "Flora of the Great Plains" (The Great Plains Flora Association, (1977, 1986)), "Vascular Plants of Montana" (Dorn, 1984) and "Flora of the Pacific Northwest” (Hitchcock and Cronquist, 1973). Plant nomenclature follows Kartesz (1999); as a consequence, recent taxonomic revisions to the wheat-grass tribe (Elymus and Agropyron) have resulted in new names for once familiar sounding scientific names. Thus western wheatgrass (Agropyron smithii) in Booth (1950) and Hitchcock and Cronquist (1973) and Elymus smithii in Dorn (1984) is now referenced as Pascopyrum smithii. Synonymy of dominant and indicator plants used in plant association names is presented in Table 2.

Common and scientific names of birds and mammals follow the "Checklist of North American Birds, $7^{\text {th }}$ edition” (American Ornithologists' Union, 1998) and “The wild mammals of Montana” (Foresman, 2001a), respectively. 
Table 2. Synonymy of dominant and indicator plants on the Lund Easement

\begin{tabular}{|l|l|l|l|}
\hline \multicolumn{1}{|c|}{ Common name } & $\begin{array}{l}\text { In: Booth (1950), (1966) or } \\
\text { Great Plains Flora Assoc. } \\
(1986)\end{array}$ & In: Dorn (1984) & In: Kartesz (1999) \\
\hline \hline Thickspike wheatgrass & Agropyron dasystachyum & Elymus lanceolatus & Elymus lanceolatus \\
\hline Western wheatgrass & Agropyron smithii & Elymus smithii & Pascopyrum smithii \\
\hline Bluebunch wheatgrass & Agropyron spicatum & Elymus spicatus & Pseudoroegneria spicata \\
\hline Green needlegrass & Stipa viridula & Stipa viridula & Nassella viridula \\
\hline Needle-and-thread grass & Stipa comata & Stipa comata & Hesperostipa comata \\
\hline Sandberg's Bluegrass & Poa juncifolia & Poa juncifolia & Poa secunda \\
\hline
\end{tabular}

\section{PHYSICAL SETTING}

The Lund Easement is located 40 miles northwest of Havre at the western end of Wild Horse Lake, a giant depressional wetland associated with the temporarily flooded lake basin (Figure 1). The lake and surrounding lands are part of the Prairie Pothole region of Montana: wetlands typically associated with a wide range of diversity in plant, animal and aquatic life. The easement property consists of approximately 3,212 acres, largely within the historic lakebed on the north and east and to the south, uplands along Spring Coulee Ridge.

A few pothole depressions are scattered throughout the easement. The lake bottom is an extensive flat closed basin with areas of large unvegetated mud flats. During periods of high precipitation and snowmelt, surface water from the north drains into the basin and the lake fills to form an ephemeral, or vernal lake. Sage Creek, drains into Wild Horse Lake from the northwest.

The rolling to flat topography provides elevation ranges from 2790 feet in the lakebed to 2871 feet on a low ridge to the south and 2886 feet

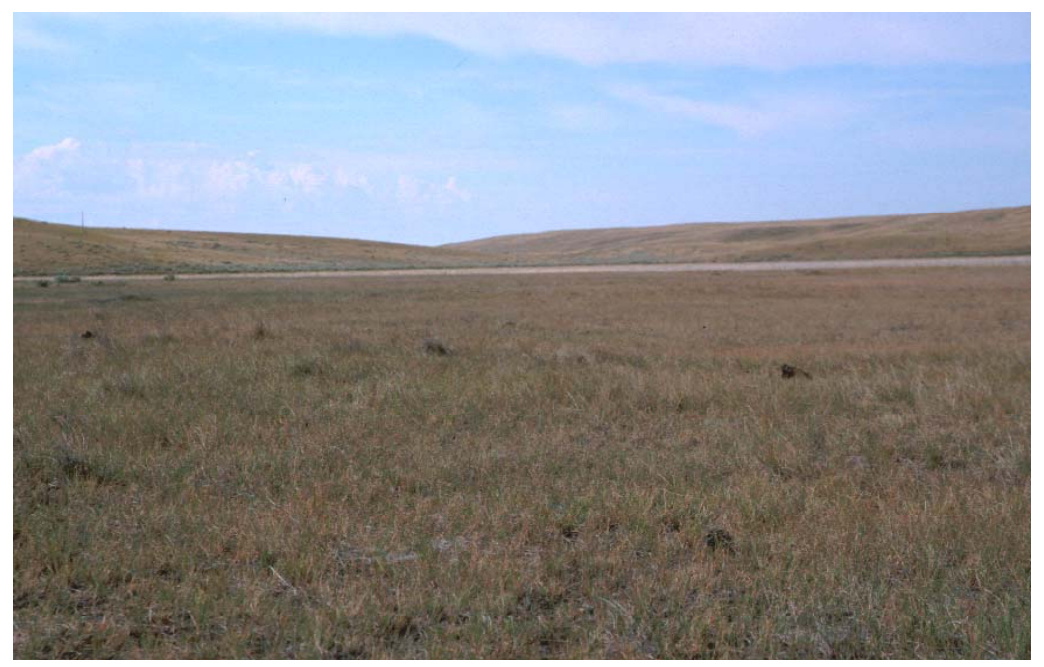

Western Wheatgrass on the Spring Coulee Ridge to the west. Soils are of the Cretaceous Montana Group and were deposited 83 to 64 million years ago when two Cretaceous seas retreated (Veseth and Montagne, 1980). Drainage is poor to moderate on flat sites. Fine-to medium textured soils derived from alluvium, with shale, clay, mudstone and siltstone interspersed throughout, support a wide range of grasses, sedges and shrubs (Veseth and Montagne, 1980).

Over a forty-year period, mean temperatures ranged from 14 degrees in January to 70 degrees in August. The area receives an average of 10 to 15 inches of precipitation a year with $20 \%$-30\% as snow (Nesser et al, 1997). 


\section{VEGETATION DESCRIPTION}

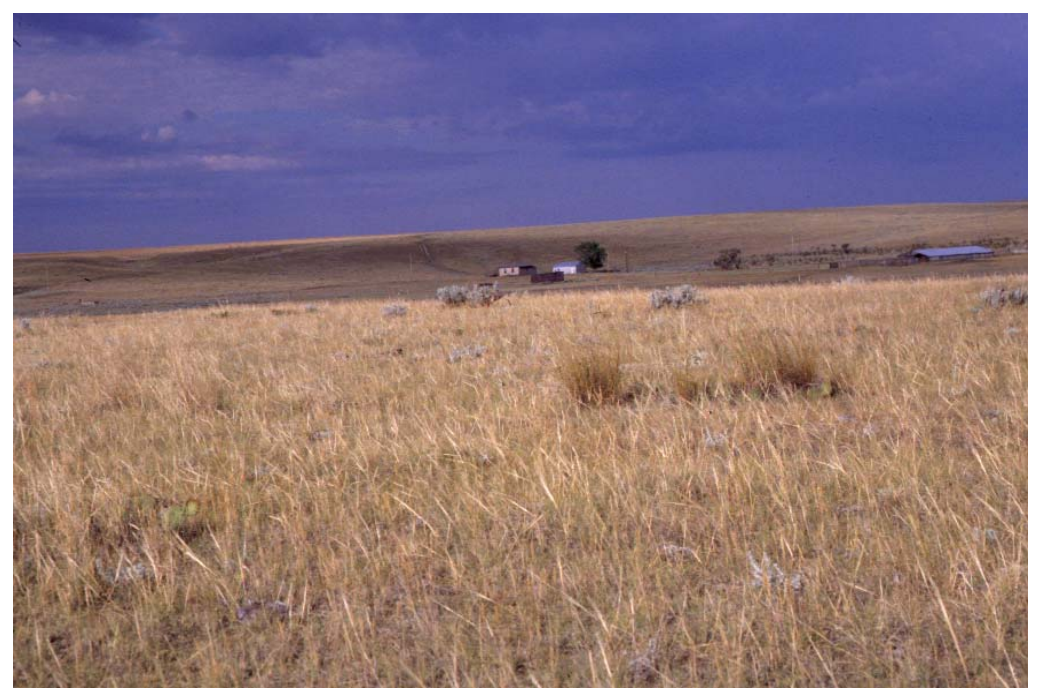

Needle-and Thread - Blue Grama - Thread-leaved sedge
The vegetation on the Lund

Easement is characteristic of the Montana Glaciated Plains landscape. The uplands, which are largely sandy and thin silty ecological sites, are dominated by Needle-and-Thread Blue Grama Herbaceous Vegetation (Stipa comata - Bouteloua gracilis Carex filifolia). Two short grass species, thread-leaved sedge (Carex filifolia) and Sandberg's bluegrass (Poa secunda) switch in understory dominance throughout this type. Patches of Prairie Sandreed - Sedge Prairie Herbaceous Vegetation (Calamovilfa longifolia - Carex inops spp. heliophilia) occur on sandy upper-slope positions. Isolated potholes have higher clay content and

contain one or a combination of western wheatgrass (Pascopyrum smithii), common spike rush (Eleocharis palustris), or clustered field sedge (Carex praegracilis) Herbaceous Vegetation communities. The lake basin experiences flooding during extremely wet years leaving extensive areas of sparsely vegetated mud flats. Black Greasewood / Western Wheatgrass - Shrub Herbaceous Vegetation (Sarcobatus vermiculatus / Pascopyrum smithii) forms an extensive shrub community in the Wild Horse Lake basin. On the Lund Easement, western wheatgrass is by far the dominant natural community and grows as a near monoculture over hundreds of acres.

The lakebed is periodically interrupted by sloughs, old overflow or stream meanders, that contain linear patches of common spike rush. The wettest location

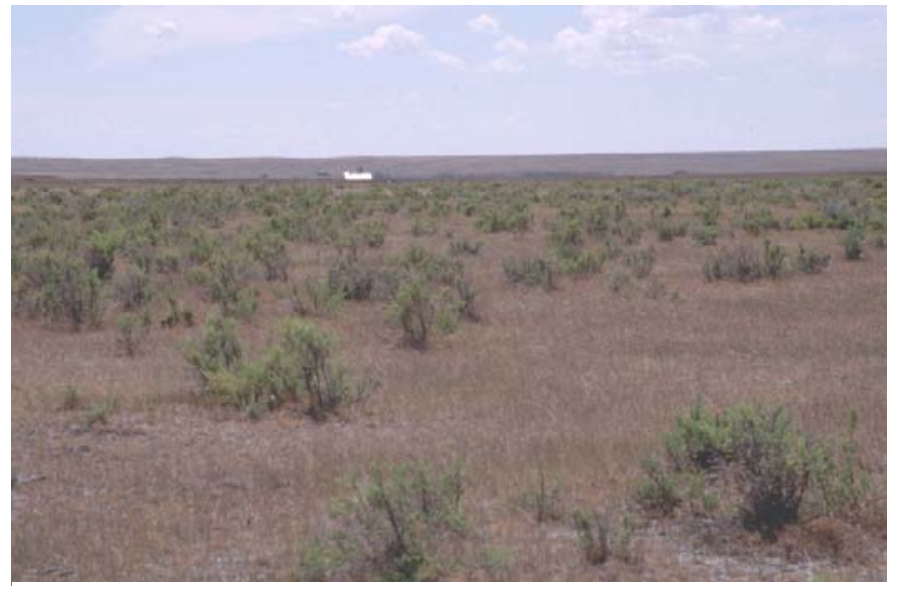

Black Greasewood / Western Wheatgrass on the easement is located along the northern boarder with Canada; this wetland includes a tufted hairgrass (Deschampsia cespitosa) Herbaceous community.

\section{KEY ENVIRONMENTAL FACTORS}

Wild Horse is an extensive closed lake basin. During periods of high precipitation and show melt, surface water from the north drains into the basin; when water is abundant, the lake fills to form an ephemeral, or vernal lake. Wetlands and associated obligate wetland vascular species are associated with Grassy Lake, Sage Creek and it's tributaries as well as overflow ditches and culverts placed to drain meadows during periods of excess water.

The region experiences extremes in drought and flooding. 


\section{BIODIVERSITY VALUES}

\section{- Mammals}

We detected 10 mammal species during our inventory (Table 3). Another species, Sagebrush Vole, was reported by Dennis Flath (personal communication). None are state Species of Concern (Carlson, 2001), but Pygmy Shrew (Sorex hoyi) is a state Species on Review requiring more data to determine its status. A partial skull of a Pygmy Shrew was found with remains of a Meadow Vole (Microtus pennsylvanicus) in an old raptor pellet below a fence line in Section 8. The record represents a range extension of over $300 \mathrm{~km}$ E in Montana, as well as a record filling a large northward hiatus into Canada between the Rocky Mountains to the west and North Dakota and Saskatchewan to the east and northeast (Hendricks 2001). The shrew may have been carried into the Lund Easement from one of the montane uplands (Sweet Grass Hills, Bears Paw Mountains, Cypress Hills), as this species is most often found in dry conifer forest (Foresman 2001a).

Table 3. Mammals detected in the Wild Horse Lake study area. Documentation codes following species names are sight record $(\mathrm{S})$, capture record $(\mathrm{C})$, or remains $(\mathrm{R})$

$\begin{array}{ll}\text { Pygmy Shrew (Sorex hoyi) } & \mathrm{R} \\ \text { White-tailed Jackrabbit (Lepus townsendii) } & \mathrm{S} \\ \text { Mountain Cottontail (Sylvilagus nuttallii) } & \mathrm{S} \\ \text { Olive-backed Pocket Mouse (Perognathus fasciatus) } & \mathrm{C} \\ \text { Sagebrush Vole (Lemmiscus curtatus) } & \mathrm{C} \text { (D. Flath pers. comm.) } \\ \text { Meadow Vole (Microtus pennsylvanicus) } & \mathrm{R} \\ \text { Northern Grasshopper Mouse (Onychomys leucogaster) } & \mathrm{C} \\ \text { Deer Mouse (Peromyscus maniculatus) } & \mathrm{C}, \mathrm{R} \\ \text { Richardson's Ground Squirrel (Spermophilus richarsonii) } & \mathrm{S}, \mathrm{C} \\ \text { Coyote (Canis latrans) } & \mathrm{S}, \mathrm{R} \\ \text { Pronghorn (Antilocapra americana) } & \mathrm{S}\end{array}$

We trapped 22 individuals of four small mammal species (Table 1); 16 of the captures were in sagebrush habitat. The Deer Mouse was the most abundant and widespread species (18 individuals from 7 trap lines). Dennis Flath (personal communication) captured 28 small mammals on 7 August 1979 in "saline lowland range type" in the SE part of Section 10: 26 individuals were Deer Mice and two were Sagebrush Voles. In 2000 and 2001, we captured no voles of the genus Microtus, and runways were absent in the grassland habitats we examined. Voles may have been at a low in their multi-year population cycle, or the drought may have eliminated voles from the vicinity of Wild Horse Lake at the time of our inventory. The single Meadow Vole (Microtus pennsylvanicus) we documented (in a raptor pellet), may have been carried to the Lund Easement with the Pygmy Shrew from another locality.

\section{- Birds}

We documented 43 bird species on the Lund Easement and in adjacent areas (Appendix A). Of these, 17 species were confirmed breeding, 9 were probably breeding, and 17 species exhibited no evidence of breeding, although most of the species in this last group undoubtedly breed in the area. The list of species is by no means complete, as the lack of surface water contributed to the relatively few waterbird and shorebird species we observed, as did limited field time at the study site. Extreme drought conditions may have contributed to the absence of some passerine species as well, such as Baird's Sparrow and Grasshopper Sparrow that favor at least some moderately tall $(15-40 \mathrm{~cm})$ standing grass (Madden et al, 2000). These two sparrows, one a Species of Concern and, the other on the state Species of Potential Concern list due to declining trend, should be looked for during years of normal or above average precipitation. Both species are local but widespread throughout northeastern Montana (Montana Bird Distribution Committee, 1996). 
Bird species observed in the study area represent an avifauna typical of northern prairie grasslands in North America, and included three species (Sprague’s Pipit, McCown's Longspur, Chestnut-collared Longspur) endemic to the Northern Great Plains. Seven bird species, all confirmed or probable breeders in the study area in 2000-2001, are on the state Species of Potential Concern list due to declining trends (Appendix A). Another three bird species (Ferruginous Hawk, Burrowing Owl, and Sprague’s Pipit) are state Species of Concern (Carlson, 2001).

Ferruginous Hawk: One tree nest was found in July 2000 at the abandoned residence in Section 8. Although not active at the time, recent whitewash, pellets, and tail feathers identified the nest as belonging to this species and recently active. Two different birds were observed soaring over the area. In May 2001 an active nest was found in the windbreak in Section 22 south of the Lund Easement (Figure 2). An incubating or brooding adult flushed from the nest on 27 May, but nest contents were not checked. It is likely that these two nest sites represent one nesting territory.

Figure 2. Bird nest and small mammal trap locations

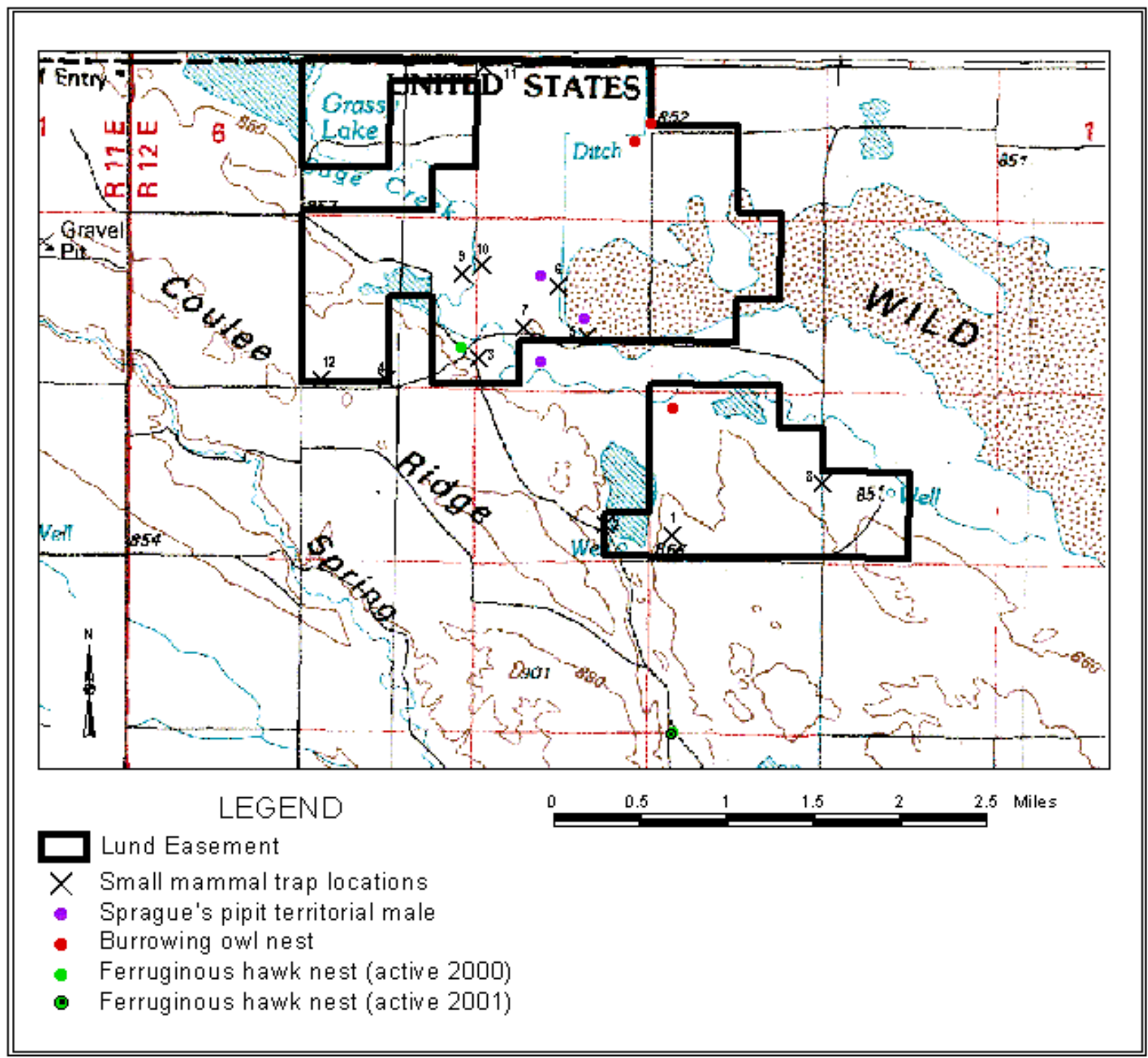


Burrowing Owl: Two nests in ground squirrel burrows were found in July 2000. One adult and one chick were observed at the nest in Section 15, two adults and nine chicks were observed at the nest in Section 4. In May 2001 a pair of adults was active in the general vicinity of the 2000 nest in Section 4. Following a brief observation period one of the adults entered a ground squirrel burrow along the NW edge of Section 3 and remained below ground. Accumulated pellets and whitewash indicated this site was an active nest, probably occupied by the pair of owls that nested in Section 4 the previous year.

Sprague's Pipit: Five territorial males were observed performing aerial song displays during 18-20 July over an extensive portion of dry lakebed in Section 9 where there was dense grass and sedge cover of moderate height (about $20 \mathrm{~cm}$ ). This area seemed even drier in May 2001 (no green vegetation), and no pipits were seen or heard during that visit.

\section{- Natural Communities}

In all, twelve terrestrial plant communities were documented in the Lund easement. The greasewood / western wheatgrass (Sarcobatus vermiculatus / Pascopyrum smithii) Shrub Herbaceous community is perhaps the most extensive in the state of Montana; it is found throughout the Wild Horse Lake basin with the greatest area on neighboring land managed by the Bureau of Land Management. Figure 3 illustrates the dominant vegetation communities on the easement.

Figure 3. Plant associations on the Lund Easements

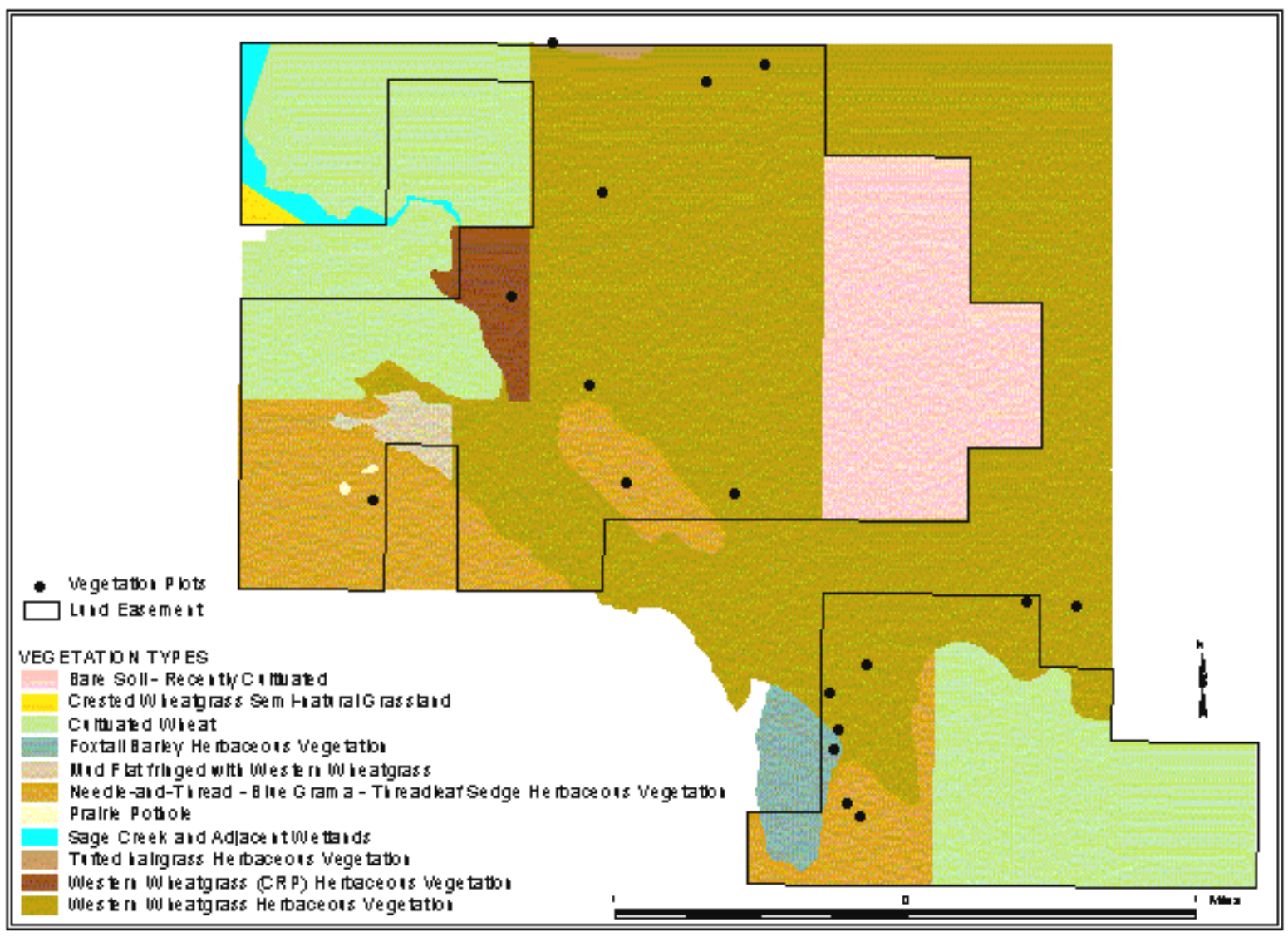

Two uncommon plant communities were recorded; the first, a silver sage / needle-and-thread grass (Artemisia cana / Hesperostipa comata) Shrub Herbaceous Vegetation was noted along the eastern edge of the ephemeral lake bottom at T37N R12E Section 15. This shrub prairie association occurs in small patches and has a very narrowly circumscribed geographic distribution in the northwestern Great Plains.

This vegetation type grows on well-drained benches and gently inclined landforms and has put this community at moderate risk of conversion to agricultural crops in farming landscapes. The other uncommon plant community is the Prairie Sandreed - Sedge Prairie Herbaceous Vegetation (Calamovilfa 


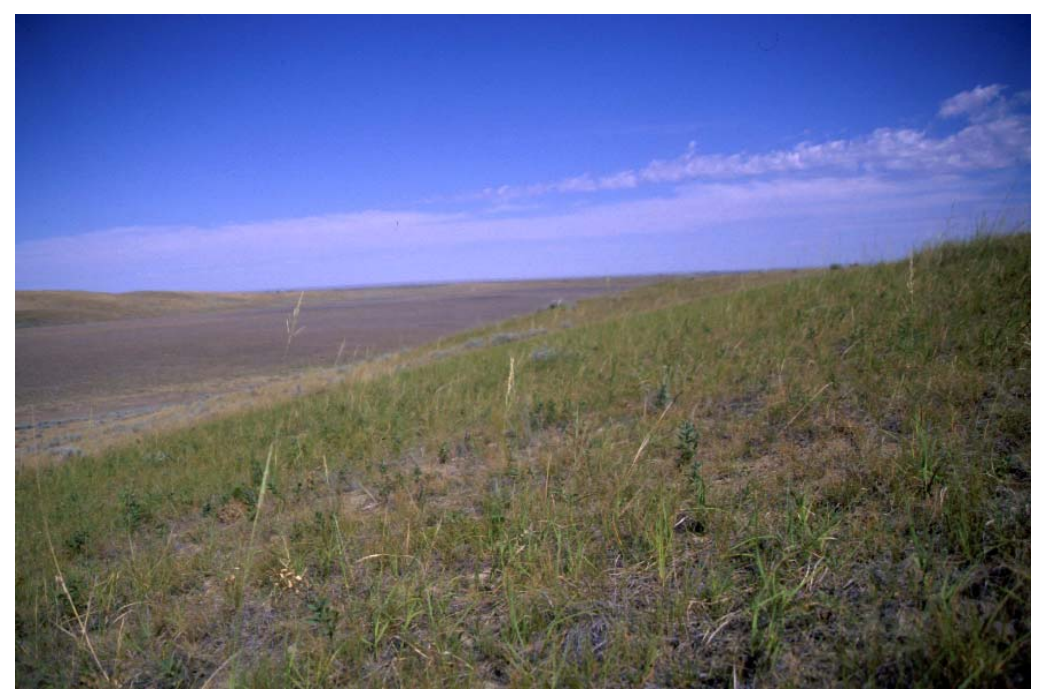

Prairie - Sandreed - Thin-leaved Sedge longifolia - Carex inops spp.

heliophilia). This community is also confined to the northwestern Great Plains of the United States and Canada. Stands typically occur on gentle slopes but can also be found on flat land or moderate to steep slopes. Soils are thin sands, sandy loams, and loamy sands, in places derived from sandstone. On the Lund easement, this type occurs as small patches on sandy ecological sites elevated above the lake basin and is codominated by thread-leaved sedge (Carex filifolia) rather than sun sedge. Table 4 lists all twelve communities and gives the state and national rank. Complete community association and alliance descriptions are found in Appendix B.

Table 4. Plant Associations documented in the Lund Easement

\begin{tabular}{|c|c|c|}
\hline Scientific Name & $\begin{array}{l}\text { State } \\
\text { Rank }\end{array}$ & $\begin{array}{l}\text { Global } \\
\text { Rank }\end{array}$ \\
\hline $\begin{array}{l}\text { Agropyron cristatum Semi-natural Herbaceous Vegetation } \\
\text { Crested Wheatgrass Semi-natural Grassland }\end{array}$ & SC & GC \\
\hline $\begin{array}{l}\text { Artemisia cana / Hesperostipa comata Shrub Herbaceous Vegetation } \\
\text { Silver Sage/ Needle-and-thread }\end{array}$ & S3 & G3 \\
\hline $\begin{array}{l}\text { Calamovilfa longifolia - Carex inops spp. heliophilia Herbaceous Vegetation } \\
\text { Prairie Sandreed - Sedge Prairie Herbaceous Vegetation }\end{array}$ & S3 & G3 \\
\hline $\begin{array}{l}\text { Carex praegracilis Herbaceous Vegetation } \\
\text { Clustered Field Sedge Herbaceous Vegetation }\end{array}$ & S? & G3G4 \\
\hline $\begin{array}{l}\text { Deschampsia cespitosa Herbaceous Vegetation } \\
\text { Tufted Hairgrass Herbaceous Vegetation }\end{array}$ & S4 & G4 \\
\hline $\begin{array}{l}\text { Eleocharis palustris Herbaceous Vegetation } \\
\text { Marsh Spikerush Herbaceous Vegetation }\end{array}$ & S5 & G5 \\
\hline $\begin{array}{l}\text { Hordeum jubatum Herbaceous Vegetation } \\
\text { Foxtail Barley Herbaceous Vegetation }\end{array}$ & S4 & G4 \\
\hline $\begin{array}{l}\text { Pascopyrum smithii Herbaceous Vegetation } \\
\text { Western Wheatgrass Herbaceous Vegetation }\end{array}$ & S4 & G3G5Q \\
\hline $\begin{array}{l}\text { Poa secunda Herbaceous Vegetation } \\
\text { Sandberg's Bluegrass Herbaceous Vegetation }\end{array}$ & S? & G4? \\
\hline $\begin{array}{l}\text { Sarcobatus vermiculatus / Pascopyrum smithii Shrub Herbaceous Vegetation } \\
\text { Black Greasewood / Western Wheatgrass - Shrub Herbaceous Vegetation }\end{array}$ & S4 & G4 \\
\hline $\begin{array}{l}\text { Sarcobatus vermiculatus Shrubland } \\
\text { Black Greasewood Shrubland }\end{array}$ & S? & G5 \\
\hline $\begin{array}{l}\text { Stipa comata - Bouteloua gracilis - Carex filifolia Herbaceous Vegetation } \\
\text { Needle-and-Thread - Blue Grama Herbaceous Vegetation }\end{array}$ & S? & G5 \\
\hline
\end{tabular}




\section{- Plants}

No plants of concern were noted during the inventory in 2000, however there are several plants tracked by the Montana Natural Heritage program that may occur on the easement. These plants are mostly annuals associated with moist areas. Surveys scheduled for 2000 and 2001 were cancelled due to severe drought in the region.

\section{OTHER VALUES}

Wetlands in northern Hill Co. have been mapped by the FWS as part of the National Wetland Inventory. Wild Horse Lake, Grassy Lake. Sage Creek and scattered potholes are mapped as Palustrine wetlands (Cowardin et al, 1979) that are temporarily or seasonally flooded. An interesting and diverse mesic wet meadow is found along the Canadian border in the western portion of the easement. This wetland

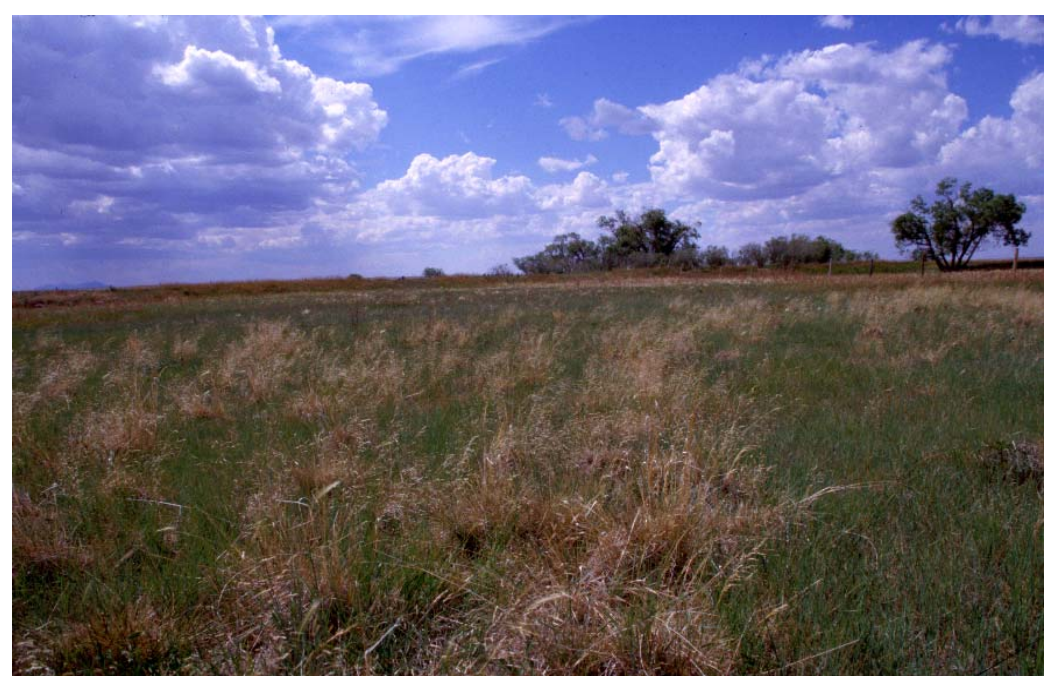
includes a tufted hairgrass herbaceous community (Deschampsia cespitosa) intermixed with western wheatgrass.

Windbreaks of Caragana (Caragana arborescens) and shade trees planted at the old homestead site provide structural diversity and nesting habitat for prairie birds.

\section{Tufted Hairgrass}

\section{LAND USE}

Land use is primarily ranching and farming. Agricultural treatments are numerous; many acres of seminatural vegetation are planted in crested wheatgrass (Agropyron cristatum) and many acres are planted as crop wheat. Portions of the old lakebed have been planted to western wheatgrass as part of the Conservation Reserve Program.

The hydrology of the lake basin has been highly modified. A series of dams, dikes, drainage and spreader ditches contain and control water during seasons of high water. Otherwise the lake basin is arid and lacks permanent water. On the easement, at least three water developments (wells) are in place, although it is not known if any of these still yield water.

\section{EXOTICS}

One noxious weed and several exotic plants, some of which are known to increase and invade natural communities are found on the easement. Unfortunately the noxious weed, Canada thistle (Cirsium arvense), is very abundant around overflow culverts and drainages ditches that are used to drain hay meadows during periods of excess water. Other notable introduced exotic species include smooth brome (Bromus inermis), reed canary grass (Phalaris arundinacea), common tansy (Tanacetum vulgare), great ragweed (Ambrosia trifida), and wild licorice (Glycyrrhiza lepidota). 


\section{UPLANDS}

Ranching and farming occur on adjacent private property. Rangelands managed by the Bureau of Land Management occur east of the property and State Trust Lands found at T37N, R12E Section 16 are used as cattle allotments.

\section{INFORMATION NEEDS}

Additional surveys are needed to complete the mammal and bird inventories. The study area falls within the range of two globally rare species on the state Species of Concern List, the G3 Swift Fox (Vulpes velox) and the G2 Mountain Plover (Charadrius montanus). Swift Fox has been reported in recent years in Hill County (Foresman, 2001a) and has reoccupied portions along the Canadian border (Jody Peters personal communication). The Mountain Plover has been reported breeding in Canada only in adjacent portions of Alberta and Saskatchewan near the international border (Wallis and Wershler, 1981). Although there are no reports from Montana in the vicinity of Wild Horse Lake, the study area deserves to be thoroughly surveyed for this bird species. These species aside, additional small mammal trapping is recommended to determine the presence or absence of Pygmy Shrew in the area. Bird surveys during years of normal or above normal precipitation are also recommended to identify the wetland species using the site when surface water is present. Currently this is largely unknown.

Baseline inventory for plants of concern should take place during a wet year. Eight annual and one perennial plant species that are wetland obligate or facultative wetland species (Reed, 1996) were identified to have potential habitat on the easement (Heidel, personal communication). These species are listed in Table 5. Species descriptions including distinguishing characteristics and habitat are available on the Montana Natural Heritage Program World Wide Web page (MTNHP, 2001).

Table 5. Plant species of concern that may potentially occur on the Lund Easement

\begin{tabular}{|l|l|l|l||}
\hline \multicolumn{1}{|c|}{ Common name followed by Scientific name } & Wetland rating & Global Rank & State Rank \\
\hline $\begin{array}{l}\text { California Waterwort } \\
\text { Elatine californica Gray }\end{array}$ & OBL & G5 & SU \\
\hline $\begin{array}{l}\text { Dense-flower Knotweed } \\
\text { Polygonum polygaloides ssp confertiflorum }\end{array}$ & FACW+, OBL & G4G5T3T4 & SU \\
\hline $\begin{array}{l}\text { Dwarf Wooly-heads } \\
\text { Psilocarphus brevissimus var brevissimus }\end{array}$ & FACW+, OBL & G5T? & S2 \\
\hline $\begin{array}{l}\text { Guadalupe Water-nymph } \\
\text { Najas guadalupensis (Spreng.) Magnus }\end{array}$ & OBL & G5 & S1 \\
\hline $\begin{array}{l}\text { Hutchinsia } \\
\text { Hutchinsia procumbens (L.) Desv }\end{array}$ & FAC & G5 & S1 \\
\hline $\begin{array}{l}\text { Poison Suckleya } \\
\text { Suckleya suckleyana (Torr.) Rydb }\end{array}$ & FAC, OBL & G5 & SU \\
\hline $\begin{array}{l}\text { Roundleaf Water-hyssop } \\
\text { Bacopa rotundifolia (Michx.) Wettst. }\end{array}$ & OBL & G5 & SH \\
\hline $\begin{array}{l}\text { Scarlet Ammannia } \\
\text { Ammannia coccinea } \text { Rottb. }\end{array}$ & FACW, OBL & G5 & SU \\
\hline $\begin{array}{l}\text { Short-seeded Water-wort } \\
\text { Elatine brachysperma Gray }\end{array}$ & OBL & G5 & S1 \\
\hline $\begin{array}{l}\text { Slender Bulrush } \\
\text { Scirpus heterochaetus Chase }\end{array}$ & FACW, OBL & G4 & S1 \\
\hline $\begin{array}{l}\text { Slender-branched Popcorn-flower } \\
\text { Plagiobothrys leptocladus (Greene) I.M. Johnston }\end{array}$ & & \\
\hline
\end{tabular}

\footnotetext{
${ }^{1}$ Obligate Wetland (OBL): Species that occur almost always (estimated probability >99\%) under natural conditions in wetlands.

Facultative Wetland (FACW): Species that usually occur in wetlands (estimated probability 67\%-99\%), but occasionally found in non-wetlands. Facultative (FAC): Species that are equally likely to occur in wetlands or non-wetlands (estimated probability 34\%-66\%).
} 


\section{MANAGEMENT NEEDS}

Maintaining diversity of native prairie cover and structure through appropriate rotational grazing techniques and prescribed fire on upland areas will help assure the continued presence of a relatively complete grassland bird fauna whose nesting habitat and vegetation-structure requirements vary among species. Studies to determine the effects of landscape patch size on breeding success of these species would also be useful. It would also be useful to develop models predicting the impact of water impoundment on species that currently use the dry lakebed for nesting.

A strategic weed management plan is needed to treat Canada thistle before this noxious weed (Rice, 2001) invades less disturbed natural communities on the easement. Canada thistle is an aggressive, creeping perennial weed that invades cultivated fields, natural hay meadows and prairies and reduces forage consumption. An integrated long-term control plan designed to stress the plant and force it to use stored root nutrients is suggested. An integrated approach utilizes a combination of cultural, chemical, mechanical and biological methods. 


\section{REFERENCES}

American Ornithologists' Union. 1998. Check-list of North American Birds. $7^{\text {th }}$ edition. American Ornithologists' Union, Washington, D.C. 829 pp.

Association for Biodiversity Information (ABI). 2001. International classification of ecological communities: terrestrial vegetation. Natural Heritage Central Databases. The Association for Biodiversity Information, Arlington, VA.

Bibby, C. J., N. D. Burgess, D. A. Hill, and S. H. Mustoe. 2000. Bird census techniques Second edition. Academic Press, London, UK. 302 pp.

Booth, W. E. 1950. Flora of Montana, part 1, conifers and monocots. The Research Foundation at Montana State College, Bozeman, MT. 232 pp.

Booth, W. E., and J. C. Wright. 1966. Flora of Montana, part 2, dicotyledons. Department of Botany and Microbiology, Montana State University, Bozeman, MT. 305 pp.

Carlson, J., 2001. Coordinator, Montana Animal Species of Concern Committee. Montana Animal Species of Concern. Montana Natural Heritage Program and Montana Fish, Wildlife and Parks, Helena. Montana. 12pp.

Cowardin, L. M., V. Carter, F. C. Golet, and E. T. LaRoe. 1979. Classification of wetlands and deepwater habitats of the United States. U.S. Department of Interior, Fish and Wildlife Service, Biological Services Program, FWS/OBS-79/31, Washington D.C.

Dorn, R. D. 1984. Vascular Plants of Montana. Mountain West Publishing, Cheyenne, WY. 276 pp.

FGDC (Federal Geographic Data Committee). 1997. FGDC Vegetation Classification and Information Standards. FGDC Secretariat, U.S. Geological Survey, Reston, Virginia, USA. http://www.nbs.gov/fgdc.veg.

Fish and Wildlife Service. 2001. Montana Partners for Fish and Wildlife, Milk River Basin Focus Area. http://mountain-prairie.fws.gov/pfw/montana/mt3g.htm. Data last accessed on September 20, 2001.

Foresman, K. R. 2001a. The wild mammals of Montana. Special Publication No. 12. American Society of Mammalogists, Lawrence, Kansas. 278 pp.

Foresman, K. R. 2001b. Key to the mammals of Montana. University of Montana Bookstore, Missoula, Montana. 92 pp.

Heidel, B. 2001. Plant Species of Concern. Montana Natural Heritage Program, Helena Montana. 38 pp.

Hendricks, P. 2001. A significant new record of Pygmy Shrew, Sorex hoyi, on the Montana-Alberta border. Canadian Field-Naturalist 115: in press.

Hitchcock and Cronquist. (1973). Flora of the Pacific Northwest. University of Washington Press, Seattle, WA. 730 pp. 
Kartesz, J.T. 1999. A Synonymized Checklist and Atlas with Biological Attributes for the Vascular Flora of the United States, Canada, and Greenland. First Edition. In: Kartesz, J.T. and C.A. Meacham. Synthesis of the North America Flora, Version 1.0 North Carolina Botanical Garden, Chapel Hill, NV, August.

Madden, E. M., R. K. Murphy, A. J. Hansen, and L. Murray. 2000. Models for guiding management of prairie bird habitat in northwestern North Dakota. American Midland Naturalist 144:377-392.

Montana Bird Distribution Committee. 1996. Skaar’s Montana bird distribution, fifth edition. Special Publication No. 3. Montana Natural Heritage Program, Helena, Montana. 130 pp.

Montana Natural Heritage Program. 2001. Plant Species Field Guide, The Montana Natural Heritage Program. http://nhp.nris.state.mt.us/.

Nesser, J. A., G. L. Ford, C. L. Maynard, and D. S. Page-Dumroese. 1997. Ecological units of the Northern Region: subsections. U.S. Department of Agriculture, Forest Service, Intermountain Research Station, General Technical Report INT-GTR-369. Ogden, UT.

Reed, Jr., Porter B. 1996. National List of Vascular Plant Species That Occur in Wetlands: 1996 National Summary (1996 National List). U.S. Fish \& Wildlife Service. Biol. Rep. 88 (24). 244 pp.

Rice, P.M. 2001. INVADERS Database System (http://invader.dbs.umt.edu). Division of Biological Sciences, University of Montana, Missoula, MT 59812-4824.

The Great Plains Flora Committee. 1977. Atlas of the Flora of the Great Plains. Iowa University Press, Ames. 600 pp.

The Great Plains Flora Committee. 1986. Flora of the Great Plains. University Press of Kansas Lawrence. 1392 pp.

The Nature Conservancy. 1999. Ecoregional Planning in the Northern Great Plains Steppe, NGPS Ecoregional Planning Team. 76 pp. plus maps.

Tu, M., Hurd, C., \& J.M. Randall, 2001. Weed Control Methods Handbook, The Nature Conservancy, http://tncweeds.ucdavis.edu. Version: April 2001.

Veseth, R., and J. C. Montagne. 1980. Geologic parent materials of Montana soils. Montana Agricultural Experiment Station, Montana State University, Bozeman, and USDA-Soil Conservation Service, Bozeman, Montana. Bulletin 721.

Wallis, C. A., and C. R. Wershler. 1981. Status and breeding of Mountain Plovers (Charadrius montanus) in Canada. Canadian Field-Naturalist 95:133-136. 


\section{Appendix A.}

Birds observed in the Wild Horse Lake study area, Hill County, Montana. Breeding status codes are as follows: O (no evidence of breeding), b (strong evidence of breeding; territorial behavior, pairs, juveniles), B (breeding confirmed; nests found, dependent young). Species common names in bold are Montana Species of Concern; species common names in italics are on the Species of Potential Concern List due to declining trends (Carlson, 2001). Names and sequence follow the A.O.U. Checklist, $7^{\text {th }}$ edition (1998).

Canada Goose (Branta canadensis)

Mallard (Anas platyrhynchus)

Northern Harrier (Circus cyaneus)

Swainson's Hawk (Buteo swainsoni)

Red-tailed Hawk (Buteo jamaicensis)

Ferruginous Hawk (Buteo regalis)

Golden Eagle (Aquila chrysaetos)

Prairie Falcon (Falco mexicanus)

Ring-necked Pheasant (Phasianus colchicus)

Sharp-tailed Grouse (Tympanuchus phasianellus)

Killdeer (Charadrius vociferus)

Willet (Catoptrophorus semipalmatus)

Upland Sandpiper (Bartramia longicauda)

Long-billed Curlew (Numenius americanus)

Marbled Godwit (Limosa fedoa)

Wilson's Phalarope (Phalaropus tricolor)

Mourning Dove (Zenaida macroura)

Great Horned Owl (Bubo virginianus)

Burrowing Owl (Athene cunicularia)

Short-eared Owl (Asio flammeus)

Common Nighthawk (Chordeiles minor)

Say's Phoebe (Sayornis saya)

Western Kingbird (Tyrannus verticalis)

Eastern Kingbird (Tyrannus tyrannus)

Loggerhead Shrike (Lanius ludovicianus)

Horned Lark (Eremophila alpestris)

Barn Swallow (Hirundo rustica)

Brown Thrasher (Toxostoma rufum)

European Starling (Sturnus vulgaris)

Sprague's Pipit (Anthus spragueii)

Clay-colored Sparrow (Spizella pallida)

Brewer's Sparrow (Spizella breweri)

Vesper Sparrow (Pooecetes gramineus)

Lark Sparrow (Chondestes grammacus)

Lark Bunting (Calamospiza melanocorys)

Savannah Sparrow (Passerculus sandwichensis)

McCown's Longspur (Calcarius mccownii)

Chestnut-collared Longspur (Calcarius ornatus)

Red-winged Blackbird (Agelaius phoeniceus)

Western Meadowlark (Sturnella neglecta)

Brewer's Blackbird (Euphagus cyanocephalus)

Common Grackle (Quiscalus quiscula)

Brown-headed Cowbird (Molothrus ater)
O (flyover; 2001)

O (2001)

O (2000, 2001)

B (2 nests; 2000, 2001)

$\mathrm{O}(2000,2001)$

B (2 nests; 2000, 2001)

O (2001)

$\mathrm{O}(2000)$

O (2000)

b (2 immatures; 2000)

B (downy young; 2001)

O (2001)

O (2000, 2001)

b (pair; 2001)

O (2001)

O (2001)

B (10 nests in wind break; 2001)

B (adult + downy chick; 2001)

B (3 nests, incl. broods; 2000, 2001)

$\mathrm{O}(2000)$

O (2000, 2001)

O (2000, 2001)

O (2000, 2001)

B (nest with eggs; 2000)

B (1 brood; 2000: 2 nests; 2001)

b (fledged young; 2000, 2001)

B (nests in buildings; 2000, 2001)

O (in wind break; 2001)

B (3 nests in wind break; 2001)

b (5 territorial males; 2000)

b (singing males; 2001)

B (dependent fledglings; 2000)

B (nest with eggs; 2001)

b (singing males; 2001)

B (2 nests with eggs or young; 2000)

B (nest with young: 2000)

b (singing males; 2000, 2001)

B (nest with eggs; 2001)

b (singing males; 2001)

b (singing males; 2000, 2001)

B (10 nests in wind break; 2001)

O (2001)

B (juv. with Lark Bunting; 2000) 


\title{
INTERNATIONAL CLASSIFICATION OF ECOLOGICAL COMMUNITIES:
}

\section{TERRESTRIAL VEGETATION OF THE UNITED STATES}

Wild Horse Lake: Lund Easement

\author{
Report from \\ Biological Conservation Datasystem \\ September, 2001 \\ by \\ Association for Biodiversity Information \\ 1101 Wilson Blvd., $15^{\text {th }}$ floor \\ Arlington, VA 22209
}

This subset of the International Classification of Ecological Communities (ICEC) covers vegetation alliances and associations attributed to the Hill County, Montana. This community classification has been developed in consultation with many individuals and agencies and incorporates information from a variety of publications and other classifications.

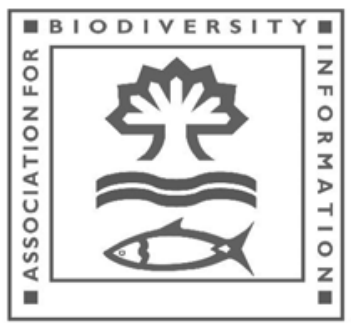




\section{Copyright (C) 2001 The Association for Biodiversity Information, 1101 Wilson Blvd, $15^{\text {th }}$ floor \\ Arlington, VA 22209, U.S.A. All Rights Reserved.}

The following citation should be used in any published materials, which reference these data:

The Association for Biodiversity Information. 2001. International Classification of Ecological Communities:

Terrestrial Vegetation. Natural Heritage Central Databases. The Association for Biodiversity Information, Arlington, VA.

Restrictions on Use: Permission to use, copy and distribute these data is hereby granted under the following conditions:

1. The above copyright notice must appear in all documents and reports;

2. Any use must be for informational purposes only and in no instance for commercial purposes;

3. Some data may be altered in format for analytical purposes, however the data should be referenced using the citation above.

Any rights not expressly granted herein are reserved by The Association for Biodiversity Information. Except as expressly provided above, nothing contained herein shall be construed as conferring any license or right under any Association for Biodiversity Information copyright.

Information Warranty Disclaimer: All data are provided as is without warranty as to the currentness, completeness, or accuracy of any specific data. The Association for Biodiversity Information hereby disclaims all warranties and conditions with regard to these data, including but not limited to all implied warranties and conditions of merchantability, fitness for a particular purpose, and non-infringement. In no event shall the Association for Biodiversity Information be liable for any special, indirect, incidental, consequential damages, or for damages of any kind arising out of or in connection with the use of these data. Because the data in the Natural Heritage Central Databases are continually being updated, it is advisable to refresh data at least once a year after its receipt. The data provided are for planning, assessment, and informational purposes. Site specific projects or activities should be reviewed for potential environmental impacts with appropriate regulatory agencies. 


\section{TABLE OF CONTENTS}

III.A.4.N.c. Temporarily flooded microphyllous shrubland ..................................................................... 2

III.A.4.N.c.2. ARTEMISIA CANA TEMPORARILY FLOODED SHRUBLAND ALLIANCE ...................2

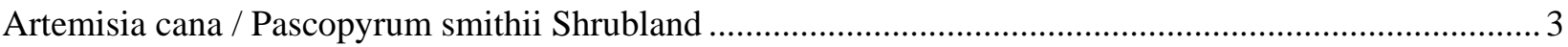

III.B.3.N.b. Intermittently flooded extremely xeromorphic deciduous subdesert shrubland ............................ 5

III.B.3.N.b.3. SARCOBATUS VERMICULATUS INTERMITTENTLY FLOODED SHRUBLAND

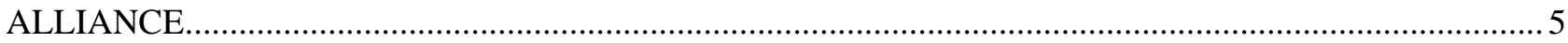

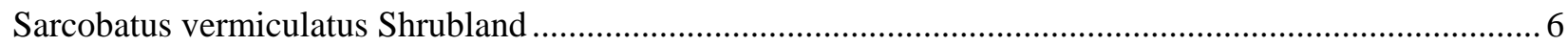

V.A.5.N.c. Medium-tall sod temperate or subpolar grassland..................................................................... 8

V.A.5.N.c.29. HESPEROSTIPA COMATA - BOUTELOUA GRACILIS HERBACEOUS ALLIANCE.....8

Hesperostipa comata - Bouteloua gracilis - Carex filifolia Herbaceous Vegetation..................................... 9

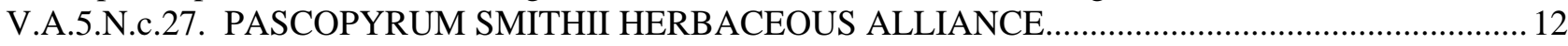

Pascopyrum smithii Herbaceous Vegetation ........................................................................................... 13

V.A.5.N.j. Temporarily flooded temperate or subpolar grassland.............................................................. 15

V.A.5.N.j.22. HORDEUM JUBATUM TEMPORARILY FLOODED HERBACEOUS ALLIANCE ......... 15

Hordeum jubatum Herbaceous Vegetation ......................................................................................... 16

V.A.5.N.k. Seasonally flooded temperate or subpolar grassland............................................................... 17

V.A.5.N.k.58. CAREX PRAEGRACILIS SEASONALLY FLOODED HERBACEOUS ALLIANCE.......17

Carex praegracilis Herbaceous Vegetation ......................................................................................... 18

V.A.5.N.k.47. DESCHAMPSIA CAESPITOSA SEASONALLY FLOODED HERBACEOUS ALLIANCE

Deschampsia caespitosa Herbaceous Vegetation.....................................................................................2 20

V.A.5.N.k.61. ELEOCHARIS PALUSTRIS SEASONALLY FLOODED HERBACEOUS ALLIANCE... 21

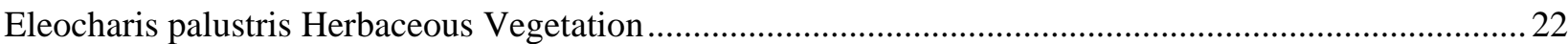

V.A.5.N.k.49. POA SECUNDA SEASONALLY FLOODED HERBACEOUS ALLIANCE ......................24

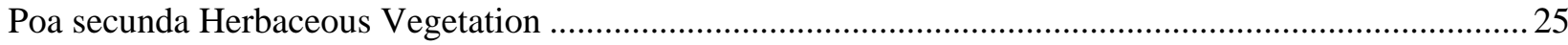

V.A.7.N.e. Medium-tall temperate or subpolar grassland with a sparse needle-leaved or microphyllous

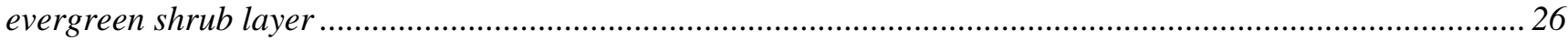

V.A.7.N.e.11. ARTEMISIA CANA SHRUB HERBACEOUS ALLIANCE ..........................................26

Artemisia cana / Hesperostipa comata Shrub Herbaceous Vegetation ....................................................... 27

V.A.7.N.n. Intermittently flooded temperate or subpolar grassland with a sparse xeromorphic (evergreen

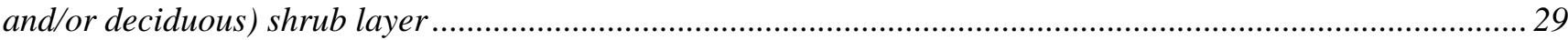

V.A.7.N.n.1. SARCOBATUS VERMICULATUS INTERMITTENTLY FLOODED SHRUB

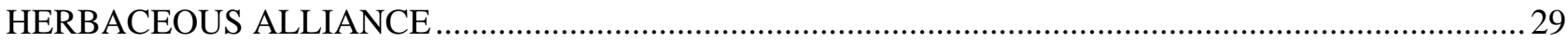

Sarcobatus vermiculatus / Pascopyrum smithii - (Elymus lanceolatus) Shrub Herbaceous Vegetation...... 30 


\title{
III.A.4.N.c. Temporarily flooded microphyllous shrubland
}

\author{
III.A.4.N.c.2. ARTEMISIA CANA TEMPORARILY FLOODED SHRUBLAND ALLIANCE \\ Silver Sagebrush Temporarily Flooded Shrubland Alliance
}

\begin{abstract}
Alliance Concept
Summary: This alliance is found in the northwestern Great Plains and interior northwestern United States. This description is based largely on the type within this alliance that occurs in North and South Dakota. Stands of this alliance are found predominantly on floodplains or flat terraces near watercourses. The soils are derived from alluvial deposits and are often not well-developed. They are almost always loams, either sandy loams, silt loams, or clay loams. Flooding may occur periodically. Stands within this alliance are dominated by shrubs and graminoids approximately $1 \mathrm{~m}$ tall. Total vegetation cover is moderate. Graminoids make up the majority of the canopy, but the shrub layer is taller and thus more noticeable. Artemisia cana is the dominant, and often only, shrub in this stratum. Symphoricarpos occidentalis is present to common in some stands. There are also shorter shrubs such as Artemisia frigida, Krascheninnikovia lanata, Rosa woodsii, and Gutierrezia sarothrae. These rarely exceed $0.5 \mathrm{~m}$. The most abundant midgrass in the Midwest is Pascopyrum smithii, with smaller amounts of Nassella viridula, Hesperostipa comata (= Stipa comata), Koeleria macrantha, and Poa pratensis. The shortgrass Bouteloua gracilis is usually present and may be very common. Forbs are present but do not contribute much of the vegetation cover in this alliance. Among the forbs that are typically found in this alliance are Achillea millefolium, Gaura coccinea, Sphaeralcea coccinea, Lactuca tatarica var. pulchella, and Taraxacum officinale.
\end{abstract}

Environment: These shrublands occur throughout the northern half of the Intermountain West, usually at middle elevations (1000-2500 (3000) $\mathrm{m}$ ), and into the northern Great Plains at 500-1000 $\mathrm{m}$ in elevation. Across the range of the alliance there is great variation in precipitation, with less than $25 \mathrm{~cm}$ in semi-arid basins of the western Great Basin. In the northwestern Great Plains this alliance is found on flat alluvial deposits on floodplains, terraces or benches, or alluvial fans. The soils are moderately deep to deep and either silt loam, clay loam, or sandy loam. Flooding may occur periodically and this tends to retard soil development. In the northern Great Basin (Oregon) stands are found in playas on sites that are flooded for several months during the winter and early spring but which rapidly dry up as the weather warms. Soils are saline. In more saline soils at slightly lower elevations on the playa, Artemisia cana / Eleocharis palustris and Eleocharis palustris communities occur. In general, these communities show an affinity for mild topography, fine to somewhat coarse alluvial soils, and some source of subsurface moisture.

Vegetation: This vegetation is reported from the northwestern Great Plains and interior northwestern United States. In all stands, Artemisia cana is the dominant, and often, only shrub, but Ericameria nauseosa (= Chrysothamnus nauseosus) is usually present. Other shorter shrubs may occur or even be common, including Symphoricarpos occidentalis, Artemisia frigida, Rosa woodsii, and Gutierrezia sarothrae. There is usually a well-developed graminoid layer, with cover often exceeding the cover of the shrub layer. The dominant species include Pascopyrum smithii, or Poa secunda. Other important grasses include Distichlis spicata, Elymus elymoides, Nassella viridula, Hesperostipa comata (= Stipa comata), Bouteloua gracilis, Koeleria macrantha, or Eleocharis palustris. Forbs are present but do not contribute much of the vegetation cover. Among the forbs that are typically found in Great Plains stands are Achillea millefolium, Gaura coccinea, Sphaeralcea coccinea, and Lactuca tatarica var. pulchella. In Oregon stands, forbs include Lupinus argenteus, Trifolium gymnocarpon, Astragalus lentiginosus, Polyctenium fremontii, and Camissonia tanacetifolia.

Dynamics: These communities occur in mild alluvial terrain which is often grazed by domestic livestock and is strongly preferred during the growing season (Padgett et al. 1988). Prolonged livestock use of these habitats can cause decreases in the abundance of native bunch grasses and increases in cover of shrubs and non-native species, such as Poa pratensis.

Artemisia cana resprouts vigorously following spring fire, and this method may serve to increase shrub coverage of stands. Conversely, fire in the fall may decrease shrub abundance (Hansen et al. 1995). Sarr (1995) noted that Artemisia cana was associated with higher floodplain terraces of alluvial meadows where the late summer water table averaged 0.8-1.5 $\mathrm{m}$ below the surface. Gully erosion of meadows led to an invasion of this type to formerly wet meadows. Comparisons of grazed and protected floodplain sites showed a tendency for Artemisia cana to occur more commonly in grazed than ungrazed habitats of the similar groundwater hydrology. 


\section{ALLIANCE Distribution}

Range: This alliance is found in the western United States in Oregon, possibly Nevada, and Montana. One community extends into the northwestern Great Plains in the western portions of Nebraska, and North and South Dakota. The alliance probably also occurs in Alberta and Saskatchewan, Canada.

Nations: CA? US

States/Provinces: CA? MT ND NE NV? OR SD

USFS Ecoregions: 251Aa:CCC, 331D:CC, 331F:CC, 331G:CC, 342B:CC, 342C:CC, M331A:CC, M332B:C?, M332D:CC, M332E:CC, M332G:CC

Authors: D. SARR, WCS Identifier: A.843

Alliance Sources

References: Chappell et al. 1997, Faber-Langendoen et al. 1996, Hansen et al. 1984, Hansen et al. 1991, Hansen et al. 1995, Hanson and Whitman 1938, Johnston 1987, Manning and Padgett 1991, Manning and Padgett 1995, Oregon Natural Heritage Program (ORNHP) n.d., Sarr 1995, U.S. Forest Service (USFS) 1992

ARTEMISIA CANA / PASCOPYRUM SMITHII SHRUBLAND

Silver Sagebrush / Western Wheatgrass Shrubland

Silver Sagebrush / Western Wheatgrass Shrubland

\section{ELEMENT CONCEPT}

Summary: This silver or coaltown sagebrush shrubland is found in the northwestern Great Plains and Rocky Mountains of the western United States. Stands occur on flat alluvial deposits on floodplains, terraces or benches, or alluvial fans. The soils are moderately deep to deep and either silt loam, clay loam, or sandy loam. Flooding may occur periodically and this tends to retard soil development. This community is dominated by a combination of shrubs and graminoids. The total vegetation cover is moderate. The tallest and most conspicuous stratum in this community is a shrub layer that is usually $0.6-1.2 \mathrm{~m}$. Artemisia cana is the dominant in this layer and may be accompanied by Symphoricarpos occidentalis. Also present are shorter shrubs such as Artemisia frigida, Krascheninnikovia lanata, Rosa woodsii, and Gutierrezia sarothrae. The most abundant graminoid is Pascopyrum smithii. This species is typically 0.5-1.0 m tall. It is often accompanied by Nassella viridula and sometimes Koeleria macrantha, Poa pratensis, and Hesperostipa comata (= Stipa comata). Bouteloua gracilis is the most abundant short graminoid. Typical forb constituents of this community are Achillea millefolium, Gaura coccinea, Sphaeralcea coccinea, and Lactuca tatarica var. pulchella.

Environment: This community occurs on flat alluvial deposits on floodplains, terraces or benches, or alluvial fans. The soils are moderately deep to deep (USFS 1992) and either silt loam, clay loam, or sandy loam (Johnston 1987, Hansen and Hoffman 1988). The soils may have moderate salt content (Hanson and Whitman 1938). Flooding occurs periodically and this tends to retard soil profile development (Hirsch 1985).

Vegetation: This community is dominated by a combination of shrubs and graminoids. The total vegetation cover is typically moderate, but depends on frequency of flooding. The tallest and most conspicuous stratum is a shrub layer that is usually 0.6-1.2 m (Hansen and Hoffman 1988). In 14 stands in western North Dakota shrubs averaged 28\% canopy cover, graminoids 59\%, and forbs $2 \%$ (USFS 1992). Stands in Nebraska often have less than $15 \%$ cover. The variation in soils within and between stands of this community results in variable species composition. Artemisia cana is the dominant shrub. Symphoricarpos occidentalis is frequently present. There are also shorter shrubs such as Artemisia frigida, Krascheninnikovia lanata, Rosa woodsii, and Gutierrezia sarothrae. The most abundant graminoid is Pascopyrum smithii. This species is typically 0.5-1.0 m tall. It is often accompanied by Nassella viridula and sometimes Koeleria macrantha, Poa pratensis, and Hesperostipa comata (= Stipa comata). Bouteloua gracilis is the most abundant short graminoid. Typical forb constituents of this community are Achillea millefolium, Gaura coccinea, Sphaeralcea coccinea, and Lactuca tatarica var. pulchella.

Dynamics: Periodic flooding occurs in many stands of this community.

\section{Similar Associations:}

Synonymy:

- Artemisa cana / Agropyron smithii Habitat Type (Hansen et al. 1984) =

- Artemisia cana Habitat Type (Hirsch 1985) =

- Sagebrush Type (Hanson and Whitman 1938) = 
- Artemisa cana / Elytrigia smithii Plant Association (Johnston 1987) B

- Artemisa cana - Symphoricarpos occidentalis / Elytrigia smithii Plant Association (Johnston 1987) =

- Artemisa cana / Agropyron smithii Habitat Type (U.S. Forest Service (USFS) 1992) =

GRank \& Reasons: G4 (96-02-01).

High-ranked species:

Comments: See Steinauer and Rolfsmeier (2000) for a description of the stands in Nebraska.

\section{ELEMENT DISTRIBUTION}

Range: This silver or coaltown sagebrush shrubland is found in the northwestern Great Plains and Rocky Mountains of the western United States, ranging from Montana and North Dakota, south to Nebraska.

Nations: US

States/Provinces: MT:S4, ND:S2S3?, NE:S?, SD:SU

USFS Ecoregions: 251Aa:CCC, 331D:CC, 331F:CC, 331G:CC, M331A:CC, M332B:C?, M332D:CC, M332E:CC, M334A:CC

ELEMENT SOURCES

Authors: Drake, J. F., WCS Confidence: 1 Identifier: CEGL001072

References: Hansen and Hoffman 1988, Hansen et al. 1984, Hansen et al. 1991, Hansen et al. 1995, Hanson and Whitman 1938, Hirsch 1985, Johnston 1987, Nelson 1961, Steinauer and Rolfsmeier 2000, U.S. Forest Service (USFS) 1992 


\title{
III.B.3.N.b. Intermittently flooded extremely xeromorphic deciduous subdesert shrubland
}

\author{
III.B.3.N.b.3. SARCOBATUS VERMICULATUS INTERMITTENTLY FLOODED \\ SHRUBLAND ALLIANCE \\ Black Greasewood Intermittently Flooded Shrubland Alliance
}

\begin{abstract}
Alliance Concept
Summary: This widespread shrubland alliance occurs on lowland sites in plains, mountain valleys and intermountain basins throughout the arid and semi-arid western United States. Sites are generally flat, poorly drained and intermittently flooded with a shallow or perched water table often within $1 \mathrm{~m}$ depth such as alkali flats around playas and floodplains along stream channels. Substrates are generally shallow, calcareous, fine-textured soils derived from alluvium. Soils are alkaline and typically moderately saline. Shrublands included in this alliance are dominated or codominated by Sarcobatus vermiculatus. Other shrubby codominants include Picrothamnus desertorum (= Artemisia spinescens), Artemisia tridentata, Atriplex confertifolia, Atriplex gardneri, Chrysothamnus spp., or Grayia spinosa. In more saline environments, Nitrophila occidentalis and Suaeda moquinii may be present. If present, the sparse to moderate herbaceous layer is dominated by perennial grasses, such as Distichlis spicata and Pascopyrum smithii, or the perennial bunch grasses Elymus elymoides, Hordeum jubatum, Leymus cinereus, and Achnatherum hymenoides (= Oryzopsis hymenoides) will dominate. Perennial forbs are typically sparse and often include Grindelia squarrosa, Iva axillaris, and Sphaeralcea coccinea. Annual grasses, especially the exotic Bromus spp., may be present to abundant. Forbs are common on disturbed sites. Weedy annual forbs may include the exotics Descurainia spp., Helianthus annuus, Halogeton glomeratus, Lactuca serriola, and Lepidium perfoliatum. Diagnostic of this alliance is the Sarcobatus vermiculatus-dominated shrub layer in a shrubland that has a relatively shallow water table and may be flooded intermittently during the growing season.
\end{abstract}

Environment: Shrublands included in this alliance occur on lowland sites in plains, mountain valleys and intermountain basins throughout the arid and semi-arid western United States. Elevations range from 100-2400 m. Summers are hot. Winters are generally cold, but are mild in subtropical regions. Precipitation varies with geography but is generally low and infrequent. Sites are generally flat, poorly drained and intermittently flooded with a shallow or perched water table often within $1 \mathrm{~m}$ depth (West 1983b). Substrates are generally shallow, calcareous, fine-textured soils (clays to silt-loams), derived from alluvium. Soils are alkaline and typically moderately saline (West 1983b).

Adjacent upland vegetation depends on geography. In the Great Plains, it is likely shortgrass or midgrass prairie. In the Great Basin and central Wyoming, upland vegetation is typically Artemisia spp.- or Grayia spinosa-dominated shrublands. In the Mojave and other warm desert sites, Larrea tridentata, Grayia spinosa, or Atriplex spp. dominate the upland sites. In the California Central Valley adjacent upland vegetation is dominated by Atriplex spp. with annual grasses. Lowland vegetation is typically sparser stands of Sarcobatus vermiculatus or stands of species more tolerant of saline soils or poor soil aeration such as Distichlis spicata, Allenrolfea occidentalis or Suaeda moquinii (Franklin and Dyrness 1973, Young et al. 1986).

Vegetation: This widespread alliance includes shrublands from alkali flats around playas and floodplains along stream channels that dissect much of the arid and semi-arid western U.S. Stands have a moderately dense to dense woody layer (20$60 \%$ cover) dominated or codominated by the deciduous, facultative halophytic shrub Sarcobatus vermiculatus. Other shrubby codominants include Picrothamnus desertorum (= Artemisia spinescens), Artemisia tridentata, Atriplex confertifolia, Atriplex gardneri, Chrysothamnus spp. or Grayia spinosa. In more saline environments, Nitrophila occidentalis and Suaeda moquinii may be present. Herbaceous layers range from absent to a moderately dense canopy of medium-tall to short bunch grasses or sod grasses (0-25\% cover). If the herbaceous layer is present, perennial grasses such as the strongly rhizomatous Distichlis spicata and Pascopyrum smithii, or the perennial bunch grasses Elymus elymoides, Hordeum jubatum, Leymus cinereus, and Achnatherum hymenoides (= Oryzopsis hymenoides) will dominate. Perennial forbs are typically sparse and often include Grindelia squarrosa, Iva axillaris, and Sphaeralcea coccinea. Annual grasses, especially the exotic Bromus japonicus, Bromus rubens, and Bromus tectorum, may be present to abundant. Forbs are common on disturbed weedy sites. Weedy annual forbs may include the exotics Descurainia spp., Helianthus annuus, Halogeton glomeratus, Lactuca serriola, and Lepidium perfoliatum.

Dynamics: Sarcobatus vermiculatus, like many facultative halophytes, is tolerant of alkaline and saline soil conditions that allow the species to occur in sites with less interspecific competition (Ungar et al. 1969, Branson et al. 1976). The shrub also occurs on extremely arid non-saline sites. Sarcobatus vermiculatus is often found on sites with high water tables that are intermittently flooded. Hansen et al. (1995) reported that it can tolerate saturated soil conditions for up to 40 days. Sarcobatus 
vermiculatus-dominated vegetation can occur as a narrow band along a channel, or in a mosaic of communities where composition and density of the shrub and understory species vary with depth to water table, salinity and alkalinity, soil texture, and past land use or disturbance. Hanson (1929) described stands in south-central Colorado and found that pure stands of Sarcobatus vermiculatus and Distichlis spicata are more common on strongly saline/alkaline sites with finetextured soil and shallow water tables, whereas stands with mixed shrubs such as Chrysothamnus or Artemisia are more common on drier, coarser textured, low-alkaline sites. Sporobolus airoides is found on dry, strongly alkaline sites, and Pascopyrum smithii is most common on less alkaline, moist, sites in low lying areas.

Sarcobatus vermiculatus is not ordinarily browsed, but Daubenmire (1970) found that under heavy stocking rates, the shrubs will develop a compact canopy. Hansen et al. (1995) also reported browsing damage with heavy spring and summer grazing, but noted that Sarcobatus vermiculatus is moderately poisonous to livestock especially in the fall, and supplemental feed is recommended to avoid livestock loss. Hanson (1929) states that Sarcobatus vermiculatus can form an important part of winter forage for sheep. Fire will topkill Sarcobatus vermiculatus, but the shrub will promptly resprout from the root crown (Daubenmire 1970).

NRCS range sites for the eastern plains of Colorado do not describe this alliance on good condition sites. Several range sites (Salt flat \#33, Saline overflow \#37) list Sarcobatus vermiculatus as present in low abundance in good condition stands but describe it as increasing with overgrazing. The NRCS range sites also describe Bouteloua gracilis increasing with overgrazing. Stands dominated by Sarcobatus vermiculatus with an understory dominated by Bouteloua gracilis been observed in eastern Colorado (S. Kettler pers. obs.).

\section{Alliance Distribution}

Range: Shrublands included in this alliance occur in floodplains along water courses and around pluvial lakes and playas throughout much of the arid and semi-arid western U.S.

Nations: US

States/Provinces: CA CO ID MT NM NV OR TX? UT WA WY

USFS Ecoregions: 313B:CC, 331D:CC, 331G:CC, 341A:CC, 341E:CC, 342A:CC, 342B:CC, 342C:CC, 342F:CC, 342G:CC, 342I:CC, M261G:CC, M313A:CC, M331B:??, M332E:CC, M332G:CC, M341:C

Authors: K. SCHULZ, JT, WCS Identifier: A.1046

\section{Alliance Sources}

References: Barbour and Major 1977, Blackburn et al. 1969, Blackburn et al. 1969c, Blackburn et al. 1969d, Blackburn et al. 1971, Branson and Owen 1970, Branson et al. 1976, Brotherson et al. 1986, Brown 1982, Bundy et al. 1996, Chappell et al. 1997, Copeland 1979, Copeland and Greene 1982, Dastrup 1963, Daubenmire 1970, DeVelice and Lesica 1993, DeVelice et al. 1991, DeVelice et al. 1995, Dick-Peddie 1993, Fenemore 1970, Francis 1986, Franklin and Dyrness 1973, Graham 1937, Hamner 1964, Hansen et al. 1995, Hanson 1929, Holland 1986, Johnston 1987, Lesica and DeVelice 1992, Medicine Bow Mine Application n.d., Mueggler and Stewart 1980, Sawyer and Keeler-Wolf 1995, Sweetwater Uranium Project 1978, Terwilliger and Smith 1978, Tweit and Houston 1980, Ungar et al. 1969, West 1983b, Young et al. 1986

\section{SARCOBATUS VERMICULATUS SHRUBLAND}

Black Greasewood Shrubland

Summary: Community description in preparation

\section{ELEMENT CONCEPT}

Environment:

Vegetation:

Dynamics:

Similar Associations:

Synonymy:

GRank \& Reasons: G5 (94-02-23).

High-ranked species:

Comments: Stands included in this association are often affected by livestock grazing.

\section{Range:}

ELEMENT DISTRIBUTION 
Nations: US

States/Provinces: CA:S3?, NV:S?, UT:S5

USFS Ecoregions: 341:C, 342B:CC

\section{ELEMENT SOURCES}

Authors: WCS Confidence: 2 Identifier: CEGL001357

References: Brotherson et al. 1986, Dastrup 1963, Graham 1937, Young et al. 1986 


\title{
V.A.5.N.c. Medium-tall sod temperate or subpolar grassland
}

\section{V.A.5.N.c.29. HESPEROSTIPA COMATA - BOUTELOUA GRACILIS HERBACEOUS ALLIANCE}

\author{
Needle-and-Thread - Blue Grama Herbaceous Alliance
}

\begin{abstract}
Alliance Concept
Summary: This alliance is widespread across upland sites in the northern Great Plains. Its communities tend to be the climax communities on fertile dry-mesic sites across much of its range. It is dominated by mid and short grass species; woody species do not regularly achieve prominence. Few of the species exceed $1 \mathrm{~m}$ while many, including Bouteloua gracilis, do not exceed $50 \mathrm{~cm}$. The most abundant species are Hesperostipa comata (= Stipa comata) and Bouteloua gracilis. On more mesic sites Hesperostipa comata is predominant, while on areas that are drier or subject to light grazing Bouteloua gracilis takes precedence. Other graminoid species that are commonly found in communities of this alliance are Aristida purpurea var. longiseta (= Aristida longiseta), Carex duriuscula (= Carex eleocharis), Carex filifolia, Koeleria macrantha, Nassella viridula, and Pascopyrum smithii. Sites in the southern half of the range of this alliance may have significant amounts of Bouteloua curtipendula. Forbs are common but not usually abundant. Forb species that are regularly found are Artemisia frigida, Gaura coccinea, Gutierrezia sarothrae (= Gutierrezia diversifolia), Liatris punctata, Sphaeralcea coccinea (= Malvastrum coccineum), Phlox hoodii, and Sphaeralcea coccinea. The clubmoss Selaginella densa is present in many stands in this alliance. Scattered shrubs are sometimes present. These include Prunus virginiana, Rhus aromatica, and Symphoricarpos occidentalis. In the western and southwestern portions of its range, Cercocarpus montanus may be found where this alliance occurs on slopes.
\end{abstract}

Communities in this alliance are found on flat to moderately steep topography. The soils are sandy loam, loam, or sometimes clay loam. They are often well-developed and derived from either glacial deposits or sometimes limestone or sandstone (Hanson and Whitman 1938, Coupland 1950, Hanson 1955).

Environment: Grasslands included in this alliance are common in the west-central and northwestern Great Plains. Elevations range from $600-2350 \mathrm{~m}$. Climate is temperate, continental and semi-arid to subhumid. Mean annual precipitation ranges from $25-50 \mathrm{~cm}$. The year-to-year variation is great, in both total annual precipitation and the proportion of precipitation occurring in the winter and spring versus summer.

Stands typically occur on upland sites in rolling plains, breaks, foothills, plateaus, xeric montane parklands and in smaller forest openings in mountains. Sites are flat to moderately steep slopes on any aspect. Soils are shallow to moderately deep, non-saline, often calcareous and alkaline, with sandy loam, loam or sometimes clay loam texture. Mountain substrates are typically coarser colluvial soils. Parent materials often include limestone, sandstone, or shale with glacial deposits in the northern Great Plains, and colluvium derived from granite, gneiss schist in the mountains.

Adjacent stands in the plains are often grasslands dominated by Pascopyrum smithii in mesic bottomlands and Bouteloua gracilis in the xeric plains and Festuca idahoensis in the mountains, shrublands dominated by Artemisia tridentata, Ribes spp. or Rhus trilobata, and woodlands dominated by Pinus edulis, Pinus flexilis, Pinus ponderosa or Juniperus spp.

Vegetation: These grasslands are widespread across upland sites in the northern Great Plains. Communities tend to be the late seral communities on fertile dry-mesic sites across much of its range (Tolstead 1941, Hansen et al. 1984). It is dominated by mid- and shortgrass species; woody species do not regularly achieve prominence. Few of the species exceed $1 \mathrm{~m}$ while many, including Bouteloua gracilis, do not exceed $50 \mathrm{~cm}$. The most abundant species are Hesperostipa comata (= Stipa comata) and Bouteloua gracilis. On more mesic sites Hesperostipa comata is predominant, while on areas that are drier or subject to light grazing Bouteloua gracilis takes precedence. Other graminoid species that are commonly found in communities of this alliance are Aristida purpurea var. longiseta (= Aristida longiseta), Carex duriuscula (= Carex eleocharis), Carex filifolia, Carex inops ssp. heliophila, Koeleria macrantha, Nassella viridula, Pascopyrum smithii or Poa secunda. Sites in the southern half of the range of this alliance may have significant amounts of Bouteloua curtipendula. Forbs are common but not usually abundant ( $<10 \%$ cover). Forb species that are regularly found are Antennaria parvifolia, Artemisia frigida, Allium textile, Eriogonum umbellatum, Gaura coccinea, Heterotheca villosa, Liatris punctata, Sphaeralcea coccinea (= Malvastrum coccineum), Phlox hoodii, Packera fendleri (= Senecio fendleri), and Sphaeralcea coccinea. The clubmoss Selaginella densa is present in many stands in this alliance (Coupland 1950, DeVelice and Lesica 1995, Hansen et al. 1984). Scattered shrubs and dwarf-shrubs are sometimes present. These may include Artemisia frigida, Gutierrezia spp., 
Krascheninnikovia lanata, Prunus virginiana, Rhus trilobata, Rosa spp., and Symphoricarpos occidentalis. In the western and southwestern portions of its range, Cercocarpus montanus may be found where this alliance occurs on slopes (Hanson 1955).

Dynamics: These mixed grasslands occur in the subhumid/semi-arid steppes in the western Great Plains where high variability of precipitation, both seasonally and yearly allows both short and mid grasses to co-exist (Coupland 1992a).

Hesperostipa comata will decline with overgrazing, leaving the more grazing-tolerant Bouteloua gracilis to dominate (Laurenroth et al. 1994, Smoliak 1965, Smoliak et al. 1972).

Fire also can change the species composition of these grasslands. Burning generally kills or severely damages Hesperostipa comata plants. After fire, regeneration of this non-rhizomatous bunchgrass is through seed and may take many years to reach prefire densities (FEIS 1998). Burning Bouteloua gracilis during the growing season will topkill the plant, but the rhizomes are usually unharmed and quickly regrow (FEIS 1998). Bouteloua gracilis is usually unharmed by fires in years with above normal winter and spring precipitation (soil moisture prevents lethal soil temperatures), but it can be severely damaged by fires that occur during drought years (FEIS 1998).

Exotic species such as Taraxacum officinale, Medicago sativa, Melilotus officinalis or Salsola kali are present in some stands.

\section{Alliance Distribution}

Range: This alliance is found in the western Great Plains, from western Kansas to North Dakota, west into Colorado, Wyoming and Montana. The alliance also extends north into Canada in Saskatchewan, Manitoba, and probably Alberta.

Nations: CA US

States/Provinces: AB CO KS MB MT ND NE SD SK WY

USFS Ecoregions: 251Ab:CCC, 251Ba:CCC, 331C:CC, 331D:CC, 331E:C?, 331F:CC, 331G:CC, 331H:CC, 331I:CC, 332C:CC, M331A:CC, M331H:CC, M331I:CC, M332B:CC, M332C:CC, M332D:CC, M332E:CC

\section{Alliance Sources}

Authors: MCS, MOD. M.S. REID, MCS Identifier: A.1234

References: Aldous and Shantz 1924, Badaracco 1971, Bear Creek Uranium Mine Application n.d., Clements and Goldsmith 1924, Comer et al. 1999, Cooper et al. 1995, Cotter-Ferguson Project n.d., Coupland 1950, Coupland 1992a, Davis 1959, DeVelice et al. 1995, Faber-Langendoen et al. 1996, Fire Effects Information System (FEIS) 1998, Hansen 1985, Hansen and Hoffman 1988, Hansen et al. 1984, Hanson 1955, Hanson 1957, Hanson and Dahl 1956, Hanson and Whitman 1938, Hardy Ranch Mine Application n.d., Hess 1981, Hubbard 1950, Johnston 1987, Kuchler 1964, Laurenroth et al. 1994, Livingston 1947, Moir 1969, Mueggler and Stewart 1980, Ramaley 1916, Smoliak 1965, Smoliak et al. 1972, Soil Conservation Service 1978, Stearns-Roger Inc. 1978, Stoecker-Keammerer Consultants n.d.(a), Tolstead 1941, Trammell and Trammell 1977, Vestal 1914, Weaver and Albertson 1956

\section{HESPEROSTIPA COMATA - BOUTELOUA GRACILIS - CAREX FILIFOLIA HERBACEOUS VEGETATION Needle-and-Thread - Blue Grama - Threadleaf Sedge Herbaceous Vegetation Needle-and-Thread - Blue Grama Mixedgrass Prairie}

\section{ELEMENT CONCEPT}

Summary: This needlegrass - grama grass prairie community is common in the northern and central Great Plains of the United States. Stands occur on flat to rolling topography with deep $(40-100 \mathrm{~cm})$, sandy loam to loam, coarser-textured soils. They are typically associated with uplands, though they may also occur lower in the landscape, such as coulee and draw bottoms, if soils are sufficiently coarse (usually sandstone-derived). The type is found at elevations ranging from 600-1700 m (2000-5500 feet); average annual precipitation associated with these elevation param ranges from slightly less than $25 \mathrm{~cm}$ to over $50 \mathrm{~cm}$ (10-20 inches). The vegetation is dominated by moderate to moderately dense medium-tall grasses. Hesperostipa comata (= Stipa comata) is the tallest of the dominant species, sending seed heads to a maximum height of approximately 1 $\mathrm{m}$. The rhizomatous graminoids Bouteloua gracilis and Carex filifolia, the other two dominant/codominant species, do not usually exceed $0.5 \mathrm{~m}$. Calamovilfa longifolia is often found with high cover values on sandier soils, and Koeleria macrantha cover increases on degraded sites. There are regionalized expressions of variability with Carex inops ssp. heliophila 
surpassing Carex filifolia in Colorado and Calamagrostis montanensis being at least as important as the diagnostic species in north-central Montana. Pascopyrum smithii is consistently present. For woody species, subshrub forms (Artemisia frigida, Gutierrezia sarothrae, Rosa arkansana) have the highest cover and constancy, but their total cover does not sum to more than 5\%, except on overgrazed sites. Cover values for forbs are low (the exception being Selaginella densa). Geographic setting influences forb composition to some degree, with Sphaeralcea coccinea, Phlox hoodii, Heterotheca villosa, Gaura coccinea, and Liatris punctata common in the northern areas, and Lygodesmia juncea, Opuntia polyacantha, Artemisia dracunculus, and Ratibida columnifera seeming to increase to the eastern and southern areas.

Environment: Stands occur on flat to rolling topography with deep $(40-100 \mathrm{~cm})$ sandy loam to loam soils. They are typically associated with uplands, though they may also occur lower in the landscape, such as coulee and draw bottoms, if soils are sufficiently coarse (usually sandstone derived). Even though it is a major association in the Northern Plains, it does not occur in areas dominated exclusively by shale and mudstone parent materials, from which heavy soils are derived. This type is found at elevations ranging from 600 to $1700 \mathrm{~m}$ (2000-5500 feet); average annual precipitation associated with these elevation parameters ranges from slightly less than $25 \mathrm{~cm}$ to over $50 \mathrm{~cm}$ (10 to 20 inches).

Vegetation: The vegetation is dominated by moderately dense graminoids that are usually between 0.5 and $1 \mathrm{~m}$ tall. For example, on 19 stands in west-central Montana the cover by the different strata was as follows: shrubs 6\%, graminoids $67 \%$, forbs $11 \%$, bryophytes 14\%, litter 55\%, rock 4\%, bare soil 9\% (Mueggler and Stewart 1978). Thilenius et al. (1995) found that the average cover on 14 stands in eastern Wyoming was $42 \%$. Hesperostipa comata (= Stipa comata) is the tallest of the dominant species, sending seed heads to a maximum height of approximately $1 \mathrm{~m}$. The rhizomatous graminoids Bouteloua gracilis and Carex filifolia, the other two dominant/codominant species, do not usually exceed $0.5 \mathrm{~m}$. Calamovilfa longifolia is often found with high cover values on sandier soils and Koeleria macrantha cover increases on degraded sites. There are regionalized expressions of variability with Carex inops ssp. heliophila surpassing Carex filifolia in Colorado and Calamagrostis montanensis being at least as important as the diagnostic species in north-central Montana. Pascopyrum smithii is consistently present. For woody species, subshrub forms (Artemisia frigida, Gutierrezia sarothrae, Rosa arkansana) have the highest cover and constancy but their total cover does exceed more than 5\%, except on overgrazed sites. Cover values for forbs are low throughout the range of the type (the exception being Selaginella densa). Geographic setting does influence forb composition to some degree. Sphaeralcea coccinea, Phlox hoodii, Heterotheca villosa, Gaura coccinea, and Liatris punctata, have high constancy values in northern areas, whereas in the eastern and southern portions of the range Lygodesmia juncea, Opuntia polyacantha, Artemisia dracunculus and Ratibida columnifera seems to be more constant.

Dynamics: Vast (singly and in the aggregate) prairie dog (Cynomys ludovicianus) "towns" once developed on the favorable substrates of this type and exploited its vegetation. Prairie dog populations have undergone a precipitous decline since settlement, so much of this type could be in various states of secondary succession, returning from a somewhat denuded state and altered composition created by the prairie dogs (and attendant bison that found nutritious forage here). Fire, both aboriginal- and lightening-caused, was a regular part of this landscape. Fire-return intervals have been considerably lengthened since settlement by European-Americans.

This association and Pascopyrum smithii - Bouteloua gracilis - Carex filifolia Herbaceous Vegetation (CEGL001579) could be considered the most common plant associations in the Northern Great Plains (Martin et al. 1998). These two associations, cited by many authors as the climatic climax communities for this region, are manifested by matrix or large patch occurrences frequently found dominating whole landscapes. The Hesperostipa comata (= Stipa comata) defined community is more associated with uplands and the Pascopyrum smithii defined type characterizes sites with higher moisture status, generally occurring at lower positions in the landscape.

\section{Similar Associations:}

- Pascopyrum smithii - Hesperostipa comata Central Mixedgrass Herbaceous Vegetation (CEGL002034)

- Bouteloua gracilis - Buchloe dactyloides Xeric Soil Herbaceous Vegetation (CEGL002270)--On degraded sites, or on intermediate habitats, this type can be confused with CEGL002037.

\section{Synonymy:}

- Stipa comata - Carex filifolia Habitat Type (Hansen et al. 1984) =

- Gramagrass - Needlegrass - Sedge (Hanson and Whitman 1938) =

- Stipa-Boutleoua $($ Hubbard 1950) $=$

- Bouteloua-Stipa (Hubbard 1950) =

- Stipa comata / Bouteloua gracilis Plant Association (Johnston 1987) B

- Stipa comata / Carex filifolia Plant Association (Johnston 1987) =

- Association Rumicetum venosi, subassoc. Boutelouetsum $($ Looman 1980) $=$

- Mixed prairie (Tolstead 1941) B 
GRank \& Reasons: G5 (99-02-25). This is an exceedingly common type, manifesting any number of permutations, some of which are related to disturbance and some of which appear to be related to the expected geographic distinctions in such a broadly distributed type. The only reason to consider it a G4 is that it has received, and continues to receive, significant grazing pressure which, combined with the surge in alien weed populations, pose a significant threat to its quality.

\section{High-ranked species:}

Comments: Carex filifolia is lacking or highly reduced in importance southward. Southern stands were once classified separately (CEGL001699), and further review of their characteristics compared to more northern stands is needed. Weaver and Albertson (1956) also remark on the fact that low sedges are present as far south as Texas but are important only north of Colorado. However, a phase of the Stipa comata - Bouteloua gracilis type of Mueggler and Stewart (1980) in western Montana is apparently quite similar to communities of the southern and southeastern portions or the Northern Great Plains, and both lack Carex filifolia. There are a welter of named community types, mostly seral representations of grazing or fire impacts, that vary by having one or another of the defining species (or even other graminoids, e.g., Carex inops ssp. heliophila) dominant. This assemblage of types is also defined by having relatively low cover of both Pascopyrum smithii and Elymus lanceolatus (= Agropyron dasystachyum). To accommodate these permutations within the concept of the type (as lesser-ranked occurrences) or to recognize them as independent vegetation types recognized by existing vegetation composition is one question. Another is, what cover value or degree of dominance of Pascopyrum smithii or Elymus lanceolatus will serve to establish the distinction between Pascopyrum smithii - Stipa comata - Carex filifolia (and allied Pascopyrum smithii-"dominated" communities) from the community under consideration.

\section{ELEMENT DISTRIBUTION}

Range: This needlegrass - grama grass prairie community is common in the northern and central Great Plains of the United States and Canada, ranging from Manitoba west to Alberta, south to Kansas and possibly Colorado.

Nations: CA US

States/Provinces: AB:S?, CO?, KS:S?, MB:S3, MT:S?, ND:S3?, NE:S?, SD:S?, SK:S?, WY:S3

USFS Ecoregions: 251Ab:CCC, 251Ba:CCC, 331C:CC, 331E:C?, 331F:CC, 331G:CC, 331H:CC, 332C:CC, M334A:CC

\section{ELEMENT SOURCES}

Authors: J. Drake, MCS Confidence: 1 Identifier: CEGL002037

References: Hansen et al. 1984, Hanson and Whitman 1938, Hubbard 1950, Johnston 1987, Looman 1980, Mueggler and Stewart 1978, Mueggler and Stewart 1980, Steinauer and Rolfsmeier 2000, Thilenius et al. 1995, Tolstead 1941, Tolstead 1942, Weaver and Albertson 1956 


\section{V.A.5.N.c.27. PASCOPYRUM SMITHII HERBACEOUS ALLIANCE Western Wheatgrass Herbaceous Alliance}

\section{ALliance CONCEPT}

Summary: This alliance is common and widespread in the Great Plains, especially the northern portions, and parts of the Great Basin. The communities in it range from dry or dry-mesic to wet-mesic. Mid grasses are the dominant vegetation in most communities, although short grasses and sedges can be codominant. The vegetation tends to be denser where the mid grasses are predominant and more open where shorter graminoids are abundant. The mid grasses grow to $0.5-1.0 \mathrm{~m}$ on favorable sites, while the short grasses and sedges are less than $0.5 \mathrm{~m}$ tall. The most abundant midgrass is Pascopyrum smithii. Common associates include Hesperostipa comata (= Stipa comata), Nassella viridula, Koeleria macrantha, Schizachyrium scoparium, Hesperostipa spartea (= Stipa spartea), and Poa spp. In the drier communities of this alliance Bouteloua gracilis is the most common shortgrass. Other short graminoids typically found in the drier communities include Carex inops ssp. heliophila, Carex duriuscula (= Carex eleocharis), Carex filifolia, and Bouteloua curtipendula (in the northern portion of this alliance's range), Aristida purpurea, and Buchloe dactyloides (in the southern half of this alliance's range). In the wetter communities within this alliance, Distichlis spicata, Hordeum jubatum, Elymus trachycaulus, and Iva annua are common. Forbs and shrubs are generally minor components of communities within this alliance. If shrubs are present they are rarely taller than $1 \mathrm{~m}$. Some forbs that are usually scattered about are Gaura coccinea, Sphaeralcea coccinea, Amorpha canescens, Astragalus spp., and Tragopogon dubius. Shrubs include Symphoricarpos occidentalis, Artemisia cana, Artemisia frigida, and Opuntia spp.

Communities within this alliance occur on several different soil types. The soil is most often clay or clay loam, however. it can be loam or sandy loam. In the east and central part of this alliance's range, these communities can be found on flat or rolling uplands, hillslopes, or along streams or depressions. In the western part of this alliance's range, its communities are found where local conditions are wetter than the average. This includes such areas as the base of slopes or along rivers or streams.

Environment: Grasslands included in this alliance occur across the Great Plains, on several different soil types (Hanson and Whitman 1938, Johnston 1987, USFS 1992). The soil is most often clay or clay loam, however it can be loam or sandy loam. In the eastern and central part of this alliance's range, these communities can be found on flat or rolling uplands, hillslopes, or along streams or depressions. In the western part of this alliance's range, communities are found where local conditions are wetter than the average. This includes such areas as the base of slopes or along rivers or streams (Weaver and Albertson 1956, Jones 1992).

Vegetation: This alliance is common and widespread in the Great Plains, especially the northern portions, and parts of the Great Basin. These communities range from dry or dry-mesic to wet-mesic. Mid grasses are the dominant vegetation in most communities, although short grasses and sedges can be codominant. The vegetation tends to be denser where the mid grasses are predominant and more open where shorter graminoids are abundant (e.g., Hansen and Hoffman 1988, USFS 1992). The mid grasses grow to $0.5-1.0 \mathrm{~m}$ on favorable sites, while the short grasses and sedges are less than $0.5 \mathrm{~m}$ tall (Weaver and Albertson 1956). The most abundant midgrass is Pascopyrum smithii. Common associates include Hesperostipa comata (= Stipa comata), Elymus trachycaulus, Nassella viridula, Koeleria macrantha, Schizachyrium scoparium, Hesperostipa spartea (= Stipa spartea), and Poa spp. In the drier communities of this alliance Bouteloua gracilis is the most common shortgrass. Other short graminoids typically found in the drier communities include Carex inops ssp. heliophila, Carex duriuscula (= Carex eleocharis), Carex filifolia, and Bouteloua curtipendula (in the northern portion of this alliance's range), Aristida purpurea and Buchloe dactyloides (in the southern half of this alliance's range). In the wetter communities within this alliance Distichlis spicata, Hordeum jubatum, Elymus trachycaulus, and Iva annua are common. Forbs and shrubs are generally minor components of communities within this alliance. If shrubs are present they are rarely taller than $1 \mathrm{~m}$. Some forbs that are usually scattered about are Gaura coccinea, Sphaeralcea coccinea, Amorpha canescens, Astragalus spp., and Tragopogon dubius. Shrubs include Symphoricarpos occidentalis, Artemisia cana, Artemisia frigida, and Opuntia spp.

Dynamics: Pascopyrum smithii is rhizomatous and is tolerant of moderate grazing. If severely over-grazed, Pascopyrum smithii will decline and may be replaced by less desirable warm season grasses and exotic species such as Poa pratensis.

\section{ALLiAnCE Distribution}

Range: Grasslands included in this alliance are found in the western Great Plains, from New Mexico north into Colorado, Wyoming and Montana, as well as Kansas north into Saskatchewan and Manitoba. It is also found in scattered locations in Idaho and Utah, and possibly Alberta, Canada.

Nations: CA US

States/Provinces: AB CO ID KS MB MT ND NE NM SD SK UT WY 
USFS Ecoregions: 251Aa:CCC, 315A:CC, 331D:CC, 331E:CC, 331F:CC, 331G:CC, 331H:CC, 331I:CC, 332:C, 342F:CC, M313B:CC, M331A:CC, M331F:CC, M332D:C?, M332E:CC

\begin{abstract}
Alliance SOURCES
Authors: MCS, MOD. M.S. REID, MOD., MCS Identifier: A.1232

References: Baker 1983c, Baker and Kennedy 1985, Bear Creek Uranium Mine Application n.d., Boutton et al. 1980, Branson et al. 1961, Branson et al. 1964, Branson et al. 1965, Bujakiewicz 1975, Bunin 1985, Cacek 1973, Christensen and Welsh 1963, Costello 1944, Culwell and Scow 1982, DeVelice et al. 1991, Dick-Peddie 1986, Donart et al. 1978a, FaberLangendoen et al. 1996, Hadley and Branson 1965, Hansen 1985, Hansen and Hoffman 1988, Hansen et al. 1984, Hansen et al. 1991, Hanson 1957, Hanson and Ball 1928, Hanson and Dahl 1956, Hanson and Whitman 1938, Hanson et al. 1931, Hyder et al. 1966, Johnston 1987, Jones 1992, Kahler 1973, Keammerer and Stoecker 1975, Marr and Buckner 1974, Moir 1969, Muldavin and Mehlhop 1992, Mutel 1976, Ramaley 1916, Ramaley 1919, Ramaley 1927, Ramaley 1942, Rogers 1950a, Shanks 1977, Shantz 1906, Shantz 1911, Shantz 1923, Soil Conservation Service 1978, Stoecker-Keammerer Consultants n.d.(b), U.S. Forest Service (USFS) 1992, Vestal 1913, Vestal 1914, Vestal 1919, Weaver and Albertson 1956, Western Resources Development Corporation n.d. (a), Wooten 1980.
\end{abstract}

\title{
PASCOPYRUM SMITHII HERBACEOUS VEGETATION \\ Western Wheatgrass Herbaceous Vegetation \\ Western Wheatgrass Mixedgrass Prairie
}

\section{ELEMENT CONCEPT}

Summary: This midgrass prairie type is found in the northern and western Great Plains, Rocky Mountains, and western basins of the United States and possibly Canada. Stands occur on level to gently sloping terrain. They are sometimes found on alluvial fans. The soils are clay, clay loam, and silt loam. The dominant mixedgrass species grow to approximately $1 \mathrm{~m}$. Pascopyrum smithii may have as much as 50\% coverage. Other grasses that co-occur and may achieve local dominance are Koeleria macrantha and Poa spp. Many other species common in midgrass prairies are also found in this community. These include Artemisia ludoviciana, Bouteloua gracilis, Nassella viridula, and Hesperostipa comata (= Stipa comata). This community is similar to several others that have significant amounts of Pascopyrum smithii. Further work needs to be done to better define the diagnostic characteristics of this community.

Environment: This community occurs on flat to gently sloping topography. Soils are clay, clay loam, and silt loam. It is sometimes found on alluvial fans of small streams. The soils are deep $(40-100 \mathrm{~cm})$ and well-developed.

Vegetation: This is a midgrass community. Shrubs are rare. The dominant species grow to approximately $1 \mathrm{~m}$. Pascopyrum smithii is the only constant dominant species and may have 50\% cover. Other species such as Koeleria macrantha and Poa spp. may be locally abundant. Many other species common in midgrass prairies are also found in this community. These include Artemisia ludoviciana, Bouteloua gracilis, Nassella viridula, and Hesperostipa comata (= Stipa comata).

\section{Dynamics:}

Similar Associations:

- Pascopyrum smithii - Nassella viridula Herbaceous Vegetation (CEGL001583)

Synonymy:

- Wheatgrass (Aldous and Shantz 1924) =

- Agropyron smithii Great Basin Grassland (Baker and Kennedy 1985) =

GRank \& Reasons: G3G5Q (96-02-01).

High-ranked species:

Comments: This community is similar to several others that are dominated or codominated by Pascopyrum smithii. As currently defined, it represents a western Great Plains and foothills version of the western wheatgrass types in the central Great Plains. Further work needs to be done to refine the differences in composition and environmental characteristics. See recent descriptions by Thilenius et al. (1995, Pascopyrum smithii sodgrass steppe, a more playa-like wheatgrass type) and by Steinauer and Rolfsmeier (2000). In Nebraska, Steinauer and Rolfsmeier (2000) suggest that their stands may resemble Pascopyrum smithii - Nassella viridula Herbaceous Vegetation (CEGL001583). 


\section{ELEMENT DISTRIBUTION}

Range: This midgrass prairie type is found in the northern and western Great Plains, Rocky Mountains and western basins of the United States and possibly Canada, ranging from North Dakota and possibly Saskatchewan, south to Nebraska and Colorado, west to Utah, and north to Idaho.

Nations: CA US

States/Provinces: CO:S1?, ID:S1Q, MT:S4, NE:S?, SD:S?, SK:S?, UT:S3S5, WY:S4Q

USFS Ecoregions: 331D:CC, 331F:CC, 331G:CC, 331H:CC, 331I:CC, 342F:CC, M331A:CC, M332E:CC

\section{ELEMENT SOURCES}

Authors: Drake, J. F., WCS Confidence: 3 Identifier: CEGL001577

References: Aldous and Shantz 1924, Baker 1983c, Baker and Kennedy 1985, Bunin 1985, Christensen and Welsh 1963, Godfread 1994, Hansen et al. 1991, Marr and Buckner 1974, Ramaley 1916, Ramaley 1919, Ramaley 1942, Shanks 1977, Soil Conservation Service 1978, Steinauer and Rolfsmeier 2000, Thilenius et al. 1995 


\title{
V.A.5.N.j. Temporarily flooded temperate or subpolar grassland
}

\author{
V.A.5.N.j.22. HORDEUM JUBATUM TEMPORARILY FLOODED HERBACEOUS \\ ALLIANCE \\ Foxtail Barley Temporarily Flooded Herbaceous Alliance
}

\begin{abstract}
Alliance Concept
Summary: This alliance is found in the northern and western Great Plains and is dominated by short and medium-tall graminoids with a total vegetation cover of nearly $100 \%$. Shrubs are often absent, and forbs are present but not usually abundant. Hordeum jubatum is the dominant species. Other common species include Elymus trachycaulus, Distichlis spicata, Pascopyrum smithii, Poa arida, Poa compressa, Rumex crispus, and Sonchus arvensis.
\end{abstract}

Stands are located in lowlands with moderately to strongly saline soils. The topography is flat and the soils are often briefly flooded or saturated in the spring.

Environment: Stands included in this alliance have been reported from lowlands across the northern Great Plains. The climate is semi-arid continental with mean annual precipitation of 25-48 cm. Elevation ranges from 750-1250 m. The topography is flat and the soils are often briefly flooded or saturated in the spring (Redmann 1972). It is also found in the drawdown zone of ponds with moderately saline water (Hansen et al. 1995). Soils are clay loam to clay and poor to very poorly drained. Soil salinity is somewhat variable. Wilson (1967) found Hordeum jubatum grew best in non-saline soils in laboratory conditions. In the field with competition, this grass grew best in moderately saline conditions (up to $0.7 \%$ salinity). The soil surface may be covered with white salt crusts with moderately to strongly saline soils (Barnes 1978, Wilson 1967, Ungar 1969, Hansen et al. 1995). Adjacent wetter sites are often open water, while surrounding uplands can be dominated by a variety of grasslands or shrublands.

Vegetation: Grasslands included in this alliance are found in lowland sites in the northern and western Great Plains. The vegetation is a sparse to dense layer of short and medium-tall graminoids dominated by the cool-season, short-lived, perennial bunchgrass Hordeum jubatum. It often occurs in nearly pure stands. Ungar (1969) described one stand that was dominated by Hordeum jubatum in the spring and early summer, then became dominated by Iva annua in the late summer. Total vegetation cover is usually high, but can range from $20 \%$ to nearly $100 \%$ (Barnes 1978, Hansen et al. 1995). Shrubs are often absent and forbs are present, but not usually abundant. Species diversity is typically low. Other species include Chenopodium spp., Distichlis spicata, Eleocharis spp., Elymus trachycaulus, Iva annua, Pascopyrum smithii, Poa arida, Poa compressa, Puccinellia nuttalliana, Rumex crispus, Salicornia rubra, and Schoenoplectus maritimus (= Scirpus paludosus).

Dynamics: Hordeum jubatum is a common, short-lived pioneer species of mesic prairie habitats where permanent grass cover has been destroyed (Dodd and Coupland 1966). It may represent a seral stage that will be taken over by more permanent grasses (Hansen et al. 1995). It is moderately salt-tolerant and can densely colonize areas disturbed by flooding along drainages, around playas and more permanent ponds. Hordeum jubatum is moderately tolerant of salinity. Often on playas, these grasslands occupy a zone of intermediate salinity between halophytic vegetation dominated by Distichlis spicata, Puccinellia nuttalliana, or Salicornia rubra, and non-saline, mesic prairie vegetation dominated by Pascopyrum smithii, Poa spp. or Elymus spp. Total vegetation cover (density and height), species composition and soil salinity depend on the amount and timing of precipitation and flooding. Growth-inhibiting salt concentrations are diluted when the soil is saturated, allowing the growth of less salt-tolerant species and more robust growth (Ungar 1967).

\section{Alliance Distribution}

Range: This alliance is found in the northern and western Great Plains. It ranges from Colorado to Montana and the Dakotas, then into southern Saskatchewan in Canada. It is likely that it occurs elsewhere in western North America, but is little reported in the literature.

Nations: CA US

States/Provinces: CO MT ND SD? SK

USFS Ecoregions: 251Aa:CCC, 331D:CC, 331E:CC, 331F:CC, 331G:CC, 332:?, M332C:CC, M332D:CC, M332E:CC

\author{
Authors: K. SCHULZ, WCS Identifier: A.1358 \\ Alliance SourCes
}


References: Baker 1984a, Barnes and Tieszen 1978, Bunin 1985, Dodd and Coupland 1966, Faber-Langendoen et al. 1996, Hansen et al. 1988, Hansen et al. 1991, Hansen et al. 1995, Redmann 1972, Reid 1974, Ungar 1967, Ungar et al. 1969, Vestal 1914

\section{HORDEUM JUBATUM HERBACEOUS VEGETATION}

Foxtail Barley Herbaceous Vegetation

Foxtail Barley Meadow

\section{ELEMENT CONCEPT}

Summary: This foxtail barley community type is found in the northern and central Great Plains of the United States and Canada, in lowlands with moderately to strongly saline soils. The topography is flat and the soils are often flooded or saturated in the spring. The vegetation is dominated by short and medium tall graminoids with a total vegetation cover of nearly $100 \%$. Shrubs are usually absent. Hordeum jubatum dominates the community. Other common species in this community are Elymus trachycaulus, Distichlis spicata, Pascopyrum smithii, Poa arida, Poa compressa, Rumex crispus, and Sonchus arvensis.

Environment: Stands are located in lowlands with moderately to strongly saline soils (Barnes 1978). The topography is flat and the soils are often flooded or saturated in the spring (Redmann 1972).

Vegetation: The vegetation is dominated by short and medium-tall graminoids with a total vegetation cover of nearly $100 \%$ (Barnes 1978). Shrubs are usually absent. Hordeum jubatum dominates the community. Other common species in this community are Elymus trachycaulus, Distichlis spicata, Pascopyrum smithii, Poa arida, Poa compressa, Rumex crispus, and Sonchus arvensis.

\section{Dynamics:}

Similar Associations:

- Distichlis spicata - Hordeum jubatum - Puccinellia nuttalliana - Suaeda calceoliformis Herbaceous Vegetation (CEGL002273)

\section{Synonymy:}

- Hordeum Type (Redmann 1972) =. uncertain if equivalent

- Foxtail Barley Community (Barnes and Tieszen 1978) =. uncertain if equivalent

GRank \& Reasons: G4 (96-02-01).

High-ranked species:

Comments: This type is poorly defined. This abstract is based on two descriptions of Hordeum jubatum-dominated stands which are assumed to be examples of this community. These stands may be variants of Distichlis spicata - Hordeum jubatum - Puccinellia nuttalliana - Suaeda calceoliformis Herbaceous Vegetation (CEGL002273). The relationship between Hordeum jubatum Herbaceous Vegetation (CEGL001798) and that type is unclear. Both communities usually contain Distichlis spicata and Hordeum jubatum in varying amounts. The presence of Puccinellia nuttalliana or Suaeda calceoliformis may be distinguishing factors. They appear to be more characteristic of strongly saline areas while Hordeum jubatum can dominate on less saline sites (Redmann 1972). Classification problems may arise on intermediate sites when Hordeum jubatum is the dominant species and Distichlis spicata, Puccinellia nuttalliana, and Suaeda calceoliformis are present in minor amounts.

\section{ELEMENT DISTRIBUTION}

Range: This foxtail barley community type is found in the northern and central Great Plains of the United States and Canada, ranging from Colorado to Saskatchewan.

Nations: CA US

States/Provinces: CO:S3?, MT:S4, ND:S?, SD?, SK:S?

USFS Ecoregions: 251Aa:CCC, 331D:CC, 331E:CC, 331F:CC, 331G:CC, 332:?, M332C:CC, M332D:CC, M332E:CC

\section{ELEMENT SOURCES}

Authors: J. Drake, WCS Confidence: 3 Identifier: CEGL001798

References: Barnes and Tieszen 1978, Bunin 1985, Hansen et al. 1991, Redmann 1972, Reid 1974, Vestal 1914 


\title{
V.A.5.N.k. Seasonally flooded temperate or subpolar grassland V.A.5.N.k.58. CAREX PRAEGRACILIS SEASONALLY FLOODED HERBACEOUS ALLIANCE Clustered Field Sedge Seasonally Flooded Herbaceous Alliance
}

\begin{abstract}
Alliance Concept
Summary: Vegetation types within this seasonally flooded, temperate or subpolar grassland alliance occur in wet meadows and moist swales and adjacent to seeps, springs, and stream channels in the mountains and shortgrass prairie. Elevations range from 1300-2400 m. Sites range from wet meadows that are often alkaline to peat-accumulating fens. The majority of the sites are relatively flat (1-4\% slope). Soils are variable. Some sites have fairly deep soils that range from heavy clays to sandy clay loams with mottling. Sites near seeps or springs have peaty soils, up to $60 \mathrm{~cm}$ deep. Surface water is typically present for extended periods well into the growing season. The water table is usually near the soil surface. Carex praegracilis dominates the graminoid stratum with up to $100 \%$ cover. Stands on drier sites form narrow bands with $25-30 \%$ cover. Other graminoid species include Calamagrostis stricta, Carex aquatilis, Carex simulata, Carex utriculata, Deschampsia caespitosa, Eleocharis palustris, and Juncus balticus. The forb stratum is present with up to $30 \%$ cover; species include Cicuta douglasii and Senecio hydrophilus. Adjacent vegetation includes patches of Carex nebrascensis and Pascopyrum smithii (= Agropyron smithii) on the prairie and Salix spp. shrublands in the mountains.
\end{abstract}

Environment: Vegetation types within this alliance occur in wet meadows and moist swales and adjacent to seeps, springs, and stream channels in the mountains and shortgrass prairie. Elevations range from 1300-2400 m. Sites range from wet meadows that are often alkaline to peat-accumulating fens. The majority of the sites are relatively flat (1-4\% slope).

Soils are variable. Some sites have fairly deep soils that range from heavy clays to sandy clay loams with mottling. Sites near seeps or springs have peaty soils, up to $60 \mathrm{~cm}$ deep. Surface water is typically present for extended periods well into the growing season. The water table is usually near the soil surface. Adjacent vegetation includes patches of Carex nebrascensis and Pascopyrum smithii (= Agropyron smithii) on the prairie and Salix spp. shrublands in the mountains.

Vegetation: Vegetation types within this alliance are classified as seasonally flooded temperate or subpolar grasslands. Carex praegracilis dominates the graminoid stratum with up to $100 \%$ cover. Stands on drier sites form narrow bands with 25-30\% cover. (Kittel et al. 1999). Other graminoid species include Calamagrostis stricta, Carex aquatilis, Carex simulata, Carex utriculata, Deschampsia caespitosa, Eleocharis palustris, and Juncus balticus. The forb stratum is present with up to 30\% cover; species include Cicuta douglasii and Senecio hydrophilus.

\section{Dynamics:}

\section{Alliance Distribution}

Range: This alliance is found in Montana, Wyoming, Colorado, and New Mexico. Carex praegracilis is widespread through the western United States and the Great Plains, and has a range from British Columbia to Manitoba, Canada, and northern Michigan and south to California, Texas, and Iowa (Hermann 1970, Cronquist et al. 1977). Stands of the alliance may occur in this larger area.

Nations: CA MX US

States/Provinces: CA? CO ID MT OR UT WA WY

USFS Ecoregions: 342C:CC, 342D:CC, M242C:CC, M331A:CC, M331D:CC, M331H:CC, M331I:CC, M333C:CC

Authors: D. CULVER, WCS Identifier: A.1419

ALLIANCE SOURCES

References: Brotherson and Barnes 1984, Cronquist et al. 1977, Culver and Sanderson 1997, Durkin et al. 1994, Hansen et al. 1988, Hermann 1970, Jones and Walford 1995, Kittel et al. 1997, Kittel et al. 1999 


\title{
CAREX PRAEGRACILIS HERBACEOUS VEGETATION
}

\author{
Clustered Field Sedge Herbaceous Vegetation
}

\section{ELEMENT CONCEPT}

Summary: This plant association forms meadows in swales and along stream channels in the prairies of several western states (Montana, Idaho, Wyoming, Colorado) on both sides of the Continental Divide. In Montana it is found at elevations as low as 2000 feet. The association occurs along small, shallow streams, usually no more than 2-5 m (7-17 feet) wide, with little sinuosity, low gradient and little to no floodplain development. Soils are deep, ranging from heavy clays to sandy clay loams. Often the only vegetation type along small streams, it completely covers the ground in narrow bands following the streambed and dominated by Carex praegracilis (20-40\% cover), Eleocharis palustris, and Equisetum laevigatum. Alternatively, it can occur in patches within a mosaic of monotypic stands of wet meadow graminoid species including Juncus balticus, Carex nebrascensis, Carex pellita (= Carex lanuginosa), and Schoenoplectus pungens (= Scirpus pungens). No shrubs or trees are present.

\section{Environment:}

\section{Vegetation:}

\section{Dynamics:}

\section{Similar Associations:}

- Carex praegracilis - Carex aquatilis Herbaceous Vegetation (CEGL001821) Synonymy: GRank \& Reasons: G3G4 (01-02-05). This association is known from several western states, although few stands have been well-documented. Stands are small meadows in Colorado (1-20 acres), but it is known to form large meadows in southwestern Montana. Occurrences on federal lands are often in a degraded condition. The highest conditions exist on unprotected private lands. Soil compaction and compositional shifts from grazing and heavy recreational use are the greatest threats. The global rank was changed from G2 to G3G4 to reflect the wide distribution of the type as well as its apparent abundance in several states (Montana and Wyoming).

High-ranked species:

Comments: This association is known from several western states (MT, ID, WY, CO), although few stands have been welldocumented. This type needs to be compared with Carex praegracilis - Carex aquatilis Herbaceous Vegetation (CEGL001821), as they are probably the same type.

\section{ELEMENT DISTRIBUTION}

Range: The plant association occurs in appropriate habitat across the Rocky Mountain and northern Great Basin states. Nations: US

States/Provinces: CO:S2, ID:S2, MT:S3S4, WY:S3S4

USFS Ecoregions: M331A:C?, M331G:CC, M331H:CC, M331I:CC, M332D:C?, M332E:C?, M333C:CC

Authors: WCS Confidence: 2 Identifier: CEGL002660

ELEMENT SOURCES

References: Culver and Sanderson 1997, Hansen et al. 1995, Jones and Walford 1995, Kittel et al. 1997, Kittel et al. 1999 


\title{
V.A.5.N.k.47. DESCHAMPSIA CAESPITOSA SEASONALLY FLOODED HERBACEOUS ALLIANCE
}

\author{
Tufted Hairgrass Seasonally Flooded Herbaceous Alliance
}

\begin{abstract}
Alliance Concept
Summary: Plant associations included in this alliance are circumboreal and are common in alpine, wet meadows and wetland margin habitats. Stands are found in moist, low-gradient valley bottoms and along streams throughout the mountainous areas of the western U.S. Typically, communities occur in areas of abundant snowfall where snowmelt saturates soils from late spring through early summer. Communities occur in the alpine tundra in snowmelt basins and around the edges of alpine wetlands. At lower elevations, the communities are typically wetlands, requiring wet or moist soils throughout most of the growing season. Soils are variable. Fine-textured soils retain soil moisture longer in areas of seasonal drought, and coarse substrates allow aeration in areas with perennial high water tables. This vegetation is characterized by a moderately dense to dense herbaceous layer dominated by the perennial bunchgrass Deschampsia caespitosa. Commonly associated graminoid species include Carex nebrascensis, Carex microptera, Carex aquatilis, Juncus balticus, Phleum alpinum, Danthonia intermedia, and Agrostis scabra. Common forbs include Geum rossii, Ligusticum tenuifolium, Polygonum bistortoides, and Caltha leptosepala. Diagnostic of this herbaceous alliance is the dominance or codominance of Deschampsia caespitosa and the presence of surface water for extended periods during the growing season.
\end{abstract}

Environment: Plant associations within this alliance are circumboreal and occur in moist, low-gradient valley bottoms throughout the mountainous areas of the western United States at elevations ranging from 800-3500 m. Deschampsia caespitosa associations require relatively cool, moist conditions. Typically, communities occur in areas of abundant snowfall where snowmelt saturates soils from late spring through early summer. The vegetation occurs at higher elevations in the southern part of its range and in dry interior locations. Communities occur in the alpine tundra in Utah and Colorado where stands grow in snowmelt basins and around the edges of alpine wetlands. At lower elevations, the communities are typically wetlands, requiring wet or moist soils through most of the growing season. Soils are diverse. In perennially wet soils, stands of this alliance occur on sand or gravel lenses which allow adequate aeration of roots. In sites with seasonal drought, the vegetation generally occurs on finer-textured soils which drain slowly and retain moisture.

Vegetation: Associations within the Deschampsia caespitosa Seasonally Flooded Herbaceous Alliance (A.1408) are common alpine, wet meadow, or wetland margin types in mountain habitats of the west (Padgett et al. 1989). The vegetation is typified by a lush growth of Deschampsia caespitosa, a perennial bunchgrass which forms an open canopy of culms and nodding panicles. Commonly associated graminoid species include Carex nebrascensis, Carex microptera, Carex aquatilis, Juncus balticus, Phleum alpinum, Danthonia intermedia, and Agrostis scabra (Johnson and Simon 1987, Hess and Wasser 1982, Padgett et al. 1989). Common forbs include Geum rossii, Ligusticum tenuifolium, Polygonum bistortoides, and Caltha leptosepala. The vegetation often occurs adjacent to perennially saturated sedge wetlands dominated by Carex utriculata, Carex aquatilis, Carex simulata, and others. Associations of this alliance generally grade into drier meadows of forbs (Senecio integerrimus, Achillea millefolium, and others) and grasses (Festuca, Muhlenbergia, Poa spp.).

Dynamics: Associations within this alliance are adapted to moist and wet soils which are seasonally flooded by snowmelt and retain moisture throughout the growing season. However, stands usually occur on sites without permanent surface water. Stands appear to be tolerant of moderate intensity ground fires and late season livestock grazing (Kovalchik 1987).

\section{Alliance Distribution}

Range: This alliance is found in wet, cold-winter habitats throughout the western United States. Associations have been reported from Arizona, Colorado, Utah, Idaho, Montana, Washington, and Oregon. Associations likely occur in Wyoming, New Mexico, California and Nevada, as well as elsewhere in the range of the distribution of Deschampsia cespitosa. The alliance is typically a moderate- to high-elevation type in the western United States, but occurs at lower elevations in humid regions of the Pacific Northwest. This montane forest alliance occurs in California's central Coast Ranges, the Transverse and Peninsular ranges.

Nations: MX US

States/Provinces: AZ CA CO ID MT NV? OR UT WA WY

USFS Ecoregions: 261A:CC, 331A:CC, 331D:CC, 331E:C?, 331G:CC, 341D:CC, 342B:CC, 342C:CC, 342D:CC, 342E:CC, M242A:C?, M242C:CC, M261C:CC, M261D:CC, M261E:CC, M262B:CC, M313A:CC, M331A:CC, 
M331D:CC, M331F:CC, M331G:CC, M331H:CC, M331I:CC, M331J:CC, M332A:CC, M332B:CC, M332C:CC, M332D:CC, M332E:CC, M332F:CC, M332G:CC, M333A:CC, M333B:CC, M333C:CC, M333D:CC, M341:C

Authors: D. SARR, WCS Identifier: A.1408

Alliance Sources

References: Bonham and Ward 1970, Briggs and MacMahon 1983, Buckner 1977, Cooper et al. 1995, Crowe and Clausnitzer 1997, Daubenmire and Daubenmire 1968, Franklin and Dyrness 1973, Hall 1971, Hall 1973, Hamann 1972, Hansen et al. 1988, Hansen et al. 1991, Hansen et al. 1995, Hess and Wasser 1982, Johnson 1961b, Johnson and Simon 1985, Johnson and Simon 1987, Kettler and McMullen 1996, Kovalchik 1987, Mutz and Queiroz 1983, Padgett et al. 1988b,

Padgett et al. 1989, Richard et al. 1996, Sanderson and Kettler 1996, Soil Conservation Service 1978, Terwilliger et al. 1979, Tiedemann 1972, Tuhy and Jensen 1982, Walford et al. 1997, Youngblood et al. 1985a, Youngblood et al. 1985b

\section{DESCHAMPSIA CAESPITOSA HERBACEOUS VEGETATION}

Tufted Hairgrass Herbaceous Vegetation

Tufted Hairgrass Meadow

\section{ELEMENT CONCEPT}

Summary: Community description in preparation

Environment:

Vegetation:

Dynamics:

Similar Associations:

Synonymy:

GRank \& Reasons: G4 (98-04-09).

High-ranked species:

Comments:

\section{ELEMENT DISTRIBUTION}

Range:

Nations: US

States/Provinces: AZ:S2?, CA:SR, CO:S4, ID:S3, MT:S4, NV?, OR:S2, UT:S3S4, WA:S?

USFS Ecoregions: 261A:CC, 331A:CC, 331D:CC, 331E:C?, 331G:CC, 341D:CC, 342B:CC, M242A:C?, M242C:CC, M261C:CC, M261D:CC, M261E:CC, M262B:CC, M313A:CC, M331A:CC, M331D:CC, M331F:CC, M331G:CC, M331H:CC, M331I:CC, M331J:CC, M332A:CC, M332B:CC, M332C:CC, M332D:CC, M332E:CC, M332F:CC, M332G:CC, M333A:CC, M333B:CC, M333C:CC, M333D:CC, M341:C

Authors: WCS Confidence: 2 Identifier: CEGL001599

\section{ELEMENT SOURCES}

References: Bonham and Ward 1970, Briggs and MacMahon 1983, Crowe and Clausnitzer 1997, Daubenmire and Daubenmire 1968, Franklin and Dyrness 1973, Hall 1971, Hall 1973, Hamann 1972, Hansen et al. 1988, Hansen et al. 1991, Hansen et al. 1995, Hess and Wasser 1982, Johnson and Simon 1985, Johnson and Simon 1987, Kettler and McMullen 1996, Kovalchik 1987, Mutz and Queiroz 1983, Padgett et al. 1988b, Padgett et al. 1989, Richard et al. 1996, Sanderson and Kettler 1996, Tiedemann 1972, Tuhy and Jensen 1982, Youngblood et al. 1985a, Youngblood et al. 1985b 


\title{
V.A.5.N.k.61. ELEOCHARIS PALUSTRIS SEASONALLY FLOODED HERBACEOUS ALLIANCE
}

\author{
Marsh Spikesedge Seasonally Flooded Herbaceous Alliance
}

\section{Alliance Concept}

Summary: This herbaceous wetland alliance occurs in shallow, mostly still water throughout the much of the western United States and central Great Plains, from sea level to alpine. Stands occur on a variety of landforms including lake margins, stream terraces, floodplains, gravel bars, and wet basins (cienegas). Sites are flat to gently sloping on any aspect. Soils and parent materials are variable, but often highly organic and derived from alluvium. Surface water is typically present for an extended period during the growing season, and the high water table remains high most of the year. The vegetation is characterized by a sparse to dense herbaceous layer that is dominated or codominated by Eleocharis palustris, a facultative wetland species. Because of the variety of habitats where this alliance occurs, associated species are diverse. Characteristic associates include several species of Carex, Juncus, and Scirpus, most notably Carex praegracilis and Juncus balticus. Other important graminoids are Phalaris arundinacea (= Phalaroides arundinacea), Spartina pectinata, Panicum virgatum, Deschampsia caespitosa, Distichlis spicata, and Muhlenbergia asperifolia. Forb cover is also variable, and may include Sparganium angustifolium, Lemna spp., Potamogeton spp., Berula erecta, Rorippa nasturtium-aquaticum, Pedicularis groenlandica, Rhodiola integrifolia, Caltha leptosepala, Mentha arvensis, Rumex crispus, Iris missouriensis, and Ranunculus cymbalaria. Diagnostic of this herbaceous wetland alliance is the dominance or codominance of Eleocharis palustris and the presence of surface water for extended periods during the growing season.

Environment: Plant associations included in this alliance are conspicuous, common emergent associations that occur in shallow, mostly still water throughout the western United States. Elevation ranges from sea level in California to $3050 \mathrm{~m}$ in Colorado. Stands occur on a variety of landforms including lake margins, stream terraces, floodplains, gravel bars, and wet basins (cienegas). Stands occur on sites that are flat, $1 \%$ slope with all aspects (Crowe and Clausnitzer 1997). Soils vary from Histosols to Entisols. High-elevation stands consistently occur on organic (highly sapric) soils, or on a thick organic horizon that overlays fine to coarse alluvial material. Lower elevation stands occur on fresh alluvial deposits of fine-textured loamy sands, clays, and sandy clays (Kittel et al. 1999). Soil reaction is often alkaline (Hansen et al. 1988). All sites are saturated throughout much of the growing season. Oregon stands are located on soils derived from volcanic (andesite, basalt) or sedimentary parent materials (Crowe and Clausnitzer 1997).

At higher elevation, Carex aquatilis or Carex utriculata meadows and Salix wolfii or Salix planifolia shrublands occur within the riparian mosaic. At lower elevation, Schoenoplectus pungens (= Scirpus pungens) often occurs within the stream channel while wet meadow prairies of Panicum virgatum and Sorghastrum nutans occupy the immediate streambanks and low floodplains.

Vegetation: Plant associations within this alliance are classified as seasonally flooded, temperate or subpolar grasslands. Eleocharis palustris, a facultative wetland species, dominates the graminoid stratum. Cover ranges from sparse to quite dense (10-80\%). Eleocharis palustris plant associations occur within a wide elevational range, and the species composition can be quite variable. In the Great Plains stands, co-occurring species often include Phalaris arundinacea (= Phalaroides arundinacea), Juncus balticus, Carex praegracilis, Schoenoplectus pungens (= Scirpus pungens), Panicum virgatum, Carex pellita (= Carex lanuginosa), Spartina pectinata, and Schoenoplectus americanus (= Scirpus americanus). Forb cover can also include Sparganium angustifolium, Lemna spp., and Potamogeton spp. (Kittel et al. 1999). Distichlis spicata and Muhlenbergia asperifolia codominate the graminoid layer in the cienegas (Arizona and New Mexico). Forb cover is composed of Berula erecta and Rorippa nasturtium-aquaticum, especially in stands with deep water (Cross 1991).

At higher, montane elevations other graminoids present include Carex aquatilis, Carex utriculata, Carex buxbaumii, Eleocharis rostellata, and Deschampsia caespitosa. Forb cover is typically low, but can be up to $25 \%$ in some stands. Common forb species include Pedicularis groenlandica, Rhodiola integrifolia, and Caltha leptosepala (Hansen et al. 1995, Kittel et al. 1999).

Crowe and Clausnitzer (1997) state that Eleocharis palustris is an aggressive species, typically excluding other species from establishing. In the Oregon stands, associated forbs include Mentha arvensis, Rumex crispus, Iris missouriensis, and Ranunculus cymbalaria.

Dynamics: At lower elevations Eleocharis palustris plant associations occur well within the active channel and are inundated annually. These early seral communities colonize backwater eddies and shallow edges of slow moving reaches of small and larger rivers. The stands are probably ephemeral, as the eddies and river edges are scoured out each year during 
high spring flows (Kittel et al. 1999). These communities have also been described as early seral stages by Padgett et al. (1989). Padgett et al. (1989) describe light colored soils for the sites, indicating an early phase of soil development.

Kovalchik (1987) reports that the lower elevation plant associations within this alliance frequently form seral communities in ponded sites between stream rehabilitation structures such as loose rock check dams.

In the montane zone, associations within this alliance occur in ponded sites on faster moving streams. If siltation occurs, sites may become dominated by Carex utriculata. At higher elevations, the associations appear to be stable. Stands occur near seeps on soils with deep organic layers, often sapric, and are saturated throughout the growing season.

Crowe and Clausnitzer (1997) state that Eleocharis palustris is of little to no forage value to livestock and wild ungulates. On seasonally drier sites, ungulate trampling may cause this species to increase (Snyder 1992 as cited in Crowe and Clausnitzer 1997). However, this species does provide seed forage and cover to ducks and geese (Kovalchik 1987).

\section{Alliance Distribution}

Range: This alliance occurs from Oregon to Montana, south to California, Arizona, and New Mexico. The alliance is expected to occur in eastern Washington.

Nations: CA MX US

States/Provinces: AZ CA? CO ID MT MXSO NE NM NV OR SD SK UT WA WY

USFS Ecoregions: 321A:CC, 331D:CC, 331F:CC, 331G:CC, 341A:CC, 341B:CC, 342A:CC, 342B:CC, 342C:CC, 342D:CC, 342G:CC, 342I:C?, M242C:CC, M261G:CC, M331A:CC, M331D:CC, M331E:CC, M331G:CC, M331H:CC, M331I:CC, M332A:CC, M332B:CC, M332C:CC, M332D:CC, M332E:CC, M332F:CC, M332G:CC, M333A:CC, M333B:CC, M333C:CC, M333D:CC, M341B:CC

Authors: D. CULVER, WCS Identifier: A.1422

\section{Alliance Sources}

References: Baker 1983c, Baker and Kennedy 1985, Brotherson 1987, Brotherson and Barnes 1984, Brown 1982, Bunin 1985, Cronquist et al. 1977, Cross 1991, Crowe and Clausnitzer 1997, Durkin et al. 1995, Ellis et al. 1979, Flowers 1962, Hansen et al. 1988, Hansen et al. 1991, Hansen et al. 1995, Hendrickson and Minckley 1984, Johnston 1987, Kartesz 1994, Kettler and McMullen 1996, Kittel and Lederer 1993, Kittel et al. 1994, Kittel et al. 1999, Kovalchik 1987, Kovalchik 1993, Manning and Padgett 1995, Mutel 1973, Mutel and Marr 1973, Padgett et al. 1988b, Padgett et al. 1989, Ramaley 1919a, Ramaley 1942, Reid et al. 1994, Sawyer and Keeler-Wolf 1995, Shupe et al. 1986, Stearns-Roger Inc. 1978, Stewart 1940, Sturges 1968, Youngblood et al. 1985a.

\section{ELEOCHARIS PALUSTRIS HERBACEOUS VEGETATION}

Marsh Spikerush Herbaceous Vegetation

Creeping Spikerush Wet Meadow

\section{ELEMENT CONCEPT}

Summary: This spikerush wet meadow community is found in the central Great Plains of the United States and Canada and in the western United States. Stands occur in small depressions in intermittent stream beds or depression pond that flood early in the season and dry out by summer. Stands are dominated by submersed and emergent rooted vegetation under $1 \mathrm{~m}$ tall. In northwestern Nebraska, Eleocharis acicularis and Eleocharis palustris commonly cover the bottoms of the pools and emerge above the water as the pools dry out. Ephemeral submersed aquatics, such as Callitriche palustris (= Callitriche verna), Potamogeton diversifolius and Marsilea vestita, may be present. As the pools dry out in mid summer, ephemeral annual forbs, such as Limosella aquatica and Plagiobothrys scouleri, may appear. By late summer Amaranthus californicus and Gnaphalium palustre may dominate in the lowest parts of the depression. In southwestern South Dakota, vegetation is composed of nearly homogeneous stands of Eleocharis palustris. Other emergents, such as Polygonum amphibium, Marsilea vestita, and Eleocharis ovata are occasionally found. Herbaceous cover is greater than 75\%, except in areas of deeper open water where floating and submerged aquatic plants, including Bacopa rotundifolia and Heteranthera limosa, occur.

Environment: In northwest Nebraska and southwest South Dakota, this community occurs in small depressions in intermittent stream beds and depression ponds that flood early in the season and dry out by summer. Soils are silty clay formed from weathered siltstone and shale (Steinauer and Rolfsmeier 2000). In southwestern South Dakota, the type occupies depression ponds in prairies (H. Marriott pers. comm. 1999). 
Vegetation: In northwestern Nebraska, stands are dominated by submersed and emergent rooted vegetation under $1 \mathrm{~m}$ tall. Eleocharis acicularis and Eleocharis palustris commonly cover the bottoms of the pools and emerge above the water as the pools dry out. Ephemeral submersed aquatics, such as Callitriche palustris (= Callitriche verna), Potamogeton diversifolius and Marsilea vestita, may be present. As the pools dry out in mid-summer, ephemeral annual forbs, such as Limosella aquatica and Plagiobothrys scouleri, may appear. By late summer Amaranthus californicus and Gnaphalium palustre may dominate in the lowest parts of the depression (Steinauer and Rolfsmeier 2000). In southwestern South Dakota, vegetation is composed of nearly homogeneous stands of Eleocharis palustris. Other emergents, such as Polygonum amphibium, Marsilea vestita, and Eleocharis ovata are occasionally found. Herbaceous cover is greater than $75 \%$ except in areas of deeper open water where floating and submerged aquatic plants, including Bacopa rotundifolia and Heteranthera limosa, occur $(\mathrm{H}$. Marriott pers. comm. 1999).

Dynamics:

Similar Associations:

Synonymy:

GRank \& Reasons: G5 (96-02-01).

High-ranked species:

Comments:

\section{ELEMENT DISTRIBUTION}

Range: This spikerush wet meadow community is found in the central Great Plains of the United States and Canada, and in the western United States, ranging from South Dakota northwestward to Montana and Saskatchewan, west to Washington, south to possibly California and east to Nevada.

Nations: CA US

States/Provinces: CA?, CO:S4, ID:S3, MT:S5, NE:S?, NV:SR, OR:S5, SD:S?, SK:S?, UT:S3?, WA:S?, WY:S3 USFS Ecoregions: 331D:CC, 331F:CC, 331G:CC, 341B:CC, 342A:CC, 342B:CC, 342C:CC, 342D:CC, 342G:CC, 342I:C?, M242C:CC, M261G:CC, M331A:CC, M331D:CC, M331E:CC, M331G:CC, M331H:CC, M331I:CC, M332A:CC, M332B:CC, M332C:CC, M332D:CC, M332E:CC, M332F:CC, M332G:CC, M333A:CC, M333B:CC, M333C:CC, M333D:CC, M334A:CC, M341B:CC

\section{ELEMENT SOURCES}

Authors: D. Faber-Langendoen, WCS Confidence: 1 Identifier: CEGL001833

References: Baker 1983c, Baker and Kennedy 1985, Brotherson and Barnes 1984, Bunin 1985, Ellis et al. 1979, Flowers 1962, Hansen et al. 1988, Hansen et al. 1991, Kettler and McMullen 1996, Kittel and Lederer 1993, Kittel et al. 1994, Kovalchik 1987, Kovalchik 1993, Mutel 1973, Mutel and Marr 1973, Padgett et al. 1988b, Padgett et al. 1989, Ramaley 1919a, Ramaley 1942, Stearns-Roger Inc. 1978, Steinauer and Rolfsmeier 2000, Stewart 1940, Youngblood et al. 1985a 


\section{V.A.5.N.k.49. POA SECUNDA SEASONALLY FLOODED HERBACEOUS ALLIANCE Curly Bluegrass Seasonally Flooded Herbaceous Alliance}

\section{Alliance Concept}

Summary: Stands included in this seasonally flooded grassland alliance are found in eastern Oregon's Columbia Basin and northwestern Nevada. The elevational range is from 1900-2400 m. Stands are found in flat, poorly drained floodplains and internally drained basins or historic lake basins (playas). Soils are moderately deep to deep, alkaline loams or clay loams. They are typically flooded in the spring and have a shallow water table that may drop below $1 \mathrm{~m}$ by the early summer. Upper soil horizons may be well-drained. Parent material is alluvium that may be derived from volcanic ash, rhyolite or basalt. Stands have moderately dense cover of perennial bunch grasses that are typically less than $0.5 \mathrm{~m}$ tall, but may extend up to 1 m. Poa secunda dominates or codominates the stands with Puccinellia lemmonii or Elymus elymoides. Other consistent graminoids may include Carex microptera, Hordeum brachyantherum, Muhlenbergia richardsonis, Juncus balticus, Juncus ensifolius, and Pseudoroegneria spicata. Forbs commonly found include the perennials Achillea millefolium, Arnica longifolia, Iris missouriensis, Stellaria longipes, and the annuals Montia linearis and Trifolium cyathiferum. The deciduous, succulent-leaved shrub Sarcobatus vermiculatus may occasionally occur in some stands and is typically 1-3 m tall. Estimates of plant species cover were not available. Adjacent vegetation may include fresh or saline wetlands dominated by species of Carex or Juncus. Uplands are typically shrublands dominated by Artemisia tridentata ssp. vaseyana.

Environment: Stands included in this seasonally flooded grassland alliance are found in eastern Oregon and northwestern Nevada. Elevations ranges from 1900-2400 m. The climate is temperate and semi-arid. Mean annual precipitation varies from $20-40 \mathrm{~cm}$ in the steppes, but may be over $60 \mathrm{~cm}$ at higher elevations in the Blue Mountains. A high proportion of the annual precipitation falls as snow. Summer is typically dry but may have occasional thunderstorms. Stands are found in flat, poorly drained floodplains and internally drained basins or historic lake basins (playas). Soils are moderately deep to deep, alkaline loams or clay loams. They are typically flooded in the spring and have a shallow water table that may drop below $1 \mathrm{~m}$ by the early summer. Upper soil horizons may be well-drained. Parent material is alluvium that may be derived from volcanic ash, rhyolite or basalt.

Adjacent vegetation may include fresh or saline wetlands dominated by species of Carex or Juncus. Uplands are typically shrublands dominated by Artemisia tridentata ssp. vaseyana.

Vegetation: This alliance includes grasslands that occur in floodplains of the Columbia Basin. Stands have moderately dense cover of perennial bunch grasses that are typically less than $0.5 \mathrm{~m}$ tall, but may extend up to $1 \mathrm{~m}$. Poa secunda dominates or codominates the stands with Puccinellia lemmonii or Elymus elymoides. Other consistent graminoids may include Carex microptera, Hordeum brachyantherum, Muhlenbergia richardsonis, Juncus balticus, Juncus ensifolius, and Pseudoroegneria spicata. Common forbs include the perennials Achillea millefolium, Arnica longifolia, Iris missouriensis, Stellaria longipes and the annuals Montia linearis and Trifolium cyathiferum. The deciduous, succulent-leaved shrub Sarcobatus vermiculatus may occasionally occur in some stands and is typically 1-3 m tall. Estimates of plant species cover were not available.

Dynamics: These relatively mesic grasslands are transitional between wetlands and upland vegetation communities. They are dependent on spring flooding or shallow water table for supplemental moisture in the semi-arid region where they occur, but tolerate drying of the upper soil horizons when the water table drops below $1 \mathrm{~m}$ in early summer (Manning 1988).

Blackburn et al. (1969) described Carex sp. / Taraxacum officinale Community in a meadow that is disturbed by haying and likely grazing. His report is probably a seral representative of a Poa secunda / Carex sp. habitat type. Total vegetation cover is 55\%. Dominant species are Elymus trachycaulus, Carex sp., Iris missouriensis, and Taraxacum officinale.

\section{Alliance Distribution}

Range: Grasslands in this alliance occurs in floodplains in the Columbia Basin in Oregon and Nevada. It likely occurs in California, but necessary classification is needs to be done.

Nations: US

States/Provinces: CA? NV OR

USFS Ecoregions: 341:C, 342B:CC, 342C:C?, M242C:CC, M261G:CC

\section{Alliance Sources}

Authors: K. SCHULZ, WCS Identifier: A.1410

References: Blackburn et al. 1969, Borgais 1990, Kagan 1986, Manning 1988, Reid et al. 1994, Sawyer and Keeler-Wolf 1995 
POA SECUNDA HERBACEOUS VEGETATION

Curly Bluegrass Herbaceous Vegetation

\section{ELEMENT CONCEPT}

Summary: Community description in preparation

Environment:

Vegetation:

Dynamics:

Similar Associations:

Synonymy:

GRank \& Reasons: G4? (96-02-01).

High-ranked species:

Comments:

\section{ELEMENT DISTRIBUTION}

\section{Range:}

Nations: US

States/Provinces: CA?, NV:S4, OR:S2

USFS Ecoregions: 341:C, 342B:CC, 342C:C?, M242C:CC

\section{ELEMENT SOURCES}

Authors: WCS Confidence: 2 Identifier: CEGL001657

References: Blackburn et al. 1969b, Manning 1988 


\title{
V.A.7.N.e. Medium-tall temperate or subpolar grassland with a sparse needle- leaved or microphyllous evergreen shrub layer
}

\author{
V.A.7.N.e.11. ARTEMISIA CANA SHRUB HERBACEOUS ALLIANCE \\ Silver Sagebrush Shrub Herbaceous Alliance
}

ALLiance CONCEPT

Summary: This alliance is reported from the eastern Oregon mountain ranges and basins to southwestern Montana and the northern Great Plains. Stands are found in two different environmental settings, most commonly along non-active (higher) river and stream terraces and in upland areas with sandy soils. This vegetation has a sparse shrub layer (<25\%) composed primarily of the characteristic shrubArtemisia cana, but Artemisia tridentata (usually ssp. vaseyana but occasionally ssp. tridentata), and Chrysothamnus viscidiflorus are common in some stands, as are Symphoricarpos occidentalis and Artemisia frigida. The herbaceous layer is dominated by graminoids and has more cover than the shrub layer. Dominant or important graminoids include Poa fendleriana, Calamovilfa longifolia, Hesperostipa comata (= Stipa comata), Achnatherum hymenoides (= Oryzopsis hymenoides), Pascopyrum smithii, Festuca idahoensis, Carex inops ssp. heliophila, Muhlenbergia cuspidata, Nassella viridula (= Stipa viridula), and Bouteloua gracilis. Among the typically sparse forbs that may be found are Achillea millefolium, Gaura coccinea, Sphaeralcea coccinea, Lactuca tatarica var. pulchella, Symphyotrichum campestre var. bloomeri (= Aster campestris var. bloomeri), Cirsium foliosum, and Taraxacum officinale. The vegetation in the alliance includes non-wetland plant associations dominated by Artemisia cana with less than $25 \%$ total shrub cover and an abundant herbaceous cover of medium stature.

Environment: Plant associations in this alliance occur in the northwestern Great Plains, southwestern Montana and in eastern Oregon. Elevations where it is found in the Great Plains range from 500-1000 m, in Oregon from 1060-2200 m, and in Montana over $1825 \mathrm{~m}$. Precipitation varies across the range, from less than $25 \mathrm{~cm}$ in semi-arid basins of southeastern Oregon, to over $90 \mathrm{~cm}$ in moist meadow habitats of the northern Rocky Mountains. There are two environmental settings where the associations occur. One setting is along non-active (higher) terraces of rivers and streams; the other is in upland areas on sandy soils. Most commonly, the alliance occurs as an upper terrace community along mountain streams, where soils are saturated in spring and water tables remain within 2-3 m of the soil surface all year. Topography is usually mild, soils are fine to somewhat coarse alluvial soils, and some source of subsurface moisture is often present. In Oregon, soils are deep, easily eroded alluvium with surface textures of fine sandy to silty clay loams. Available water-holding capacity is moderately high. Water tables are within 2 feet of the soil surface in May and June, dropping to 4-5.5 feet below the soil surface in July through September. In Montana, some stands occur on well-drained, often sandy, glacial drift and sandy alluvium (Comer et al. 1999). Where herbaceous growth is vigorous and decomposition rates are low due to a high water table, soils may develop organic profiles. Adjacent vegetation varies from Pinus contorta forests in the mountains, to Artemisia tridentata shrublands or Pseudoroegneria - Bouteloua mixed grasslands in semi-arid basins and plains. In riparian zones, adjacent vegetation may be dominated by Sarcobatus vermiculatus, Salix spp. shrublands and Carex spp. meadows.

Vegetation: Vegetation types in this alliance are reported from eastern Oregon mountain ranges and basins, and the northern Great Plains. Artemisia cana is the dominant shrub, forming a sparse shrub layer from $0.4-1 \mathrm{~m}$ in height. The variation in height is related to which subspecies of Artemisia cana is present in the stands. In Oregon examples of this alliance, Artemisia cana is often the only shrub, but Artemisia tridentata (usually ssp. vaseyana but occasionally ssp. tridentata), and Chrysothamnus viscidiflorus can also be common in some stands. The bunchgrass Poa fendleriana is usually the dominant herbaceous species. Other common bunch grasses include Koeleria macrantha, Elymus trachycaulus, Muhlenbergia richardsonis, and Carex praegracilis. Forbs include Achillea millefolium, Symphyotrichum campestre var. bloomeri (= Aster campestris var. bloomeri), and Cirsium foliosum.

Examples of this alliance in the northern Great Plains and southwestern Montana generally occur in a moister climate, at least during the growing season. In addition to Artemisia cana, other common shrubs include Artemisia tridentata ssp. vaseyana, Symphoricarpos occidentalis, and Artemisia frigida. Herbaceous cover is moderate, but typically exceeds the shrub cover. Bunch grasses are the dominant life forms in this layer. Any one of the following species can be dominant or important: Calamovilfa longifolia, Hesperostipa comata (= Stipa comata), Achnatherum hymenoides (= Oryzopsis hymenoides), Pascopyrum smithii, Festuca idahoensis, Carex inops ssp. heliophila, Muhlenbergia cuspidata, Nassella viridula (= Stipa viridula), and Bouteloua gracilis. Among the forbs that are typically found are Achillea millefolium, Gaura coccinea, Sphaeralcea coccinea, Lactuca tatarica var. pulchella, and Taraxacum officinale.

Dynamics: The vegetation in this alliance usually occurs on alluvial terrain which is often grazed by domestic livestock and is strongly preferred during the growing season. Prolonged livestock use can decrease the abundance of native bunch grasses and increase the cover of shrubs and non-native grass species, such as Poa pratensis and Taraxacum officinale. Unlike other 
Artemisia spp., Artemisia cana resprouts vigorously following spring fire, and prescribed burning may increase shrub cover. Conversely, fire in the fall may decrease shrub abundance.

\section{Alliance Distribution}

Range: Associations in this alliance are found in eastern Oregon, southwestern Montana, and in the northern Great Plains of Montana, Wyoming, and Alberta, Canada. The alliance is expected to occur in North Dakota and Saskatchewan, Canada. Nations: CA US

States/Provinces: AB CA? MT ND NV? OR SD SK? WY

USFS Ecoregions: 331D:CC, 331F:CC, 331G:CC, 342A:CC, 342B:CC, 342C:CC, 342E:CC, 342F:CC, 342G:CC, M242C:CC, M261G:CC, M331A:CC, M331B:CC, M331D:CC, M332D:CC, M332E:CC

Authors: D. SARR, WCS Identifier: A.1531

\section{Alliance Sources}

References: Chappell et al. 1997, Comer et al. 1999, Culwell and Scow 1982, DeVelice et al. 1991, Dealy 1971, Hansen and Hoffman 1988, Hansen et al. 1984, Hanson and Whitman 1938, Kovalchik 1987, Mueggler and Stewart 1980, Oregon Natural Heritage Program (ORNHP) n.d., Padgett 1982, Thilenius and Brown 1990, Thilenius et al. 1995, Warren n.d., Winward 1980

\section{ARTEMISIA CANA / HESPEROSTIPA COMATA SHRUB HERBACEOUS VEGETATION}

Silver Sagebrush / Needle-and-Thread Shrub Herbaceous Vegetation

Silver Sagebrush / Needle-and-Thread Shrub Prairie

\section{ELEMENT CONCEPT}

Summary: This shrub prairie association, which generally occurs in small patches (less than 1 hectare), occurs in the northwestern Great Plains. In Montana, it is found on benches to gently inclined slopes (30\% maximum recorded) in the vicinity of breaklands. Similar habitats (old river terraces, badlands, ravine sideslopes and valley walls) support its occurrence in Alberta. Sites occur on various parent materials, but mostly well-drained, often sandy, glacial drift and sandy alluvium. Artemisia cana is decidedly the dominant shrub with canopy coverages to 50\%, but averaging around $25 \%$, which places it on the cusp of being a true shrub type. Artemisia frigida is the only shrub/subshrub with greater than 50\% constancy and its cover does not exceed 3\%. A number of graminoids have high constancy, including Bouteloua gracilis, Carex filifolia, Koeleria macrantha, and Poa secunda (= Poa sandbergii), but only Hesperostipa comata (= Stipa comata) exhibits both $100 \%$ constancy and the highest cover values (averaging 38\%). Forbs constitute an insignificant component, virtually none occurring in greater than trace amounts. Those exceeding 50\% constancy are Sphaeralcea coccinea, Pediomelum argophyllum (= Psoralea argophylla), and Gaura coccinea. This association is hypothesized to represent the driest environment capable of supporting Artemisia cana. Occasional fire probably has reduced Artemisia spp. cover and density to low levels and maintains the shrub herbaceous community structure.

Environment: This type is found on benches to gently inclined slopes (30\% maximum recorded value) of rolling prairie, steeper ravine slopes, and all manner of topography in the vicinity of breaklands. It occurs on various parent materials but mostly well-drained, often sandy, glacial drift. The ground cover is highly variable with some sites (putatively overgrazed) having a sward of Selaginella densa and lichens, while others have $70 \%$ litter and trace amounts of Selaginella densa; only one plot had as much as $10 \%$ exposed soil, gravel and rock (combined cover).

Vegetation: Artemisia cana (probably Artemisia cana ssp. cana (Shultz 1984)) is decidedly the dominant shrub with canopy coverages ranging to $50 \%$ on heavily grazed sites, but averaging $27 \%$; Artemisia frigida is the only shrub/subshrub with greater than 50\% constancy and its cover did not exceed 3\%. A number of graminoids have high constancy, including Bouteloua gracilis, Carex filifolia, Koeleria macrantha, and Poa secunda (= Poa sandbergii), but only Hesperostipa comata (= Stipa comata) exhibits both $100 \%$ constancy and the highest cover values (averaging 38\%). Muhlenbergia cuspidata and Calamovilfa longifolia had rather high cover on some sites. Forbs constitute an insignificant component, occurring in trace amounts; those exceeding 50\% constancy are Sphaeralcea coccinea, Pediomelum argophyllum (= Psoralea argophylla) and Gaura coccinea. This association is hypothesized to represent the driest environment capable of supporting Artemisia cana; most often this association grades to upland range sites dominated by Hesperostipa comata (= Stipa comata) and Bouteloua gracilis and to the Artemisia cana / Pascopyrum smithii association that occupies more mesic positions on lower floodplain terraces. 
Dynamics: The relatively high cover of Artemisia cana may be the result of an altered fire regime. During presettlement time, when fires were more frequent, this type might not have attained these shrub densities.

Similar Associations:

- Artemisia cana ssp. cana / Calamovilfa longifolia Shrub Herbaceous Vegetation (CEGL001555)

- Artemisia cana ssp. cana / Pascopyrum smithii Shrub Herbaceous Vegetation (CEGL001556)

Synonymy:

- Artemisia cana - Stipa comata community type (DeVelice et al. 1995) =

- Spear Grass - Sagebrush Association (DeVelice et al. 1995) =

- Sagebrush / Needle \& Thread Site Type (DeVelice et al. 1995) F

- Sagebrush flats (DeVelice et al. 1995) B

- Artemisia cana / Bouteloua gracilis - Calamovilfa longifolia (Thilenius et al. 1995) B

- Artemisia cana ssp. cana / Calamovilfa longifolia association (Thilenius et al. 1995) B

GRank \& Reasons: G3 (99-12-06). This small patch type currently has a narrowly circumscribed geographic distribution, though it may be expected to occur in Saskatchewan and North Dakota. Habitats with the potential to support this type appear to be relatively abundant, but the type itself is comparatively uncommon. Though embedded in primarily agricultural landscapes, the proximity of this type to breaklands/badlands probably lessens the chances of its being sacrificed to the plow. This type's affinity for well drained benches and gently inclined landforms in a primarily agricultural landscape puts it at a moderate risk for agriculture conversion. Fortunately this landform also occurs in breakland and badland environments less desirable for agriculture, thus lessening the chances of this uncommon type being converted to agriculture. Its graminoid composition renders it only moderately attractive to cattle, and the scarcity of forbs decrease its value as sheep range.

\section{High-ranked species:}

Comments: In their vegetation key to this type, DeVelice et al. (1995) allow for the occasional dominance of Bouteloua gracilis and/or Calamovilfa longifolia, in lieu of Hesperostipa comata (= Stipa comata) (which is by far the usual case), to be indicative of the association. The cover of Artemisia cana ranges widely, spanning the values defining shrub herbaceous and shrubland categories. The type is described as shrub herbaceous because the preponderance of stands had cover of less than $25 \%$, though the average cover just exceeded this value. This type could probably be combined with Artemisia cana / Calamovilfa longifolia Shrub Herbaceous Vegetation (CEGL001555) without compromising the ecological information embedded in either type. This type is less moist than the Artemisia cana / Pascopyrum smithii Shrub Herbaceous Vegetation (CEGL001556), which contains rhizomatous wheatgrasses and/or Nassella viridula as dominants. In Wyoming's Cheyenne River Basin, stands of Artemisia cana / Bouteloua gracilis - Calamovilfa longifolia Shrub Herbaceous Vegetation (not in USNVC) (renamed Artemisia cana ssp. cana / Calamovilfa longifolia association by Thilenius et al. (1995), G.P. Jones pers. comm.) occur on well-drained sand dunes and lack, or have low coverages of, Pascopyrum smithii, but support Hesperostipa comata as $100 \%$ constant; Hesperostipa comata coverages approach those of the named diagnostic grasses. At least two plots of the Artemisia cana / Hesperostipa comata Shrub Herbaceous Vegetation (CEGL001553) having Calamovilfa longifolia dominant could be allocated to Artemisia cana ssp. cana / Calamovilfa longifolia Shrub Herbaceous Vegetation (CEGL001555).

\section{ELEMENT DISTRIBUTION}

Range: This association is well documented from Montana and Alberta, Canada. The same or a closely analogous type occurs in Wyoming, and some permutation of the type is to be expected in northwestern North Dakota and Saskatchewan.

Nations: CA US

States/Provinces: AB:S?, MT:S3, ND?, SK?, WY?

USFS Ecoregions: 331D:CC, 331E:CC, 331F:CP, 331G:CP, M332E:CC

\section{ELEMENT SOURCES}

Authors: S.V. Cooper and C. Jean, WCS Confidence: 1 Identifier: CEGL001553

References: DeVelice et al. 1991, DeVelice et al. 1995, Thilenius et al. 1995 


\title{
V.A.7.N.n. Intermittently flooded temperate or subpolar grassland with a sparse xeromorphic (evergreen and/or deciduous) shrub layer
}

\author{
V.A.7.N.n.1. SARCOBATUS VERMICULATUS INTERMITTENTLY FLOODED SHRUB \\ HERBACEOUS ALLIANCE \\ Black Greasewood Intermittently Flooded Shrub Herbaceous Alliance
}

\begin{abstract}
Alliance Concept
Summary: This alliance is found in the northern Great Plains and Rocky Mountain foothills. The vegetation typically has moderate to dense cover. Medium-tall (0.5-1.5 m) shrubs are scattered throughout; their total canopy cover is $10-25 \%$. The shrub layer is dominated by Sarcobatus vermiculatus, with Atriplex confertifolia, Artemisia tridentata, and Chrysothamnus viscidiflorus in smaller amounts. Symphoricarpos occidentalis and Rhus aromatica are sometimes found in more mesic microhabitats within this community. Herbaceous cover is sparse beneath the shrubs and moderate to dense in between. The dominant species are typically 0.5-1 m tall. The most abundant species is Pascopyrum smithii, usually accompanied by Bouteloua gracilis, Bromus japonicus, Bromus tectorum, and Hesperostipa comata (= Stipa comata). Few forbs are found in this community. Achillea millefolium and Opuntia polyacantha are the only species with high constancy. Overall species diversity in this community is low.
\end{abstract}

Stands in this alliance are found on flat to gently sloping alluvial fans, terraces, lakebeds, and floodplains. Sarcobatus vermiculatus has been found in association with Pascopyrum smithii only on the most arid parts of southwestern Saskatchewan. The soil is usually deep clay, silty clay, sandy clay, or loam, although coarse soils are possible. They are saline or alkaline, but salt crusts on the surface are absent (Thilenius et al. 1995). Parent material is usually alluvium. Flooding during the spring is possible.

Environment: Shrublands included in this alliance occur on lowland sites in the northwestern Great Plains and central Wyoming. Precipitation varies with geography but ranges from $25-35 \mathrm{~cm}$. Elevations range from $655-2400 \mathrm{~m}$. Stands occur on flat to gently sloping alluvial fans, terraces, lakebeds, and floodplains (Mueggler and Stewart 1978, Hansen and Hoffman 1988). Dodd and Coupland (1966) found Sarcobatus vermiculatus in association with Pascopyrum smithii only on the most arid parts of southwest Saskatchewan. Sites are poorly drained and intermittently flooded with a shallow or perched water table often within $1 \mathrm{~m}$ depth (Hansen et al. 1995). Substrates are generally shallow, fine-textured soils (clays to silt-loams), derived from alluvium, although coarse soils are possible (Hirsch 1985, USFS 1992, Jones and Walford 1995, Thilenius et al. 1995) Soils are alkaline or saline, although not strongly saline because salt crusts do not generally form (Thilenius et al. 1995)

Adjacent upland vegetation varies with geography. In the Great Plains, it is likely short- or midgrass prairie and in central Wyoming it is typically shrublands dominated by Artemisia tridentata.

Vegetation: Vegetation included in this alliance is found on intermittently flooded lowland sites such as stream terraces, swales, playas and gently sloping alluvial fans in the northern Great Plains and Rocky Mountain foothills. The vegetation typically has moderate to dense cover (Jones and Walford 1995, Thilenius et al. 1995, Walford 1996) dominated by the coolseason mid grasses. The herbaceous cover is sparse beneath the shrubs and moderate to dense between them. The dominant species are typically 0.5-1 m tall. The most abundant species is Pascopyrum smithii, usually accompanied by Bouteloua gracilis, Hesperostipa comata (= Stipa comata) and the exotics Bromus japonicus and Bromus tectorum. Medium-tall (0.5$1.5 \mathrm{~m}$ ) shrubs are scattered throughout; their total canopy is 10-25\%. The shrub layer is dominated by Sarcobatus vermiculatus, with Atriplex confertifolia, Artemisia tridentata, and Chrysothamnus viscidiflorus in smaller amounts. Symphoricarpos occidentalis and Rhus aromatica are sometimes found in more mesic microhabitats within this community (Hirsch 1985). Few forbs are found in this community. Achillea millefolium and Opuntia polyacantha are the only species with high constancy. Overall species diversity in this community is low (Hansen and Hoffman 1988).

Dynamics: Sarcobatus vermiculatus, like many facultative halophytes, is tolerant of alkaline and saline soil conditions that allow it to occur in sites with less interspecific competition (Ungar et al. 1969, Bransen et al. 1976). Sarcobatus vermiculatus is often found on sites with high water tables that are intermittently flooded. Hansen et al. (1995) reported that it can tolerate saturated soil conditions for up to 40 days. Sarcobatus vermiculatus is not ordinarily browsed, but Daubenmire (1970) found that under heavy stocking rates the shrubs will develop a compact canopy. Hansen et al. (1995) also reported browsing damage with heavy spring and summer grazing, but noted that Sarcobatus vermiculatus is moderately poisonous to livestock especially in the fall, and supplemental feed is recommended to avoid livestock loss. Hanson (1929) states that Sarcobatus 
vermiculatus can form an important part of winter forage for sheep. Fire will topkill Sarcobatus vermiculatus, but the shrub will promptly resprout from the root crown (Daubenmire 1970).

\section{Alliance Distribution}

Range: Stands included in this alliance occur on bottomland sites in the northern Great Plains from central Wyoming and western Nebraska to Montana and western North Dakota. The alliance probably extends into southern Saskatchewan.

Nations: CA US

States/Provinces: MT ND NE SD SK? WY

USFS Ecoregions: 331D:CC, 331F:CC, 331G:CC, 342A:CC, 342F:CC, 342G:CC, M332B:CC, M332D:CC, M332E:CC

Authors: K. SCHULZ, WCS Identifier: A.1554

Alliance Sources

References: Branson et al. 1976, Brown 1971, Daubenmire 1970, Dodd and Coupland 1966, Earth Resource Technology n.d., Faber-Langendoen et al. 1996, Fisser et al. 1965, Hamner 1964, Hansen and Hoffman 1988, Hansen et al. 1988a, Hansen et al. 1995, Hanson 1929, Hirsch 1985, Johnston 1987, Jones and Walford 1995, Montana Natural Heritage Program (MTNHP) 1988, Mueggler and Stewart 1978, Mueggler and Stewart 1980, Olson and Gerhart 1982, Thilenius et al. 1995, U.S. Forest Service (USFS) 1992, Ungar et al. 1969, Walford 1996

\section{SARCOBATUS VERMICULATUS / PASCOPYRUM SMITHII - (ELYMUS LANCEOLATUS) SHRUB HERBACEOUS VEGETATION \\ Black Greasewood / Western Wheatgrass - (Streamside Wild Rye) Shrub Herbaceous Vegetation Greasewood / Western Wheatgrass Shrub Prairie}

\section{ELEMENT CONCEPT}

Summary: This greasewood shrub prairie is found in saline habitats in the northwestern Great Plains of the United States and Canada. Stands occur on flat to gently sloping alluvial fans, terraces, lakebeds, and floodplains. The soil is usually deep clay, silty clay, sandy clay, or loam, although coarse soils are possible. They are saline or alkaline, but salt crusts on the surface are typically absent. Parent material is usually alluvium. This community has moderate to dense vegetation cover. Medium-tall (0.5-1.5 m) shrubs are scattered throughout with a total shrub canopy of 10-25\%. The shrub layer is dominated by Sarcobatus vermiculatus, with Artemisia tridentata, Atriplex confertifolia, and Chrysothamnus viscidiflorus in smaller amounts. Symphoricarpos occidentalis and Rhus aromatica are sometimes found in more mesic microhabitats within this community. Herbaceous cover is sparse beneath the shrubs and otherwise moderate to dense. The dominant species are typically 0.5-1 m tall. The most abundant species is Pascopyrum smithii, usually accompanied by Bouteloua gracilis, Bromus japonicus, Bromus tectorum, and Hesperostipa comata (= Stipa comata). Few forbs are found in this community. Achillea millefolium and Opuntia polyacantha are the only species with high constancy. Overall species diversity in this community is low.

Environment: This community is found on flat to gently sloping alluvial fans, terraces, lakebeds, and floodplains (Mueggler and Stewart 1978, Hansen and Hoffman 1988). Dodd and Coupland (1966) found Sarcobatus vermiculatus in association with Pascopyrum smithii only on the most arid parts of southwestern Saskatchewan. The soil is usually deep clay, silty clay, sandy clay, or loam (Hirsch 1985, Jones and Walford 1995), although coarse soils are possible (USFS 1992, Thilenius et al. 1995). They are saline or alkaline, but salt crusts on the surface are absent (Thilenius et al. 1995, but see Steinauer and Rolfsmeier 2000). Parent material is usually alluvium. Flooding during the spring is possible.

Vegetation: This community has moderate to dense vegetation cover (Jones and Walford 1995, Thilenius et al. 1995). Medium-tall (0.5-1.5 m) shrubs are scattered throughout, with a total shrub canopy of 10-25\% (Hansen and Hoffman 1988, USFS 1992). The shrub layer is dominated by Sarcobatus vermiculatus, with Atriplex confertifolia, Atriplex canescens, Atriplex argentea, Artemisia tridentata, and Chrysothamnus viscidiflorus in smaller amounts. Symphoricarpos occidentalis and Rhus aromatica are sometimes found in more mesic microhabitats within this community (Hirsch 1985). Herbaceous cover is sparse beneath the shrubs and moderate to dense in between. The dominant species are typically $0.5-1 \mathrm{~m}$ tall. The most abundant species is Pascopyrum smithii, usually accompanied by Bouteloua gracilis, Bromus japonicus, Bromus tectorum, and Hesperostipa comata (= Stipa comata). Few forbs are found in this community. Achillea millefolium and Opuntia polyacantha are the only species with high constancy. Other species present may include Grindelia squarrosa. Overall species diversity in this community is low (Hansen and Hoffman 1988, Von Loh et al. 1999). In Nebraska, shrub 
species cover may be very low, and saline pockets may contain Distichlis spicata and Sporobolus airoides. Astragalus bisulcatus may be prominent (Steinauer and Rolfsmeier 2000).

Dynamics:

Similar Associations:

- Sarcobatus vermiculatus / Elymus elymoides - Pascopyrum smithii Shrubland (CEGL001365)

- Sarcobatus vermiculatus / Distichlis spicata - (Puccinellia nuttalliana) Shrub Herbaceous Vegetation (CEGL002146)

Synonymy:

- Agropyron - Sarcobatus Community (Dodd and Coupland 1966) B

- Sarcobatus Community (Brown 1971) =. Brown (1971) appears to have grouped the Sarcobatus vermiculatus / Pascopyrum smithii Sparse Shrubland and a Sarcobatus vermiculatus / Pseudoroegneria spicata Sparse Shrubland into one Sarcobatus community. The relationship of the former two communities in the ICEC is unclear.

- Sarcobatus vermiculatus / Agropyron smithii Habitat Type (Mueggler and Stewart 1978) =. Brown (1971) appears to have grouped the Sarcobatus vermiculatus / Pascopyrum smithii Sparse Shrubland and a Sarcobatus vermiculatus / Pseudoroegneria spicata Sparse Shrubland into one Sarcobatus community. The relationship of the former two communities in the ICEC is unclear.

- Sarcobatus vermiculatus - Artemisia tridentata Habitat Type (Hirsch 1985) B. Brown (1971) appears to have grouped the Sarcobatus vermiculatus / Pascopyrum smithii Sparse Shrubland and a Sarcobatus vermiculatus / Pseudoroegneria spicata Sparse Shrubland into one Sarcobatus community. The relationship of the former two communities in the ICEC is unclear.

- Sarcobatus vermiculatus - Artemisia tridentata / Elytrigia smithii Plant Association (Johnston 1987) =. Brown (1971) appears to have grouped the Sarcobatus vermiculatus / Pascopyrum smithii Sparse Shrubland and a Sarcobatus vermiculatus / Pseudoroegneria spicata Sparse Shrubland into one Sarcobatus community. The relationship of the former two communities in the ICEC is unclear.

- Sarcobatus vermiculatus / Agropyron smithii Habitat Type (Hansen et al. 1984) =. Brown (1971) appears to have grouped the Sarcobatus vermiculatus / Pascopyrum smithii Sparse Shrubland and a Sarcobatus vermiculatus / Pseudoroegneria spicata Sparse Shrubland into one Sarcobatus community. The relationship of the former two communities in the ICEC is unclear.

- Sarcobatus vermiculatus / Agropyron smithii Habitat Type (U.S. Forest Service (USFS) 1992) =. Brown (1971) appears to have grouped the Sarcobatus vermiculatus / Pascopyrum smithii Sparse Shrubland and a Sarcobatus vermiculatus / Pseudoroegneria spicata Sparse Shrubland into one Sarcobatus community. The relationship of the former two communities in the ICEC is unclear.

- Black Greasewood/Western Wheatgrass Community (Jones and Walford 1995) =. Brown (1971) appears to have grouped the Sarcobatus vermiculatus / Pascopyrum smithii Sparse Shrubland and a Sarcobatus vermiculatus / Pseudoroegneria spicata Sparse Shrubland into one Sarcobatus community. The relationship of the former two communities in the ICEC is unclear.

- Sarcobatus vermiculatus / Agropyron smithii - Bouteloua gracilis Shrub Steppe (Thilenius et al. 1995) =. Brown (1971) appears to have grouped the Sarcobatus vermiculatus / Pascopyrum smithii Sparse Shrubland and a Sarcobatus vermiculatus / Pseudoroegneria spicata Sparse Shrubland into one Sarcobatus community. The relationship of the former two communities in the ICEC is unclear.

- Greasewood Shrub Prairie (Steinauer and Rolfsmeier 2000) =. Brown (1971) appears to have grouped the Sarcobatus vermiculatus / Pascopyrum smithii Sparse Shrubland and a Sarcobatus vermiculatus / Pseudoroegneria spicata Sparse Shrubland into one Sarcobatus community. The relationship of the former two communities in the ICEC is unclear.

GRank \& Reasons: G4 (96-02-01).

High-ranked species:

Comments: Compare this association with Sarcobatus vermiculatus / Elymus elymoides - Pascopyrum smithii Shrubland (CEGL001365) from New Mexico.

See Steinauer and Rolfsmeier (2000) for a description of the stands in Nebraska. Sarcobatus vermiculatus / Distichlis spicata - (Puccinellia nuttalliana) Shrub Herbaceous Vegetation (CEGL002146) may be a more saline version of this type.

\section{ELEMENT DISTRIBUTION}

Range: This greasewood shrub prairie is found in saline habitats in the northwestern Great Plains of the United States and Canada, ranging from northwestern Nebraska north to the Dakotas and Saskatchewan.

Nations: CA? US

States/Provinces: MT:S4, ND:S4?, NE:S2, SD:SU, SK?, WY:S4

USFS Ecoregions: 331D:CC, 331F:CC, 331G:CC, 342A:CC, 342F:CC, 342G:CC, M332B:CC, M332D:CC, M332E:CC

\section{ELEMENT SOURCES}

Authors: J. Drake, WCS Confidence: 1 Identifier: CEGL001508 
References: Brown 1971, Dodd and Coupland 1966, Earth Resource Technology n.d., Fisser et al. 1965, Hamner 1964, Hansen and Hoffman 1988, Hansen et al. 1984, Hirsch 1985, Johnston 1987, Jones and Walford 1995, Montana Natural Heritage Program (MTNHP) 1988, Mueggler and Stewart 1978, Mueggler and Stewart 1980, Olson and Gerhart 1982, Steinauer and Rolfsmeier 2000, Thilenius et al. 1995, U.S. Forest Service (USFS) 1992, Von Loh et al. 1999 


\section{Literature Cited}

Aldous, A. E., and H. L. Shantz. 1924. Types of vegetation in the semiarid portion of the United States and their economic significance. Journal of Agricultural Research 28(2):99-128.

Badaracco, R. J. 1971. An interpretive resource analysis of Pawnee Buttes, Colorado. Unpublished dissertation. Colorado State University, Fort Collins. 341 pp.

Baker, W. L. 1983c. Natural vegetation of part of northwestern Moffat County, Colorado. Unpublished report prepared for the State of Colorado Natural Areas Program, Department of Natural Resources, Denver by Colorado Natural Heritage Inventory, Denver.

Baker, W. L. 1984a. A preliminary classification of the natural vegetation of Colorado. Great Basin Naturalist 44(4):647-676.

Baker, W. L., and S. C. Kennedy. 1985. Presettlement vegetation of part of northwestern Moffat County, Colorado, described from remnants. Great Basin Naturalist 45(4):747-777.

Barbour, M. G., and J. Major, editors. 1977. Terrestrial vegetation of California. John Wiley and Sons, New York. 1002 pp.

Barnes, P. W., and L. L. Tieszen. 1978. A phytosociological study of 14 selected communities at the Samuel H. Ordway Prairie. Unpublished Paper. Undergraduate Research Project, Augustana College, Sioux Falls, SD.

Bear Creek Uranium Mine Application. No date. Unpublished report No. 399 prepared for Wyoming Department of Environmental Quality, Land Quality Division, Cheyenne, WY.

Blackburn, W. H., P. T. Tueller, and R. E. Eckert, Jr. 1969. Vegetation and soils of the Coils Creek Watershed. Nevada Agricultural Experiment Station Bulletin R-48. Reno. 81 pp.

Blackburn, W. H., P. T. Tueller, and R. E. Eckert, Jr. 1969c. Vegetation and soils of the Churchill Canyon Watershed. Nevada Agricultural Experiment Station Bulletin R-45. Reno. 157 pp.

Blackburn, W. H., P. T. Tueller, and R. E. Eckert, Jr. 1969d. Vegetation and soils of the Pine and Mathews Canyon Watersheds. Nevada Agricultural Experiment Station Bulletin R-46. Reno. 111 pp.

Blackburn, W. H., P. T. Tueller, and R. E. Eckert, Jr. 1971. Vegetation and soils of the Rock Springs Watershed. Nevada Agricultural Experiment Station Bulletin R-83. Reno. 116 pp.

Bonham, C. D., and R. T. Ward. 1970. Phytosociological relationships in alpine tufted hairgrass ( Deschampsia caespitosa\$ (L.) Beauv.) meadows. Arctic and Alpine Research 2(4):267-275.

Borgais, D. 1990. Unpublished data from Roundtop Butte Preserve. Data on file at Oregon Natural Heritage Program, Portland, OR.

Boutton, T. W., A. T. Harrison, and B. N. Smith. 1980. Distribution of biomass of species differing in photosynthetic pathway along an altitudinal transect in southwestern Wyoming grasslands. Oecologia 45:287-298.

Branson, F. A., and J. B. Owen. 1970. Plant cover, runoff, and sediment yield relationships on Mancos shale in western Colorado. Water Resources Research 6:783-790.

Branson, F. A., R. F. Miller, and I. S. McQueen. 1961. Soil-water availability and use by grasslands on adjacent stony and shale-derived soils in Colorado. Short papers in geologic and hydrologic sciences. U.S. Geological Survey Professional Paper 424C:251-253.

Branson, F. A., R. F. Miller, and I. S. McQueen. 1964. Effects of two kinds of geologic materials on plant communities and soil moisture. American Society of Agronomy Special Publication 5:165-175.

Branson, F. A., R. F. Miller, and I. S. McQueen. 1965. Plant communities and soil moisture relationships near Denver, Colorado. Ecology 46(3):311-319. 
Branson, F. A., R. F. Miller, and I. S. McQueen. 1976. Moisture relationships in twelve northern desert shrub communities near Grand Junction, Colorado. Ecology 57:1104-1124.

Briggs, G. M., and J. A. MacMahon. 1983. Alpine and subalpine wetland plant communities of the Uinta Mountains, Utah. Great Basin Naturalist 43(4):523-530.

Brotherson, J. D. 1987. Plant community zonation in response to soil gradients in a saline meadow near Utah Lake, Utah County, Utah. Great Basin Naturalist 47(2):322-333.

Brotherson, J. D., and S. J. Barnes. 1984. Habitat relationships of Glaux maritima\$ in central Utah. Great Basin Naturalist 44(2):299-309.

Brotherson, J. D., L. L. Rasmussen, and R. D. Black. 1986. Comparative habitat and community relationships of $\sim$ Atriplex confertifolia\$ and Sarcobatus vermiculatus\$ in central Utah. Great Basin Naturalist 46(2):348357.

Brown, D. E., editor. 1982. Biotic communities of the American Southwest-United States and Mexico. Desert Plants Special Issue 4(1-4):1-342.

Brown, R. W. 1971. Distribution of plant communities in southeastern Montana badlands. The American Midland Naturalist 85(2):458-477.

Buckner, D. L. 1977. Ribbon forest development and maintenance in the central Rocky Mountains of Colorado. Unpublished dissertation. University of Colorado, Boulder. 224 pp.

Bujakiewicz, A. 1975. Vegetational zonation in the Front Range of the Rocky Mountains, Colorado. USA. Fragmenta Floristica et Geobotanica 21:99-142.

Bundy, R. M., J. V. Baumgartner, M. S. Reid, P. S. Bourgeron, H. C. Humphries, and B. L. Donohue. 1996. Ecological classification of wetland plant associations in the Lahontan Valley, Nevada. Prepared for Stillwater National Wildlife Refuge and USDI Fish \& Wildlife Service. 53 pp. not including inventories, tables and graphs.

Bunin, J. E. 1985. Vegetation of the City of Boulder, Colorado open space lands. Report prepared for the City of Boulder, Real Estate/Open Space, Boulder, CO. 114 pp.

Cacek, T. L. 1973. An ecological interpretation of north central Colorado. Unpublished dissertation. Colorado State University, Fort Collins. 261 pp.

Chappell, C., R. Crawford, J. Kagan, and P. J. Doran. 1997. A vegetation, land use, and habitat classification system for the terrestrial and aquatic ecosystems of Oregon and Washington. Unpublished report prepared for Wildlife habitat and species associations within Oregon and Washington landscapes: Building a common understanding for management. Prepared by Washington and Oregon Natural Heritage Programs, Olympia WA, and Portland, OR. 177 pp.

Christensen, E. M., and S. L. Welsh. 1963. Presettlement vegetation of the valleys of western Summit and Wasatch counties, Utah. Proceedings of the Utah Academy of Science, Arts and Letters 40:163-174.

Clements, F. E., and G. W. Goldsmith. 1924. Climaxes and climates of the Pike's Peak region. Pages 14-16 in: The phytometer method in ecology: The plant and community as instruments. Carnegie Institute of Washington Publication No. 356.

Comer, P. (editor), L. Allen, S. Cooper, D. Faber-Langendoen, and G. Jones. 1999. Selected shrubland and grassland communities of the northern Great Plains. Report to the Nebraska National Forest. The Nature Conservancy.

Cooper, S. V., P. Lesica, R. L. DeVelice, and T. McGarvey. 1995. Classification of southwestern Montana plant communities with emphasis on those of Dillon Resource Area, Bureau of Land Management. Montana Natural Heritage Program, Helena, MT. 154 pp.

Copeland, W. N. 1979. Harney Lake RNA Guidebook, Supplement \#9. USDA Forest Service Experiment Station, Portland, OR. 
Copeland, W. N., and S. E. Greene. 1982. Stinking Lake Research Natural Area. Supplement \#12 to Franklin, J. F., F. C. Hall, C. T. Dyrness and C. Maser. 1972. Federal research natural areas in Oregon and Washington: A guidebook for scientists and educators. USDA Forest Service, Pacific Northwest Forest and Range Experiment Station, Portland, OR.

Costello, D. F. 1944. Important species of the major forage types in Colorado and Wyoming. Ecological Monographs 14:107-134.

Cotter-Ferguson Project. No date. Application No. 490, on file at Wyoming Department of Environmental Quality, Land Quality Division, Cheyenne.

Coupland, R. T. 1950. Ecology of mixed prairie in Canada. Ecological Monographs 20(4):271-315.

Coupland, R. T. 1992a. Mixed prairie. Pages 151-182 in: R. T. Coupland, editor. Natural grasslands introduction and Western Hemisphere. Ecosystems of the world, Volume 8A. Elsevier Publishing Company, Amsterdam.

Cronquist, A., A. H. Holmgren, N. H. Holmgren, J. L. Reveal, and P. K. Holmgren. 1977. Intermountain flora: Vascular plants of the Intermountain West, U.S.A. Volume 6: The Monocotyledons. Columbia University Press, New York. 584 pp.

Cross, A. F. 1991. Vegetation of two southeastern Arizona desert marshes. Madrono 38(3):185-194.

Crowe, E. A., and R. R. Clausnitzer. 1997. Mid-montane wetland plant associations of the Malheur, Umatilla, and Wallowa-Whitman national forests. USDA Forest Service, Pacific Northwest Region. Technical Paper R6NR-ECOL-TP-22-97.

Culver, D. R., and J. S. Sanderson. 1997. A Natural Heritage assessment of wetland and riparian areas in Summit County, Colorado. Report prepared for the Department of Natural Resources, Denver, CO, by Colorado Natural Heritage Program, Colorado State University, Fort Collins, CO.

Culwell, L. D., and K. L. Scow. 1982. Terrestrial vegetation inventory: Dominy Project Area, Custer County, Montana 1979-1980. Unpublished technical report for Western Energy Company by Westech, Helena, MT. 144 pp. plus 15 pp. appendix.

Dastrup, B. C. 1963. Vegetational changes of the Uinta Basin since settlement. Unpublished thesis. Brigham Young University, Provo, UT. 118 pp.

Daubenmire, R. F. 1970. Steppe vegetation of Washington. Washington State University Agricultural Experiment Station Technical Bulletin No. 62. 131 pp.

Daubenmire, R. F., and J. B. Daubenmire. 1968. Forest vegetation of eastern Washington and northern Idaho. Washington State University Agricultural Experiment Station Technical Bulletin No. 60. 104 pp.

Davis, G. V. 1959. A vegetative study of three relic areas located within Fort Laramie National Monument. Unpublished thesis. University of Wyoming, Laramie.

Dealy, J. E. 1971. Habitat characteristics of the Silver Lake mule deer range. USDA Forest Service, Pacific Northwest Forest and Range Experiment Station. Research Paper PNW-125. Portland, OR. 99 pp.

DeVelice, R. L., and P. Lesica. 1993. Plant community classification for vegetation on BLM lands, Pryor Mountains, Carbon County, Montana. Unpublished report by Montana Natural Heritage Program, Helena, MT. 78 pp.

DeVelice, R. L., J. Lichthardt, and P. S. Bourgeron. 1991. A preliminary classification of the plant communities of northeastern Montana. Prepared for the Montana Natural Heritage Program. Helena, MT. 144 pp.

DeVelice, R. L., S. V. Cooper, J. T. McGarvey, J. Lichthardt, and P. S. Bourgeron. 1995. Plant communities of northeastern Montana: A first approximation. Montana Natural Heritage Program, Helena, MT. 116 pp.

Dick-Peddie, W. A. 1986. Draft manuscript for book on vegetation of New Mexico to be published by University of New Mexico Press. 
Dick-Peddie, W. A. 1993. New Mexico vegetation: Past, present, and future. University of New Mexico Press, Albuquerque. 244 pp.

Dodd, J. D., and R. T. Coupland. 1966. Vegetation of saline areas in Saskatchewan. Ecology 47(6):958-968.

Donart, G. B., D. Sylvester, and W. Hickey. 1978a. A vegetation classification system for New Mexico, USA. Pages 488-490 in: Rangeland Congress, Denver, CO, 14-18 August 1978. Society for Range Management, Denver.

Durkin, P., M. Bradley, E. Muldavin, and P. Mehlhop. 1994. A riparian/wetland vegetation community classification of New Mexico: Pecos River Basin. Unpublished report for New Mexico Environment Department Surface Water Quality Bureau.

Durkin, P., M. Bradley, E. Muldavin, and P. Mehlhop. 1995. Riparian/wetland vegetation community classification of Rio Grande: A classification and site evaluation. Unpublished report for New Mexico Environment Department Surface Water Quality Bureau. New Mexico Natural Heritage Program, Albuquerque.

Earth Resource Technology. No date. Vanguard II Mine Application No. 334-T2, on file at Wyoming Department of Environmental Quality, Land Quality Division, Cheyenne.

Ellis, S. L., T. Shoemaker, and R. Sanz. 1979. Inventories of plants birds, mammals, reptiles, and amphibians of the Unaweep Canyon Springs, Mesa County, Colorado. Unpublished report prepared for Colorado Natural Areas Program, Department of Natural Resources, Denver.

Faber-Langendoen, D., and Midwest State Natural Heritage Program Ecologists. 1996. Terrestrial vegetation of the midwest United States. International classification of ecological communities: Terrestrial vegetation of the United States. The Nature Conservancy, Arlington, VA.

Fenemore, R. M., Jr. 1970. Plant succession in a receding lake bed in the western Great Basin. Unpublished thesis. University of Nevada, Reno.

Fire Effects Information System (FEIS). 1998. USDA Forest Service. URL http://www.fs.fed.us/database/feis/.

Fisser, H. G., J. R. Wight, J. R. Flesland, and L. D. Robinson. 1965. Halogeton research, 1964 results. University of Wyoming Cooperative Research Report to the USDI Bureau of Land Management, Sections I-VI. Wyoming Agricultural Experiment Station. Mimeographed Circular pages 1-82. University of Wyoming, Laramie.

Flowers, S. 1962. Vegetation of Morrow Point and Blue Mesa Reservoir basins of the upper Gunnison River, Colorado. Pages 47-102 in: A. M. Woodbury, editor. Ecological studies of the flora and fauna of the Curecanti Reservoir Basins, western Colorado. University of Utah, Anthropological Papers No. 59 (Upper Colo. Series No. 8).

Francis, R. E. 1986. Phyto-edaphic communities of the Upper Rio Puerco Watershed, New Mexico. USDA Forest Service, Rocky Mountain Forest and Range Experiment Station. Research Paper RM-272. Fort Collins, CO. 73 pp.

Franklin, J. F., and C. T. Dyrness. 1973. Natural vegetation of Oregon and Washington. USDA Forest Service, Pacific Northwest Forest and Range Experiment Station. General Technical Report PNW-8. Portland, OR. 417 pp.

Godfread, C. 1994. The vegetation of the Little Missouri Badlands of North Dakota. Pages 17-24 in: Proceedings of the Leafy Spurge Strategic Planning Workshop, March 29-30, Dickinson, ND.

Graham, E. H. 1937. Botanical studies in the Uinta Basin of Utah and Colorado. Annals of the Carnegie Museum 26:28-432. 
Hadley, R. F., and F. A. Branson. 1965. Surficial geology and microclimatic effects on vegetation, soils and geomorphology in the Denver, Colorado, area. Pages 56-63 in: Guidebook for 1-day field conferencesBoulder area, CO. 7th International Association for Quaternary Research Congress. Nebraska Academy of Science.

Hall, F. C. 1973. Plant communities of the Blue Mountains in eastern Oregon and southeastern Washington. USDA Forest Service, Pacific Northwest Region. R6 Area Guide 3-1. 62 pp.

Hall, H. H. 1971. Ecology of a subalpine meadow of the Aquarius Plateau, Garfield and Wayne counties, Utah. Unpublished dissertation. Brigham Young University, Provo, UT.

Hamann, M. J. 1972. Vegetation of alpine and subalpine meadows of Mount Rainier National Park, Washington. Unpublished thesis. Washington State University, Pullman. 120 pp.

Hamner, R. W. 1964. An ecological study of $\sim$ Sarcobatus vermiculatus\$ communities of the Big Horn Basin, Wyoming. Unpublished thesis. University of Wyoming, Laramie.

Hansen, P. L. 1985. An ecological study of the vegetation of the Grand River/Cedar River, Sioux, and Ashland districts of the Custer National Forest. Unpublished dissertation. South Dakota State University. 257 pp.

Hansen, P. L., and G. R. Hoffman. 1988. The vegetation of the Grand River/Cedar River, Sioux, and Ashland districts of the Custer National Forest: A habitat type classification. USDA Forest Service, Rocky Mountain Forest and Range Experiment Station. General Technical Report RM-157. Fort Collins, CO. 68 pp.

Hansen, P. L., G. R. Hoffman, and A. J. Bjugstad. 1984. The vegetation of Theodore Roosevelt National Park, North Dakota: A habitat type classification. USDA Forest Service, Rocky Mountain Forest and Range Experiment Station. General Technical Report RM-113. Fort Collins, CO. 35 pp.

Hansen, P. L., R. D. Pfister, K. Boggs, B. J. Cook, J. Joy, and D. K. Hinckley. 1995. Classification and management of Montana's riparian and wetland sites. Montana Forest and Conservation Experiment Station, School of Forestry, University of Montana, Miscellaneous Publication No. 54. 646 pp.

Hansen, P. L., S. W. Chadde, and R. D. Pfister. 1988. Riparian dominance types of Montana. University of Montana Miscellaneous Publication 49. Montana Forest and Conservation Experiment Station, Missoula. $411 \mathrm{pp}$.

Hansen, P., K. Boggs, and R. Pfister. 1991. Classification and management of riparian and wetland sites in Montana. Unpublished draft version prepared for Montana Riparian Association, Montana Forest and Conservation Experiment Station, School of Forestry, University of Montana, Missoula. 478 pp.

Hansen, P., S. Chadde, R. Pfister, J. Joy, D. Svoboda, J. Pierce, and L. Myers. 1988a. Riparian site types, habitat types, and community types of southwestern Montana. Draft Version 1. Montana Riparian Association, Missoula.

Hanson, H. C. 1929. Range resources of the San Luis Valley. Pages 5-61 in: Range resources of the San Luis Valley. Bulletin 335. Colorado Experiment Station, Fort Collins, CO.

Hanson, H. C. 1955. Characteristics of the Stipa comata - Bouteloua gracilis - Bouteloua curtipendula\$ association in northern Colorado. Ecology 36(2):269-280.

Hanson, H. C. 1957. The use of basic principles in the classification of range vegetation. Journal of Range Management 10:26-33.

Hanson, H. C., and E. Dahl. 1956. Some grassland communities in the mountain-front zone in northern Colorado. Vegetatio 7:249-270.

Hanson, H. C., and W. S. Ball. 1928. An application of Raunkiaer's law of frequence to grazing studies. Ecology 9:467-473.

Hanson, H. C., and W. Whitman. 1938. Characteristics of major grassland types in western North Dakota. Ecological Monographs 8:58-114. 
Hanson, H. C., L. D. Love and M. S. Morris. 1931. Effects of different systems of grazing by cattle upon a western wheat grass type of range near Fort Collins, Colorado. Colorado Agricultural Experiment Station Bulletin 377. 82 pp.

Hardy Ranch Mine Application. No date. No. 492, on file at Wyoming Department of Environmental Quality, Land Quality Division, Cheyenne.

Hendrickson, D. A., and W. L. Minckley. 1984. Cienegas - Vanishing climax communities of the American Southwest. Desert Plants 6(3):131-175.

Hermann, F. J. 1970. Manual of the Carices of the Rocky Mountains and Colorado Basin. Agriculture Handbook No. 374. USDA Forest Service, Washington, DC. 397 pp.

Hess, K. 1981. Phyto-edaphic study of habitat types of the Arapaho-Roosevelt National Forest, Colorado. Unpublished dissertation. Colorado State University, Fort Collins. 558 pp.

Hess, K., and C. H. Wasser. 1982. Grassland, shrubland, and forest habitat types of the White River-Arapaho National Forest. Unpublished final report 53-82 FT-1-19. USDA Forest Service, Rocky Mountain Forest and Range Experiment Station. Fort Collins, CO. 335 pp.

Hirsch, K. J. 1985. Habitat type classification of grasslands and shrublands of southwestern North Dakota. Ph.D. thesis. North Dakota State University, Fargo.

Holland, R. F. 1986. Preliminary descriptions of the terrestrial natural communities of California. Unpublished report prepared for the California Department of Fish and Game, Nongame-Heritage Program and Natural Diversity Database, Sacramento. 156 pp.

Hubbard, W. A. 1950. The climate, soils, and soil-plant relationships of an area in southwestern Saskatchewan. Sci. Agric. 30(8):327-342.

Hyder, D. N., R. E. Bement, E. E. Remmenga, and C. Terwilliger, Jr. 1966. Vegetation-soils and vegetationgrazing relations from frequency data. Journal of Range Management 19:11-17.

Johnson, C. G., and S. A. Simon. 1985. Plant associations of the Wallowa Valley Ranger District, Part II: Steppe. USDA Forest Service, Pacific Northwest Region, Wallowa-Whitman National Forest. 258 pp.

Johnson, C. G., Jr., and S. A. Simon. 1987. Plant associations of the Wallowa-Snake Province Wallowa-Whitman National Forest. USDA Forest Service, Pacific Northwest Region, Wallowa-Whitman National Forest. Technical Paper R6-ECOL-TP-255A-86. 399 pp. plus appendices.

Johnson, W. M. 1961b. The ecology of alpine and subalpine ranges in Wyoming as related to use by big game and domestic sheep. Unpublished dissertation. University of Wyoming, Laramie.

Johnston, B. C. 1987. Plant associations of Region Two: Potential plant communities of Wyoming, South Dakota, Nebraska, Colorado, and Kansas. R2-ECOL-87-2. USDA Forest Service, Rocky Mountain Region. Lakewood, CO. 429 pp.

Jones, G. 1992. Wyoming plant community classification (Draft). Wyoming Natural Diversity Database, Laramie, WY. 183 pp.

Jones, G. P., and G. M. Walford. 1995. Major riparian vegetation types of eastern Wyoming. Submitted to Wyoming Department of Environmental Quality, Water Quality Division. Wyoming Natural Diversity Database, Laramie, WY. 245 pp.

Kagan, J. S. 1986. Status report for $\sim$ Thelypodium howellii subsp. spectabilis\$. Oregon Natural Heritage Data Base, The Nature Conservancy, Portland.

Kahler, L. J. 1973. Correlation of slope exposure with differences in the composition of the vegetation community at 7000 feet in Clear Creek Canyon west of Golden, Colorado. Unpublished thesis. University of Colorado, Boulder. 105 pp. 
Kartesz, J. T. 1994. A synonymized checklist of the vascular flora of the United States, Canada, and Greenland. Second edition. Volume 1--Checklist. Timber Press, Portland, OR. 622 pp.

Keammerer, W. R., and R. E. Stoecker. 1975. Vegetation and wildlife studies along proposed corridors for oil shale tract C-b. Unpublished report prepared for Shell Oil Co., Denver, by Stoecker-Keammerer and Associates, Boulder, CO. 86 pp.

Kettler, S., and A. McMullen. 1996. Routt National Forest riparian vegetation classification. Report prepared for Routt National Forest by the Colorado Natural Heritage Program, Colorado State University, Fort Collins.

Kittel, G. M., and N. D. Lederer. 1993. A preliminary classification of the riparian vegetation of the Yampa and San Miguel/Dolores river basins. Unpublished report prepared for Colorado Department of Health and the Environmental Protection Agency by The Nature Conservancy, Colorado Field Office, Boulder.

Kittel, G., E. Van Wie, and M. Damm. 1997. A classification of the riparian vegetation of the South Platte Basin (and part of Republican River Basin), Colorado. Submitted to Colorado Department of Natural Resources and the Environmental Protection Agency, Region VIII. Prepared by Colorado Natural Heritage Program, Colorado State University, Fort Collins.

Kittel, G., E. Van Wie, M. Damm, R. Rondeau, S. Kettler, and J. Sanderson. 1999. A classification of the riparian plant associations of the Rio Grande and Closed Basin watersheds, Colorado. Unpublished report prepared by the Colorado Natural Heritage Program, Colorado State University, Fort Collins.

Kittel, G., R. Rondeau, N. Lederer, and D. Randolph. 1994. A classification of the riparian vegetation of the White and Colorado River basins, Colorado. Final report submitted to Colorado Department of Natural Resources and the Environmental Protection Agency. Colorado Natural Heritage Program, Boulder. 166 pp.

Kovalchik, B. L. 1987. Riparian zone associations - Deschutes, Ochoco, Fremont, and Winema national forests. USDA Forest Service Technical Paper 279-87. Pacific Northwest Region, Portland, OR. 171 pp.

Kovalchik, B. L. 1993. Riparian plant associations on the national forests of eastern Washington - Draft version 1. USDA Forest Service, Colville National Forest, Colville, WA. 203 pp.

Kuchler, A. W. 1964. Potential natural vegetation of the conterminous United States. American Geographic Society Special Publication 36. 116 pp.

Lauenroth, W. K., D. G. Milchunas, J. D. Dodd, R. H. Hart, R. K. Heitschidt, and L. R. Rittenhouse. 1994. Effects of grazing on ecosystems of the Great Plains. Pages 69-100 in : M. Vavra, W. A. Laycock, and R. D. Pieper, editors. Ecological implications of livestock herbivory in the west. Society for Range Management, Denver, CO.

Lesica, P., and R. L. DeVelice. 1992. Plant communities of the Pryor Mountains. Preliminary report prepared by the Montana Natural Heritage Program, Helena, MT.

Livingston, R. B. 1947. An ecological study of the Black Forest region and adjacent plains. Unpublished dissertation. Duke University, Durham, NC. 134 pp.

Looman, J. 1980. The vegetation of the Canadian prairie provinces. II. The grasslands, Part 1. Phytocoenologia 8(2):153-190.

Manning, M. 1988. Ecology and rooting characteristics of four intermountain meadow community types. Unpublished thesis. University of Nevada, Reno.

Manning, M. E., and W. G. Padgett. 1991. Riparian community type classification for the Humboldt and Toiyabe National Forests, Nevada and eastern California. Unpublished draft report prepared for USDA Forest Service, Intermountain Region Ecology and Classification Program, Ogden, UT. 490 pp.

Manning, M. E., and W. G. Padgett. 1995. Riparian community type classification for Humboldt and Toiyabe national forests, Nevada and eastern California. USDA Forest Service, Intermountain Region. 306 pp. 
Marr, J. W., and D. L. Buckner. 1974. Colorado to Wyoming pipeline corridor study. Unpublished report for Colony Development Operation, Atlantic Richfield Co., Denver by Thorne Ecological Institute, Boulder, CO. 79 pp.

Medicine Bow Mine Application. No date. Application No. 331-T1, on file at Wyoming Department of Environmental Quality, Land Quality Division, Cheyenne.

Moir, W. H. 1969. Steppe communities in the foothills of the Colorado Front Range and their relative productivities. The American Midland Naturalist 81(2):331-340.

Montana Natural Heritage Program. 1988. Draft guide to the natural vegetation of Montana. Montana Natural Heritage Program, Helena. 389 pp.

Mueggler, W. F., and W. L. Stewart. 1978. Grassland and shrubland habitat types of western Montana. USDA Forest Service. General Technical Report INT-66. Ogden, UT. 154 pp.

Mueggler, W. F., and W. L. Stewart. 1980. Grassland and shrubland habitat types of western Montana. USDA Forest Service, General Technical Report INT-66. Intermountain Forest and Range Experiment Station. Ogden, UT. 154 pp.

Mueggler, W. F., and W. L. Stewart. 1980. Grassland and shrubland habitat types of western Montana. USDA Forest Service. General Technical Report INT-66. Intermountain Forest and Range Experiment Station, Ogden, UT. 154 pp.

Muldavin, E., and P. Mehlhop. 1992. A preliminary classification and test vegetation map for White Sands Missile Range and San Andreas National Wildlife Refuge, New Mexico. University of New Mexico, New Mexico Natural Heritage Program.

Mutel, C. F. 1973. An ecological study of the plant communities of certain montane meadows in the Front Range of Colorado. Unpublished thesis. University of Colorado, Boulder. $77 \mathrm{pp}$.

Mutel, C. F. 1976. From grassland to glacier: An ecology of Boulder County, Colorado. Johnson Publishing Company, Boulder. 169 pp.

Mutel, C., and J. W. Marr. 1973. A vegetative study of three montane herbaceous basins. Journal of the ColoradoWyoming Academy of Science 7(4):28. (Abstract)

Mutz, K. M., and J. Queiroz. 1983. Riparian community classification for the Centennial Mountains and South Fork Salmon River, Idaho. Unpublished report prepared for USDA Forest Service Intermountain Region under contract 53-84M8-2-0048 by Meiiji Resource Consultants, Layton, UT. 168 pp.

Nelson, J. R. 1961. Woody plant communities in the badlands of western North Dakota. Proceedings of the North Dakota Academy of Science 15:42-44.

Olson, R. A., and W. A. Gerhart. 1982. A physical and biological characterization of riparian habitat and its importance to wildlife in Wyoming. Unpublished report prepared for Wyoming Fish and Game Department, Cheyenne, WY. 188 pp.

Oregon Natural Heritage Program. No date. Unpublished data files. Oregon Natural Heritage Program, The Nature Conservancy, Portland, OR.

Padgett, W. G. 1982. Ecology of riparian plant communities in southern Malheur National Forest. Unpublished thesis. Oregon State University, Corvallis. 143 pp.

Padgett, W. G., A. P. Youngblood, and A. H. Winward. 1988b. Riparian community type classification of Utah. USDA Forest Service, Intermountain Region Publication R4-ECOL-88-01. Ogden, UT.

Padgett, W. G., A. P. Youngblood, and A. H. Winward. 1989. Riparian community type classification of Utah and southeastern Idaho. USDA Forest Service, Intermountain Region. Report R4-ECOL-89-01. Ogden, UT. 191 pp.

Ramaley, F. 1916. Dry grassland of a high mountain park in northern Colorado. The Plant World 19(4):249-270. 
Ramaley, F. 1919. Some mountain plant communities of sandy soil. The Plant World 22(11):313-329.

Ramaley, F. 1919a. The role of sedges in some Colorado plant communities. American Journal of Botany 6:120130.

Ramaley, F. 1927. Colorado plant life. University of Colorado Semicentennial series 1877-1927. Volume II. 299 pp.

Ramaley, F. 1942. Vegetation of the San Luis Valley in southern Colorado. University of Colorado Studies, Series D, 1:231-277.

Redmann, R. E. 1972. Plant communities and soils of an eastern North Dakota prairie. Bulletin of the Torrey Botanical Club 99(2):65-76.

Reid, M. S., L. S. Engelking, and P. S. Bourgeron. 1994. Rare plants communities of the conterminous United States, Western Region. Pages 305-620 in: D. H. Grossman, K. L. Goodin, and C. L Reuss, editors. Rare plant communities of the conterminous United States, a initial survey. The Nature Conservancy, Arlington, VA.

Reid, W. H. 1974. Analysis of plant ecological systems through simulation of individual organisms. Unpublished dissertation. University of Colorado, Boulder. 265 pp.

Richard, C., G. Kittel, and S. Kettler. 1996. A Classification of the Riparian Vegetation of the San Juan National Forest. Draft 1 report. Colorado Natural Heritage Program, Colorado State University, Fort Collins.

Rogers, C. M. 1950a. The vegetation of the Mesa de Maya region of Colorado, New Mexico, and Oklahoma. Botany _ :16-17.

Sanderson, J., and S. Kettler. 1996. A preliminary wetland vegetation classification for a portion of Colorado's west slope. Report prepared for Colorado Department of Natural Resources, Denver, CO, and U.S. Environmental Protection Agency, Region VIII, Denver, CO. Colorado Natural Heritage Program, Ft. Collins, CO. 243 pp.

Sarr, D. 1995. Grazing, graminoids, and hysteresis: Exploring relationships between livestock production, riparian communities, and ecosystem recovery in the southern Sierra Nevada, California. Unpublished M.A. thesis. University of California, Santa Barbara. 167 pp.

Sawyer, J. O., and T. Keeler-Wolf. 1995. A manual of California vegetation. California Native Plant Society, Sacramento. $471 \mathrm{pp}$.

Shanks, D. L. 1977. Aerial photo densitometry for rangeland planning and evaluation. Unpublished thesis. Colorado State University, Fort Collins. 66 pp.

Shantz, H. L. 1906. A study of the vegetation of the mesa region east of Pike's Peak, the $\sim$ Bouteloua \$ formation. II. Development of the formation. Botanical Gazette 42:179-207.

Shantz, H. L. 1911. Natural vegetation as an indicator of the capabilities of land for crop production in the Great Plains area. USDA Bureau of Plant Industry Bulletin 201. 100 pp.

Shantz, H. L. 1923. The natural vegetation of the Great Plains region. Annals of the Association of American Geographers 13:81-107.

Shupe, J. B., J. D. Brotherson, and S. R. Rushforth. 1986. Patterns of vegetation surrounding springs in Goshen Bay, Utah County, Utah, U.S.A. Hydrobiologia 139:97-107.

Smoliak, S. 1965. A comparison of ungrazed and lightly grazed Stipa-Bouteloua \$ prairie in southeastern Alberta. Canadian Journal of Plant Science 45:270-275.

Smoliak, S. J., J. F. Dormaar, and A. Johnston. 1972. Long-term grazing effects on $\sim$ Stipa-Bouteloua $\$$ prairie soils. Journal of Range Management 25:246-251.

Soil Conservation Service. 1978. Range site descriptions for Colorado. Technical Guide, Section II-E. USDA Soil Conservation Service, Colorado State Office, Denver. 
Stearns-Roger, Inc. 1978. Rawhide Energy Project. Transmission system, ecological investigations. Volume II. Technical baseline report to Platte River Power Authority. 51 pp.

Steinauer, G., and S. Rolfsmeier. 2000. Terrestrial natural communities of Nebraska (January 2000 version). Unpublished report of the Nebraska Game and Parks Commission. Lincoln, NE. 143 pp.

Stewart, B. K. 1940. Plant ecology and paleoecology of the Creede Valley, Colorado. Unpublished dissertation. University of Colorado, Boulder. 154 pp.

Stoecker-Keammerer Consultants. No date (a). Black Thunder Mine Application No. 233-T3, on file at Wyoming Department of Environmental Quality, Land Quality Division, Cheyenne.

Stoecker-Keammerer Consultants. No date (b). Coal Creek Mine Application No. 483-T1, on file at Wyoming Department of Environmental Quality, Land Quality Division, Cheyenne.

Sturges, D. L. 1968. Hydrologic properties of peat from a Wyoming mountain bog. Soil Science 106:262-264.

Sweetwater Uranium Project. 1978. Application No. 481, on file at Wyoming Department of Environmental Quality, Land Quality Division, Cheyenne.

Terwilliger, C., Jr., and E. L. Smith. 1978. Range resource types in North Park, Colorado. Colorado State University Range Science Department Science Series 32. 48 pp.

Terwilliger, C., Jr., K. Hess, and C. H. Wasser. 1979. The habitat types of Region II, USDA Forest Service: A preliminary list and description. Unpublished initial progress report for Habitat Type Classification, Region 2, USDA Forest Service.

Thilenius, J. F., and G. R. Brown. 1990. Vegetation on semi-arid rangelands, Cheyenne River Basin, Wyoming. Unpublished report prepared for USDA Forest Service, Rocky Mountain Forest and Range Experiment Station, Laramie, WY. 147 pp.

Thilenius, J. F., G. R. Brown, and A. L. Medina. 1995. Vegetation on semi-arid rangelands, Cheyenne River Basin, Wyoming. USDA Forest Service. General Technical Report RM-GTR-263. Rocky Mountain Forest and Range Experiment Station, Fort Collins, CO. 60 pp.

Tiedemann, A. 1972. Soil properties and nutrient availability in tarweed communities of central Washington. Journal of Range Management 25(6):438-443.

Tolstead, W. L. 1941. Plant communities and secondary succession in south-central South Dakota. Ecology 22(3):322-328.

Tolstead, W. L. 1942. Vegetation of the northern part of Cherry County, Nebraska. Ecological Monographs 12(3):257-292.

Trammell, V. M., and J. R. Trammell, Jr. 1977. Plant communities of Roxborough Park, Douglas County, Colorado. Unpublished report prepared by Arapahoe Community College, Littleton, CO. 14 pp.

Tuhy, J. S., and S. Jensen. 1982. Riparian classification for the Upper Salmon and Middle Fork Salmon River drainages, Idaho. Unpublished report prepared for the USDA Forest Service, Intermountain Region by White Horse Associates, Smithfield, UT. 183 pp.

Tweit, S., and K. Houston. 1980. Grassland and shrubland habitat types of the Shoshone National Forest. USDA Forest Service, Rocky Mountain Region, Shoshone National Forest.

U.S. Forest Service. 1992. Draft habitat types of the Little Missouri National Grasslands. Medora and McKenzie ranger districts, Custer National Forest. Dickinson, ND.

Ungar, I. A. 1967. Vegetation-soil relationships on saline soils in northern Kansas. The American Midland Naturalist 78(1):98-121.

Ungar, I. A., W. Hogan, and M. McClennand. 1969. Plant communities of saline soils at Lincoln, Nebraska. The American Midland Naturalist 82(2):564-577. 
Vestal, A. G. 1913. Plains vegetation adjoining the mountains: The region about Boulder in Colorado. Unpublished thesis. University of Colorado, Boulder. 40 pp.

Vestal, A. G. 1914. Prairie vegetation of a mountain-front area in Colorado. Botanical Gazette 58(5):377-400.

Vestal, A. G. 1919. Phytogeography of the eastern mountain front in Colorado. I. Physical geography and distribution of vegetation. Botanical Gazette 68(3):153-193.

Von Loh, J., D. Cogan, D. Faber-Langendoen, D. Crawford, and M. Pucherelli. 1999. USGS-NPS Vegetation Mapping Program, Badlands National Park, South Dakota. USDI Bureau of Reclamation. Technical Memorandum No. 8260-99-02. Denver, CO.

Walford, G. M. 1996. Statewide classification of riparian and wetland dominance types and plant communities Bighorn Basin segment. Report submitted to the Wyoming Department of Environmental Quality, Land Quality Division by the Wyoming Natural Diversity Database. 185 pp.

Walford, G., G. Jones, W. Fertig, and K. Houston. 1997. Riparian and wetland plant community types of the Shoshone National Forest. Unpublished report. Wyoming Natural Diversity Database for The Nature Conservancy, and the USDA Forest Service. Wyoming Natural Diversity Database, Laramie. 227 pp.

Warren, A. No date. Range site descriptions in Divide Resource Area. Unpublished report prepared for USDI Bureau of Land Management, Great Divide Resource Area, Rawlins, WY.

Weaver, J. E., and F. W. Albertson. 1956. Grasslands of the Great Plains: Their nature and use. Johnsen Publishing Co., Lincoln, NE. 395 pp.

West, N. E. 1983b. Intermountain salt desert shrublands. Pages 375-397 in: N. E. West, editor. Temperate deserts and semi-deserts. Ecosystems of the world, Volume 5. Elsevier Publishing Company, Amsterdam.

Western Resources Development Corporation. No date (a). North Antelope Mine Application No. 532-T2. On file at Wyoming Department of Environmental Quality, Land Quality Division, Cheyenne.

Winward, A. H. 1980. Taxonomy and ecology of sagebrush in Oregon. Oregon State University Agricultural Experiment Station Bulletin 642:1-15.

Wooten, S. A. 1980. Vegetation recovery following disturbance on the Central Plains Experimental Range. Unpublished thesis. Colorado State University, Fort Collins.

Young, J. A., R. A. Evans, B. A. Roundy, and J. A. Brown. 1986. Dynamic landforms and plant communities in a pluvial lake basin. Great Basin Naturalist 46(1):1-21.

Youngblood, A. P., W. G. Padgett, and A. H. Winward. 1985a. Riparian community type classification of eastern Idaho-western Wyoming. USDA Forest Service, Intermountain Region. R4-Ecol-85-01. Ogden, UT. 78 pp.

Youngblood, A. P., W. G. Padgett, and A. H. Winward. 1985b. Riparian community type classification of northern Utah and adjacent Idaho. Unpublished report prepared for USDA Forest Service, Intermountain Region, Ogden, UT. 104 pp. 